\title{
LA NEGACIÓN O JUSTIFICACIÓN DEL GENOCIDIO COMO DELITO EN EL DERECHO EUROPEO. UNA PROPUESTA A LA LUZ DE LA RECOMENDACIÓN N.$^{\circ} 15$ DE LA ECRI
}

MARÍA ELÓSEGUI ITXASO 
SUMARIO

I. INTRODUCCIÓN. II. EL DERECHO Y SU RELACIÓN CON LA HISTORIA: RELACIONES Y DIFERENCIAS. EL NEGACIONISMO SIMPLE O NEUTRAL FRENTE AL NEGACIONISMO CUALIFICADO. III. EL NEGACIONISMO REVISIONISTA NO DEBERÍA ESTAR PROTEGIDO POR EL DERECHO A LA LIBERTAD DE EXPRESIÓN Y DE INVESTIGACIÓN. IV. LA DEFINICIÓN DE GENOCIDIO EN LOS INSTRUMENTOS DE NACIONES UNIDAS Y LA DIFERENCIA CON LOS CRÍMENES CONTRA LA HUMANIDAD. V. LA NORMATIVA DE LA UE. VI. LA NORMATIVA DEL CONSEJO DE EUROPA. EL CONVENIO SOBRE CIBERCRIMINALIDAD RELATIVO A LA PENALIZACIÓN DE ACTOS DE NATURALEZA RACISTA Y XENÓFOBA COMETIDOS A TRAVÉS DE SISTEMAS INFORMÁTICOS Y SU PROTOCOLO ADICIONAL. VII. ALGUNOS PROBLEMAS DE INTERPRETACIÓN DE LA LEGISLACIÓN DEL CONSEJO DE EUROPA Y DE LA UE. LA NO EXIGENCIA DE DEMOSTRAR LA INTENCIÓN RACISTA EN EL CONVENIO SOBRE CIBERCRIMINALIDAD DEL CONSEJO DE EUROPA. VIII. LA PRUEBA DE LA INTENCIÓN RACISTA. IX. EL REQUISITO DE INTENCIÓN RACISTA Y DE PUBLICIDAD EN LA RECOMENDACIÓN N. ${ }^{\circ} 7$ DE LA ECRI. X. LA DEFINICIÓN DE NEGACIONISMO COMO UNA FORMA DE DISCURSO DEL ODIO EN LA RECOMENDACIÓN N. ${ }^{\circ} 15$ DE LA ECRI. XI. EL CRITERIO SENTADO POR EL TEDH: EL DEBATE LEGÍTIMO DE IDEAS Y LOS HECHOS HISTÓRICOS CLARAMENTE ESTABLECIDOS. XII. EL TRIBUNAL EUROPEO DE DERECHOS HUMANOS, LA LIBERTAD DE EXPRESIÓN Y SUS LÍMITES. XIII. EL ARTÍCULO 17 DEL CONVENIO Y LA PROHIBICIÓN DE ABUSO DE DERECHO. EL PELIGRO DE INAPLICACIÓN DEL PRINCIPIO DE PROPORCIONALIDAD. XIV. LA PONDERACIÓN DEL TEDH EN EL CASO PERINÇEK C. SUIZA. XV. CONCLUSIÓN. 


\title{
LA NEGACIÓN O JUSTIFICACIÓN DEL GENOCIDIO COMO DELITO EN EL DERECHO EUROPEO. UNA PROPUESTA A LA LUZ DE LA RECOMENDACIÓN N. ${ }^{\circ} 15$ DE LA ECRI
}

\author{
MARÍA ELÓSEGUI ITXASO ${ }^{1}$
}

\section{INTRODUCCIÓN}

El objetivo de esta aportación es profundizar en la postura mantenida por la ONU, La Unión Europea ${ }^{2}$, el Consejo de Europa y por la jurisprudencia del TEDH

${ }^{1}$ Catedrática de Filosofía del Derecho. Facultad de Derecho. Universidad de Zaragoza. Calle Pedro Cerbuna, n. ${ }^{\circ}$ 12, 50009 Zaragoza. E-mail: elosegui@unizar.es Publicaciones en http://www. intercultural.unizar.es

La autora es experta independiente de la ECRI, Comisión contra el racismo y la intolerancia del Consejo de Europa, para la legislatura de 2013-2017. Las opiniones vertidas en este artículo se hacen en función de su investigación académica y no como miembro de dicho organismo. Este trabajo se inserta dentro de las líneas de investigación del «Grupo de Estudios Penales», grupo de investigación consolidado, subvencionado por el Departamento de Ciencia, Tecnología y Universidad del Gobierno de Aragón, así como por el Fondo Social Europeo, y cuyo responsable es el profesor Dr. don Miguel Ángel Boldova Pasamar (Catedrático de Derecho penal de la Universidad de Zaragoza).

Esta investigación se ha desarrollado en parte gracias a una visita de estudios realizada en la Dirección General de los Derechos Humanos y Asuntos Jurídicos, bajo la supervisión del Dr. Alfonso de Salas, Director Jefe de la División de Cooperación intergubernamental en materia de Derechos Humanos del Consejo de Europa, Dirección 1, con la consulta de los fondos bibliográficos y bases de datos de la biblioteca del Tribunal Europeo de Derecho Humanos. Agradezco también a la directora de la misma, Nora Binder, la ayuda que me ha ofrecido, así como las sugerencias realizadas por los dos evaluadores anónimos y la de mi colega Carmen Alastuey Dobón, profesora Titular de Derecho Penal.

2 Decisión marco 2008/913/JAI, de 20 de noviembre de 2008, relativa a la lucha contra determinadas formas y manifestaciones de racismo y xenofobia mediante el derecho penal (DOUE L 328, de 6 de diciembre de 2008). 
en relación con el delito de negacionismo y/o justificación del genocidio, especialmente del holocausto de los judíos, llevado a cabo por los nazis durante la Segunda Guerra Mundial ${ }^{3}$, así como las recomendaciones de la ECRI (Comisión contra el racismo y la intolerancia del Consejo de Europa), especialmente la n. ${ }^{\circ} 7^{4}$ y la $n .{ }^{o} 15^{5}$, para hacer una propuesta de la penalización de la negación y/o justificación del genocidio con unas condiciones muy delimitadas, dentro de los tipos de discriminación racial.

La cuestión de si penalizar o no la negación y/o justificación del genocidio nazi es un asunto controvertido en el ámbito penal, el derecho constitucional, el derecho internacional y entre historiadores ${ }^{6}$. Por ello la bibliografía académica existente es muy abundante ${ }^{7}$. Dejando al margen muchas otras cuestiones, el objetivo que ahora nos proponemos en esta aportación es muy concreto.

${ }^{3}$ Aunque la jurisprudencia del TEDH también versa sobre otros intentos de reconstruir en la actualidad en Europa nuevas dictaduras de izquierdas, no es este ahora nuestro tema.

${ }^{4}$ ECRI, Recommandation de politique générale n. ${ }^{\circ} 7$ de l'ECRI sur la législation nationales pour lutter contre le racisme et la discrimination raciales, adoptée le 13 décembre 2002, Strasbourg, Secrétariat de l'ECRI, Direction générale des droits de l’homme_DG II, Conseil de l'Europe, 17 de febrero de 2003, párrafo 41 sobre el párrafo 18 de la Recomendación.

5 ECRI, General Policy Recommendation N. ${ }^{\circ}, 15$ on combating Hate Speech, de 8 de diciembre de 2015, aprobada en su sesión plenaria (ecri/plenary meetings/2015/ecri15-45add6). La recomendación consta tan solo de diez artículos, pero lleva anexa una memoria explicativa de 63 páginas.

${ }^{6}$ En general los historiadores han sido muy reacios a las restricciones de la libertad de expresión y a la penalización de la negación de hechos históricos por miedo a ver mermada su libertad de investigación. Si bien algunos como Antoon De Baets, Profesor de Historia en la Universidad de Groningen (Holanda), no dudan en investigar sobre la responsabilidad de los historiadores y la posibilidad de manipular los hechos históricos por los propios profesionales. Cfr., DE BAETs, Antoon. (2012). «Conceptualising Historical Crimes», Historein, n. ${ }^{\circ} 11$, pp. 60-70, así como Responsible History. (2009). New York, Oxford, Berghahn Books. Sobre el principio de no intervención judicial en materia de hechos históricos, cfr., Ferreres Comella, Victor. (2006). «Freedom of Expression in Political Context: Some Reflecions on the Case Law of the European Court of Human Rights», en SADURSKI (ed.), Political Rights under stress in 21Th Century Europe, p. 84 y ss. Citado por ALCACER GUIRAO, Rafael (2013).«Libertad de expresión, negación del Holocausto y defensa de la democracia. Incongruencias valorativas en la jurisprudencia del TEDH», Revista española de derecho constitucional, n. ${ }^{\circ}$ 97, p. 319, nota 29.

7 Monografías específicas y valiosas sobre el tema son: Hochmann Thomas y Hennebel, Ludovic (2011). Genocide Denials and the Law, Oxford, Oxford University Press, 327 pp. y en ámbito español Teruel Lozano, G. (2015). La lucha del Derecho contra el negacionismo: una peligrosa frontera, CEPC, 615 pp, basada en una extensa tesis doctoral, disponible también en internet en Digitum; Repositorio institucional de la Universidad de Murcia en el sitio: http://digitum.um.es. Esta investigación ha recibido el premio Nicolás Serrano otorgada por el CEPC a la mejor tesis de Derecho Constitucional en 2014. Ver también Revenga. Miguel (Dir.). (2015). Libertad de expresión y discursos del odio, Universidad de Alcalá, Servicio de Publicaciones, resultado de una jornada organizada en la Fundación Manuel Giménez Abad, en la que tuve el gusto de participar. Igualmente HARE, Ivan y Weinstein, James (2009). Extreme Speech and Democracy, Oxford, Oxford University Press. 
Se trata de analizar la visión que la UE, el Consejo de Europa, el Tribunal Europeo de Derechos Humanos y la ECRI mantienen sobre la penalización de la negación y/o justificación de los genocidios. Asistimos a una creciente legislación vinculante para los 28 países miembros de la de la UE y los 47 del Consejo de Europa sobre esta cuestión. Entre las novedades más recientes se encuentran una nueva Recomendación de la ECRI, la n. ${ }^{\circ} 15$, on Combating Hate Speech, de 8 de diciembre de $2015^{8}$, para combatir el discurso del odio, que aunque no sea norma vinculante, es indicativa de hacia dónde van las últimas tendencias jurídicas europeas en este tema. En ella se dedica el artículo 10 al negacionismo?.

También es destacable la sentencia del TEDH en el caso Perinçek c. Suiza., de 15 de octubre de 2015. Así, como en ámbito español, la reforma del Código Penal de 2015, Ley Orgánica $1 / 2015$, de 30 de marzo $^{10}$, vuelve a introducir la

${ }^{8}$ ECRI, General Policy Recommendation n. ${ }^{\circ}, 15$ on combating Hate Speech, aprobada en su sesión plenaria (ecri/plenary meetings/2015/ecri15-45add6). La recomendación consta tan solo de diez artículos, pero lleva anexa una memoria explicativa de 63 páginas.

9 ECRI, General Policy Recommendation n. ${ }^{\circ}, 15$, Artículo 10: «Take appropiate and effective action against the use, in a public context, of hate speech which is intended or can reasonably be expected to incite acts of violence, intimidation, hostility or discrimination against those targeted by it through the use of the criminal law provided that no other, less restrictive, measure would be effective and the right to freedom of expression and opinion is respected, and accordingly:

a) ensure that the offences are clearly defined and take due account of the need for a criminal sanction to be applied:

b) ensure that the scope of these offences is defined in a manner that permits their application to keep pace with technological developments;

c) ensure that prosecutions for these offences are brought on a non-discriminatory basis and are not used in order to suppress criticism of oficial policies, political opposition or religious beliefs;

d) ensure the effective participation of those targeted by hate speech in the relevant proceedings;

e) provide penalties for these offences that take account both of the serious consequences of hate speech and the need for a proportionate response;

f) Monitor the effectiveness of the investigation of complaints and the prosecution of offenders with a view to enhancing both of these;

g) ensure effective co-operation/coordination between police and prosecution authorities;

h) provide appropiate training for and facilitate exchange of good practices by law enforcement officers, prosecutors and judges who deal with cases involving hate speech; and.

i) i. Cooperate with other States in tackling the transfrontier dissemination of that speech, wthether in a physical or electronic format».

${ }^{10}$ Ley Orgánica 1/2015, de 30 de marzo, por la que se modifica la Ley Orgánica 10/1995, de 23 de noviembre, del Código Penal, BOE, núm., 77 de 31 de marzo de 2015. Vigencia desde el 1 de julio de 2015 . 


\section{negación o justificación de la negación del genocidio como delito ${ }^{11}$, desligándo-} se en parte de la sentencia del TC español 235/2007, que fue motivo de nume-

11 Artículo 510 del Código Penal de 2015:

1. Serán castigados con una pena de prisión de uno a cuatro años y multa de seis a doce meses:

a) quienes públicamente fomenten, promuevan o inciten directa o indirectamente al odio, hostilidad, discriminación o violencia contra un grupo, una parte del mismo o contra una persona determinada por razón de su pertenencia a aquél, por motivos racistas, antisemitas u otros referentes a la ideología, religión o creencias, situación familiar, la pertenencia de sus miembros a una etnia, raza o nación, su origen nacional, su sexo, orientación o identidad sexual, por razones de género, enfermedad o discapacidad.

b) Quienes produzcan, elaboren, posean con la finalidad de distribuir, faciliten a terceras personas el acceso, distribuyan, difundan o vendan escritos o cualquier otra clase de material o soportes que por su contenido sean idóneos para fomentar, promover o incitar directa o indirectamente al odio, hostilidad, discriminación o violencia contra un grupo, una parte del mismo, o contra una persona determinada por razón de su pertenencia a aquel, por motivos racistas, antisemitas u otros referentes a la ideología, religión o creencias, situación familiar, la pertenencia de sus miembros a una etnia, raza o nación, su origen nacional, su sexo, orientación o identidad sexual, por razones de género, enfermedad o discapacidad.

c) Quienes públicamente nieguen, trivialicen gravemente o e enaltezcan los delitos de genocidio, de lesa humanidad o contra las personas y bienes protegidos en caso de conflicto armado, o enaltezcan a sus autores, cuando se hubieran cometido contra un grupo o una parte del mismo, o contra una persona determinada por razón de su pertenencia al mismo, por motivos racistas, antisemitas u otros referentes a la ideología, religión o creencias, situación familiar o a la pertenencia de sus miembros a una etnia, raza o nación, su origen nacional, su sexo, orientación sexual o identidad sexual, por razones de género, enfermedad o discapacidad, cuando de este modo se promueva o favorezca un clima de violencia, hostilidad, odio o discriminación contra los mismos.

2. Serán castigados con la pena de prisión de seis meses a dos años y multa de seis a doce meses:

a) Quienes lesionen la dignidad de la persona mediante acciones que entrañen humillación, menosprecio o descrédito de alguno de los grupos a que se refiere el apartado anterior, o de una parte de los mismos, o de cualquier persona determinada por razón de su pertenencia a ellos por motivos racistas, antisemitas u otros referentes a la ideología, religión o creencias, situación familiar o a la pertenencia de sus miembros a una etnia, raza o nación, su origen nacional, su sexo, orientación sexual o identidad sexual, por razones de género, enfermedad o discapacidad, o produzcan, elaboren, posean con la finalidad de distribuir, faciliten a terceras personas el acceso, distribuyan, difundan o vendan escritos o cualquier otra clase de material o soportes que por su contenido sean idóneos para lesionar la dignidad de las personas por representar una grave humillación, menosprecio o descrédito de alguno de los grupos mencionados, de una parte de ellos, o de cualquier persona determinada por razón de su pertenencia a los mismos.

b) Quienes enaltezcan o justifiquen por cualquier medio de expresión pública o de difusión los delitos que hubieran sido cometidos contra un grupo, una parte del mismo, o contra una persona determinada por razón de su pertenencia a aquél por motivos racistas, antisemitas u otros referentes a la ideología, religión o creencias, situación familiar o a la pertenencia 
rosos comentarios entre los juristas españoles ${ }^{12}$, suscitada por la consulta de inconstitucionalidad por la sala penal n. 3 de Barcelona en el asunto Varela Geiss $^{13}$ y que ha sido utilizada por el propio TEDH en la sentencia del TEDH (Gran Sala) de 15 de octubre de 2015, asunto Perinçek c. Suiza.

El ángulo desde el que se analiza en este artículo el tratamiento jurídico de las expresiones que niegan y/o justifican el Holocausto se inserta en la perspectiva del discurso del odio contemporáneo, visto en el contexto de la Europa, de una Europa de los 47 países firmantes del Convenio Europeo de Derechos Humanos, con Estados de derecho socialdemócratas y con una creciente interculturalidad. Una Europa que en la actualidad debe hacer frente a la diversidad de sus minorías nacionales y de un modelo de integración intercultural de su inmigración pasada y reciente, con profundas cicatrices sin restañar derivadas de la II Guerra Mundial

de sus miembros a una etnia, raza o nación, su origen nacional, su sexo, orientación sexual o identidad sexual, por razones de género, enfermedad o discapacidad, o a quienes hayan participado en su ejecución.

Los hechos serán castigados con una pena de uno a cuatro años de prisión y multa de seis a doce meses cuando de ese modo se promueva o favorezca un clima de violencia, hostilidad, odio o discriminación contra los mencionados grupos.

3. Las penas previstas en los apartados anteriores se impondrán en su mitad superior cuando los hechos se hubieran llevado a cabo a través de un medio de comunicación social, por medio de internet o mediante el uso de tecnologías de la información, de modo que, aquel se hiciera accesible a un elevado número de personas.

4. Cuando los hechos, a la vista de sus circunstancias, resulten idóneos para alterar la paz pública o crear un grave sentimiento de inseguridad o temor entre los integrantes del grupo, se impondrá la pena en su mitad superior, que podrá elevarse hasta la superior en grado.

12 Recogidas muchas de ellas por Rafael ALCÁCER GUIRAO en «Libertad de expresión, negación del holocausto y defensa ...», o.c., p. 313, nota 12. Así como Alastuey, C. (2014). «La reforma de los delitos de provocación al odio y justificación del genocidio en el Proyecto de Ley de 2013: consideraciones críticas «, Diario La Ley, Año XXXV, Número 8245, jueves, 6 de febrero de 2014, pp. 1-12, quien cita una extensa bibliografía que refleja la discusión doctrinal entre los penalistas españoles (p. 10).

13 la STC 235/2007, de 7 de noviembre, por la que se declara la inconstitucionalidad del delito de negación del genocidio. La SJP núm. 3 de Barcelona de 16 de noviembre de 1998 condenó al titular de la librería Europa en la que se vendían materiales vinculados al negacionismo del holocausto nacionalsocialista por los delitos del art. 510.1 y 607.2. del Código Penal español de 1995, ahora recogido en parte en el art. 510 del actual CP. Como resume Alastuey, C. o.c., pp. 10-11, nota 4: «Posteriormente, la AP Barcelona, en su sentencia de 5 de marzo de 2008, resolvió el recurso de apelación, absolviendo al condenado del delito de provocación a la discriminación, si bien mantiene la condena por el delito del art. 607.2. Posteriormente se inició otro procedimiento contra la misma persona, y el Juzgado de lo Penal núm. 11 de Barcelona vuelve a condenarle por los mismos delitos, pero la AP Barcelona, en sentencia de 26 de abril de 2010, le absuelve del delito del art. 510.1 y confirma también aquí la condena por el delito del art. 607.2». 
y de la reciente creación de nuevos Estados después de la desmembración de la República Socialista Soviética desde $1989^{14}$. Esta situación histórica condiciona y determina la visión europea del lugar que debe ocupar el derecho de libertad de expresión junto a otros derechos fundamentales. Todo ello justifica un tratamiento jurídico que difiere del realizado en el derecho estadounidense ${ }^{15}$.

Desde la atalaya del Consejo de Europa y con una perspectiva de una Europa amplía, la preocupación de la justificación del Holocausto, no se limita al reconocimiento de un tema histórico y de respeto a la memoria de sus víctimas o de sus descendientes, sino algo que va mucho más allá, estando relacionado con el presente. Inquieta el resurgir contemporáneo de ataques reales a la población judía en Europa, por ejemplo durante los ataques terroristas de París, y a otros muchos grupos étnicos, por razón de su pertenencia racial o religiosa ${ }^{16}$. En la actualidad más de 8,000 judíos se han ido trasladando a Israel después de la matanza de tres escolares en un colegio judío en Toulouse y hay 10.000 en lista de espera a raíz de la matanza en el supermercado kosher en París el día 9 de enero de 2015. En dicho país, los delitos racistas antisemitas e islamofóbico van en aumento y suelen ir precedido de discursos racistas que justifican el pasado del genocidio e incitan a cometer actos racistas contra grupos raciales, aunque en este caso no sea posible una absoluta exterminación de estos grupos ${ }^{17}$. Entre otros muchos problemas a la hora de establecer tipos penales que castiguen los discursos racistas la doctrina penal exige unas garantías penales y una definición precisa de los delitos, así como

14 Elósegui, M. (2013). El concepto jurisprudencial de Acomodamiento razonable. El Tribunal Supremo de Canadá y el Tribunal Europeo de Derechos Humanos ante la gestión de la Diversidad cultural y religiosa en el espacio público, Cizur Menor, Thomson Reuters-Aranzadi, 459 p.

15 Aunque quepa establecer alguna semejanza, en lo esencial las diferencias son abismales. Véase un acertado tratamiento en AlCACER Guirao, Rafael (2013).»Víctimas y disidentes. El «discurso del odio» en EEUU y Europa», Revista Española de Derecho Constitucional, n. ${ }^{\circ}$ 97, pp. 308-441.

16 Rollnert Liern, G. (2008). «Revisionismo histórico y racismo en la jurisprudencia constitucional: los límites de la libertad de expresión (A propósito de la STC 235/2007)», en Revista de Derecho político, núm. 73, pp. 103 y ss. En la p. 128, considera que en este segundo supuesto la justificación del genocidio persigue «crear un ambiente propicio» que facilite la ulterior realización del delito del art. 510.1; es decir, «vendría a ser una suerte de conducta preparatoria de la provocación a la discriminación, al odio o a la violencia».

17 Reynier, Dominique. (2014). «L'antisémitisme dans l’opinion publique française. Nouveaux éclairages», Fondapol, noviembre. Disponible en el sitio web: www. fondapol. org. Según este estudio tres segmentos de la sociedad francesa son particularmente receptivos a los estereotipos antisemitas: los simpatizantes del Frente Nacional y los votantes de Marine Le Pen, una proporción de población musulmana y los simpatizantes del Frente de Izquierdas y los que votan a Jean-Luc Mélenchon. Véase ECRI V Report on France, CRI(2015)41-1, adoptado el 30 de noviembre de 2015 [CRI (2015)41-1.], en su 68 reunión plenaria. Ver párrafo 24 sobre el discurso de odio antisemita y el punto 26 sobre el discurso del odio islamofóbico. Disponible en http: www.coe. int/ecri. 
los elementos del tipo, el bien jurídico protegido, el titular del derecho, la definición del tipo de peligrosidad, preguntándose hasta dónde sería legítimo y deseable adelantar la barrera punitiva. En suma, si crear un ambiente propicio o un clima de violencia u hostilidad debería ser ya penado ${ }^{18}$.

Teniendo en cuenta la importancia de respetar exquisitamente las pertinentes técnicas jurídicas de ponderación de derechos en juego, el principio de proporcionalidad, la prueba y las garantías procesales, el análisis del contexto geográfico, las circunstancias concretas del caso, el peligro concreto o inminente, potencial o abstracto, el peligro presunto y el simbólico ${ }^{19}$, el análisis de la incitación directa o indirecta ${ }^{20}$, la intencionalidad racista, el dolo especial, las repercusiones de esos discursos en la incitación a delinquir, no se puede perder de vista la realidad social europea contemporánea. Un buen punto de referencia de la misma son los informes que la ECRI elabora continuamente sobre cada uno de los países pertenecientes al Consejo de Europa ${ }^{21}$. Concretamente, uno de los ámbitos en los que el revisionismo hace mella es en las jóvenes generaciones a

${ }^{18}$ No vamos a reflejar la imprescindible discusión aplicada a la reforma penal del art. 510 en el Código penal español en 2015, sino que veremos las conclusiones del marco penal aconsejable que se derivan del Derecho europeo. Efectivamente la reforma española ha adelantado la barrera de punición a los delitos de clima y esto no es algo exigible por el derecho europeo. Para una crítica de la reforma ya realizada en 2015, Teruel Lozano, G., «La libertad de expresión frente a los delitos de negacionismo y de provocación al odio y a la violencia: sombras sin luces en la reforma del Código Penal», Indret, 2015, pp. 2-51. También crítica con el proyecto anterior de reforma, véase Carmen Alastuey Doвón, C. (2013). «La reforma de los delitos de provocación al odio y justificación del genocidio en el Proyecto de Ley de 2013: consideraciones críticas», La Ley, n. ${ }^{\circ} 8245$, jueves, 6 de febrero de 2014, pp. 1-18. En esta contribución se analiza, en primer lugar, la interpretación doctrinal y jurisprudencial de las figuras delictivas de provocación al odio (art. 510.1) y justificación del genocidio (art. 607.2) llevada a cabo desde su entrada en vigor, con el fin de poner de manifiesto las críticas formuladas respecto de esta regulación, así como las propuestas de reforma. En segundo lugar, se estudia la modificación de estos delitos que aborda el Proyecto de Ley de reforma del Código Penal, de septiembre de 2013, exponiendo los considerables defectos en los que incurre la regulación proyectada.

19 Alcacer Guirao, R. (2013). «Libertad de expresión, negación del Holocausto y defensa de la democracia. Incongruencias valorativas en la jurisprudencia del TEDH», o.c., pp. 333-338.

20 Alcácer Guirao, R. (2012). «Discurso del odio y discurso político. En defensa de la libertad de los intolerantes», en Revista Electrónica de Ciencia Penal y Criminología (RECPC), 14 de febrero de 2012. Ddisponible en http://criminet.ugr.es/recp, 14-02, 32 p. Aquí pp. 17-18, «Requisito mínimo, en este sentido, para su acomodación constitucional sería una interpretación restrictiva de esa modalidad delictiva según la que la incitación al odio se realizara en tales condiciones y con tal intensidad que, aunque no existiera una incitación directa a la violencia, fuera previsible la realización inminente de actos lesivos para miembros del grupo social concernido».

${ }^{21}$ Consejo de Europa (COE), ECRI. Ver especialmente los últimos informes sobre Francia, Bélgica, Holanda y Austria correspondientes al V ciclo. Disponibles en http: www.coe.int/ecri. El 5. ${ }^{\circ}$ informe sobre Francia es de 30 de noviembre de 2015 (CRI (2015)41-1. 
través de los hinchas del futbol, de los conciertos racistas, la llamada música del odio, o de partidos políticos extremistas de derechas. En ellos se describe un aumento sustancial de discursos revisionistas y de discursos de odio, que incitan a ataques verbales y físicos sobre los grupos que previamente han sido objeto de esos discursos, minorías étnicas, inmigrantes y refugiados ${ }^{22}$.

Los grupos violentos en España, pero igualmente en el resto de países europeos, provienen de dos ideologías antagónicas, la extrema derecha, neonazis, pero también, aunque quizá sea menos conocido, de grupos antifascistas o anarquistas de extrema izquierda. En ambos casos, los distintos grupos además de agredir a grupos vulnerables, se enfrentan también entre si de modo violento, movidos por el odio y por estereotipos ${ }^{23}$. En noviembre de 2014 tuvo lugar el asesinato de Francisco Javier Romero de 43 años, ultra del equipo gallego más radical «Riazor Blues» en un enfrentamiento de bandas rivales (una de izquierdas y la otra de derechas) que acudían a un partido de futbol del atlético de Madrid. El proceso judicial se ha cerrado, casi sin imputados.

Los grupos de extrema derecha tienen como finalidad un objetivo racista, de exterminio de personas de color, inmigrantes y homosexuales. En España se han registrado numerosos homicidios por estas causas. El perfil y las características de estos grupos violentos, sus modos de actuación coincide con el de grupos de otros países europeos, como Italia, UK, Bélgica, Austria, Polonia, los países de la ex Yugolasvia, Hungría y Rusia. En España se dio paso a la ilegalización de dos asociaciones, la de HammerSkin y Blood and Honour a través de sentencias judiciales por vía penal ${ }^{24}$. La aceptación de este fenómeno por parte de las autoridades fue costoso, ya que dentro de los propios cuerpos policiales ha habido

${ }^{22}$ En relación con España es significativa la memoria de conductas de odio racista cometidas en dicho país. Véase, Movimiento contra la Intolerancia. (2015). Informe Raxen. Racismo, Xenofobia, Antisemitismo, Islamofobia, Neofacismo y otras manifestaciones relacionadas con la intolerancia a través de los hechos. Especial 2015 (1). El avance de la Xenofobia en Europa, Madrid, edita Movimiento contra la intolerancia.

${ }^{23}$ Cfr., el V Informe de la ECRI sobre Francia, de 2016, párrafo 48, en el que se menciona a Clément Méric, un antifascista que murió en junio de 2013 por heridas provocadas por un skinhead.

${ }^{24}$ STS (Sala de lo Penal, sección 1) núm. 2014/2015, de 5 de febrero rechaza el recurso de apelación (núm. 1521/2014) contra la sentencia del Tribunal Provincial de Madrid, Sección 3.a , de 24 de junio de 2014, que ha condenado a José María, como autor penalmente responsable de un delito de asociación ilegal por pertenecer a Blood and Honour España, un grupo de ideología neonazi, que promueve el odio basado en la raza, a través de la edición y distribución de revistas y eventos públicos (art. 515. 5. ${ }^{\circ}$ en relación con el art. 517. 2. del Código Penal): «También se intervinieron discos, destinados a su venta y algunos coincidentes con los ocupados en el local con canciones cuyas letras promueven la xenofobia tales como «Mis vecinos son apestosos turcos y en el parque de enfrente vaguea un negrata», "te partiré la boca hasta que cruja», «Estamos hartos de una tiranía judía y si el país se hunde es por culpa de esta mezcla de razas», 
connivencia con estos grupos por parte de miembros de los mismos que comparten también el racismo contra los inmigrantes o los extranjeros. En la mayoría de casos, las víctimas han estado indefensas y han sido maltratadas a su vez si emprendían una denuncia.

El fútbol se convierte en una sede de violencia racista. El fenómeno no es algo marginal, sino que sus miembros son de extracto social medio y alto, algunos universitarios, y la edad se extiende desde jóvenes de 15 años hasta personas ya mayores de 40 años. Son grupos en los que se posee un sentido de pertenencia e identidad en una sociedad cada vez más individualista ${ }^{25}$.

El fenómeno es preocupante ya que muchas de estas asociaciones están apoyadas y protegidas por los clubes de futbol y por los partidos políticos de extrema derecha. De hecho, sus socios tienden a militar y a apoyar a dichos partidos.

Nos encontramos con un avance en el derecho europeo en la dirección de penalizar la negación y/o justificación de los genocidios cuando poseen una intención racista. En esta línea situaríamos las recientes reformas del Código Penal español, que ha vuelto a introducir la negación del genocidio y no sólo su justificación en el Código Penal español, rompiendo con la doctrina de la sentencia del TC 235/2007, que había establecido esa barrera, si bien esta última ha sido comentada y criticada por muchos penalistas ${ }^{26}$ y constitucionalistas españoles $^{27}$.

En el ámbito del Consejo de Europa, la tendencia creciente es animar a los Estados parte a que introduzcan en sus códigos penales una mayor dureza y restricciones de la libertad de expresión cuando está relacionada con el discurso racista o discurso del odio, con intención racista, incluyendo los delitos de negacionismo como parte del discurso del odio. En esta línea además el Consejo de Europa ha elaborado el primer tratado internacional jurídicamente vinculante sobre cibercriminalidad, relativo a la incriminación de actos de naturaleza racista y xenófobos cometidos a través de los sistemas informáticos, Convenio n. ${ }^{\circ} 185$,

«Primero se mete el gas en la cámara, se sella, se colocan unas alcachofas y un desagüe, y acabado está el holocausto»».

${ }^{25}$ Cfr., SuÁrez Pombo, José Luis y Docal, David (2014). Odio en las calles. Vivencia urbana, Almería, editorial Círculo Rojo, 370 pp. García García, Ricardo y Docal, David (2012). Grupos de odio y Violencias Sociales, Madrid, editorial Rasche, 1. ${ }^{a}$ edición, 193 pp.

26 Véase bibliografía recogida por Carmen Alastuey Lobón, o.c. pp. 9-10.

27 Recogidas por AlCÁCER GUIRAO, Rafael (2013), en «libertad de expresión, negación del holocausto y defensa ...», o.c., p. 313, nota 12. También Revenga SÁnchez, Miguel (2015). «Los discursos del odio y la democracia adjetivada: tolerante, intransigente, ¿militante?», en Miguel Revenga (Dir.), Libertad de expresión y discursos del odio, Universidad de Alcalá, Servicio de Publicaciones, pp. 15-32. 
del Consejo de Europa, adoptado por el Consejo de Ministros el 8 de noviembre de 2001.

Entre la última jurisprudencia del TEDH destaca el fallo en el caso Perinçek c. Suiza, emitido por la Gran Sala. Aunque recoge los criterios sentados por el anteriormente por el TEDH, no deja de ser una sentencia polémica, ya que el voto mayoritario, avalado por 10 jueces de la Corte, ha fallado que Suiza ha injerido en la libertad de expresión del demandante, artículo 10 del CEDH, porque las medidas de injerencia no han sido proporcionales en una sociedad democrática como la Suiza al interpretar los tribunales de ese país que la negación del genocidio armenio se puede subsumir en el tipo penal previsto en el art. 261 bis, 1, párrafo 4, del código penal suizo que condena la negación de genocidio. Pero, la Sentencia pone de manifiesto la división dentro del propio Tribunal, ya que el voto minoritario elaborado por siete magistrados, muestra la dificultad práctica a la hora de calificar los hechos, la intención racista y las medidas restrictivas en el caso concreto, juzgando todo lo contrario a lo establecido por el voto mayoritario. Si a ello añadimos, que una de las jueces realiza un voto concurrente porque está de acuerdo con que ha habido una violación formal del derecho de libertad de expresión, pero no una violación material, y si restamos su opinión del voto mayoritario, tendríamos que en realidad la mayoría ha ganado sólo por un voto de diferencia.

En relación con los límites a la libertad de expresión en el derecho europeo, por un lado, se trata de establecer qué modelo antropológico jurídico-político subyace a las democracias occidentales contemporáneas. Está claro que en Estados Unidos prevalece un modelo basado en el liberalismo clásico, pero la mayoría de los países europeos responden a un modelo social de Estado, que reclama una intervención del mismo para la protección de la igual dignidad de todos los ciudadanos y para evitar la discriminación racial o religiosa ${ }^{28}$. El derecho a la libertad de expresión no sólo no es un derecho absoluto, sino que es un derecho que colinda con otros derechos como el respeto a la dignidad, honor e igualdad de todas las personas y su seguridad existencial ${ }^{29}$. Ese es en buena medida el

${ }^{28}$ Sobre la discusión relativa a la protección penal de la dignidad, tomando partido a favor del reconocimiento de la dignidad humana como bien jurídico, véase Alonso Álamo, M., (2013). «Derecho penal y dignidad humana. De la no intervención contraria a la dignidad a los delitos contra la dignidad», en Libro Homenaje al profesor Luis Rodríguez Ramos, Tirant lo Blanch, Valencia, pp. 298 y ss. Laurenzo Copello (1996), «La discriminación en el Código Penal de 1995», EPC, XIX, pp. 219 y 236 y ss.

29 Landa Gorostiza, J. M., (1999). La intervención penal frente a la xenofobia. Problemática general con especial referencia al "delito de provocación» del artículo 510 del Código Penal, Zarautz, Universidad del País Vasco, pp. 238 a 240, pp. 346 y ss. Las condiciones de seguridad existencial 
espíritu del Convenio Europeo de Derechos Humanos, en su artículo 10 sobre el derecho de libertad de expresión y sus límites ${ }^{30}$. El hecho de que naciera en el contexto de postguerra no desacredita su validez actual porque hoy en la Europa contemporánea seguimos teniendo que afrontar violaciones de derechos humanos similares, y tampoco nos hemos librado de nuevos genocidios o crímenes de guerra como los ocurridos en la antigua Yugoslavia en 1993.

En ámbito académico español es común entre constitucionalistas priorizar el derecho a la libertad de expresión e intentar que las injerencias en el mismo sean mínimas ${ }^{31}$. Del mismo modo entre penalistas ha sido mayoritaria la crítica a la reforma del Código Penal español y la nueva articulación de los delitos de justificación del genocidio y de delitos de odio ${ }^{32}$, si bien apreciamos una sensibilidad

aludirían «al conjunto mínimo de condiciones necesarias para que todos los miembros de un colectivo puedan desarrollar sus actividades como sujetos de pleno derecho en la sociedad» (p. 351). Algunos asignan a la libertad de expresión una posición preferente, interpretación y opinión que no comparto. AlCacer Guirao, Rafael (2013). «Libertad de expresión, negación del holocausto», o.c., p. 310, en el que remite en la nota 4 a MAgdaleno, Alegría (2006). Los límites de la libertad de expresión en el Estado Social y democrático de Derecho, pp. 283 y ss: Villaverde Menéndez, «La libertad de expresión» (2009). en CASAs/RodríGuez-PIÑERo, Comentarios a la Constitución, pp, 472 y ss, sobre la doctrina del tribunal constitucional español.

${ }^{30}$ Convenio Europeo de Derechos Humanos: Art. 10. 1: «Toda persona tiene derecho a la libertad de expresión. Este derecho comprende la libertad de opinión y la libertad de recibir o comunicar informaciones o ideas, sin que pueda haber injerencia de autoridades públicas y sin consideración de fronteras. El presente artículo no impide que los Estados sometan a las empresas de radiodifusión, de cinematografía o de televisión a un régimen de autorización previa». Art. 10.2: «El ejercicio de estas libertades, que entrañan deberes y responsabilidades, podrá ser sometido a ciertas formalidades, condiciones, restricciones o sanciones previstas por la ley, que constituyan medidas necesarias, en una sociedad democrática, para la seguridad nacional, la integridad territorial o la seguridad pública, la defensa del orden y la prevención del delito, la protección de la salud o de la moral, la protección de la reputación o de los derechos ajenos, para impedir la divulgación de informaciones confidenciales o para garantizar la autoridad y la imparcialidad del poder judicial».

31 Bustos Gisbert, Rafael (2015). «Libertad de expresión y discurso negacionista», en Miguel Revenga (dir.), Libertad de expresión y discursos de odio, o.c., pp. 123-147. Cuerda ARnau, M. L. (2001). «El denominado delito de apología del genocidio. Consideraciones constitucionales», en Quintero Olivares y Morales Prats (Coord.), El nuevo Derecho penal español. Estudios penales en memoria del profesor José Manuel Valle Muñiz, Aranzadi, Pamplona, pp. 1125 y ss.

32 Alcácer Guirao, R., (2012). «Discurso del odio y discurso político. En defensa de la libertad de los intolerantes», RECPC, o.c., FeIjoo SÁNCHEZ, B. J., (1998). «Reflexiones sobre los delitos de genocidio (artículo 607 del Código Penal)», La Ley, núm. 6, pp. 2267 y ss. Landa Gorostiza, J. M. (1999). La intervención penal frente a la xenofobia. Problemática general con especial referencia al «delito de provocación» del artículo 510 del Código Penal, Universidad del País Vasco, Zarautz. Del mismo autor, Landa Gorostiza, J. M., (1999). «La llamada «mentira de Auschwitz» (art. 607.2. ${ }^{\circ} \mathrm{CP}$ ) y el «delito de provocación» (art. $510 \mathrm{CP}$ ) a la luz del «caso Varela»: 
distinta entre filósofos del derecho y eclesiasticistas ${ }^{33}$. No es el objetivo de este artículo abordar los debates de la doctrina española en estos aspectos, sino trazar una panorámica vista desde el derecho del Consejo de Europa.

Esta situación compleja quizá sea la razón por la que mientras en ámbitos teóricos se es más propicio a la despenalización de determinadas conductas o a protegerlas desde el derecho constitucional, sin embargo los propios legisladores europeos vayan en la dirección contraria, aumentando los ámbitos de penalización del discurso del odio, a pesar de que el uso del derecho penal deba atenerse al principio de la última ratio o principio de intervención mínima. Por un lado, la definición de los conceptos constituye ya en sí un tema espinoso que da lugar a continuas disputas académicas ${ }^{34}$. Ante la imposibilidad de detenernos ahora en todos los puntos discutidos, nos vamos a ceñir sólo a la redacción expresa de la legislación vigente en la UE y en el Consejo de Europa, en la Recomendaciones n. ${ }^{0} 7$ y 15 de la ECRI a la hora de definir los términos que se reflejan en esa normativa y en la jurisprudencia del TEDH.

Admitiendo el peligro de que el legislador se extralimite al regular sobre esta materia, en este artículo tratamos de dar respuesta principalmente a una pregunta, ¿es conveniente la introducción en la normativa común de la UE y del Consejo de Europa y en los códigos penales europeos del delito de la negación y/o justificación del holocausto nazi, es decir de la exterminación de judíos realizado por el régimen nacionalsocialista de Hitler durante la II Guerra Mundial?

una oportunidad perdida para la «cuestión de inconstitucionalidad». (Comentario a la Sentencia del Juzgado de lo Penal núm. 3 de Barcelona de 16 de noviembre de 1998)», en Actualidad Penal, núm. 36, pp. 689 y ss (cit. 1999-2). LANDA Gorostiza, J. M., (2001). La política criminal contra la xenofobia y las tendencias expansionistas del Derecho penal, Granada, Comares. LANDA GorostizA, J. M., (2012). «Incitación al odio: evolución jurisprudencial (1995-2011) del art. 510 CP y propuesta de lege lata», Revista de Derecho penal y Criminología, n. ${ }^{\circ}$ 7, pp. 297 y ss.

33 Entre los primeros situaríamos a GASCón CuEnCA, Andrés (2015). «La nueva regulación del discurso del odio en el ordenamiento jurídico español: la modificación del artículo $510 \mathrm{CP}$ », Cuadernos electrónicos de Filosofía del Derecho, n. ${ }^{\circ} 32$, pp. 72-92 y PÉrez de LA Fuente, Óscar (2010). «Sobre el Holocausto: el imperativo de la memoria en el ámbito del Derecho y de la Historia», AFDUC, 14, pp. 91-119. Entre los eclesiasticistas, solo a modo de ejemplo, LóPEZ-Sidro, Ángel (2013). «Negacionismo y discurso del odio en España», en PÉrEZ-MADrID, Francisca y Gas Aixendri, Montserrat, La Gobernanza de la Diversidad Religiosa, Cizur Menor, Thomson Reuters-Aranzadi, pp. 75-99 y MARTínEZ-TorRón, Javier (1986). «El derecho de libertad religiosa en la jurisprudencia en torno al Convenio Europeo de Derechos Humanos», Anuario de Derecho Eclesiástico del Estado, II, pp. 403-496.

34 Cuerda Arnau, M. L. (2001). «El denominado delito de apología del genocidio. Consideraciones constitucionales», en Quintero Olivares y Morales Prats (Coord.), El nuevo Derecho penal español. Estudios penales en memoria del profesor José Manuel Valle Muñiz, Aranzadi, Pamplona, pp. 1125 y ss. 
¿Cuál es el contexto europeo? Caso de responder afirmativamente a la conveniencia de penalizar la negación y/o justificación del genocidio nazi, por lo menos en algunos países europeos, ¿conviene hacer extensivo el delito a otros genocidios?, ¿a otros crímenes contra la humanidad? ¿A crímenes de guerra? ¿Cuándo utilizamos el término «genocidio» desde el punto de vista de un marco legal a qué nos estamos refiriendo? Un atento escrutinio de la legislación da respuesta a varias de estas cuestiones y lleva a clarificar un marco común de consenso en el derecho internacional de Naciones Unidas, de la UE y del Consejo de Europa, incluida la jurisprudencia del TEDH, y especialmente si nos servimos de las Recomendaciones de la ECRI sobre el uso jurídico de esta expresión.

Tras examinar las relaciones y diferencias entre el derecho y su relación con la historia y la cuestión de si cabe hacer una distinción entre el negacionismo simple o neutral frente al negacionismo cualificado (II), se sostendrá las razones por las que propugnamos que el negacionismo revisionista no debería estar protegido por el Derecho a la libertad de expresión y de investigación (III). A continuación se examina la definición de genocidio en los instrumentos de Naciones Unidas y la diferencia con los crímenes contra la humanidad (IV), la normativa de la UE (V) y del Consejo de Europa, concretamente el Convenio sobre Cibercriminalidad relativo a la penalización de actos de naturaleza racista y xenófoba cometidos a través de sistemas informáticos y su protocolo adicional (VI). Se plantean algunos problemas de interpretación de la legislación del Consejo de Europa y de la UE; especialmente el que no se exija demostrar la intención racista en el Convenio sobre Cibercriminalidad del Consejo de Europa (VII). Como contraste se resalta el requisito de intención racista en la Recomendación n. ${ }^{\circ} 7$ de la ECRI (VIII), así como la definición de negacionismo como una forma de discurso del odio en la Recomendación n. ${ }^{\circ} 15$ de la ECRI, que sitúa las normativas para combatir los discursos racista en el contexto de la lucha contra la discriminación racial, y no en el contexto de delitos contra el derecho internacional, lo que juzgamos como un acierto (IX). Desde esa perspectiva aportada por la ECRI, se analiza el criterio sentado por el TEDH sobre considerar como no protegible por el derecho de libertad de expresión la negación y/o justificación de los hechos históricos claramente establecidos referidos al Holocausto, frente al legítimo debate de ideas (X). Se recoge la jurisprudencia del Tribunal Europeo de Derechos Humanos, en relación con la libertad de expresión y sus límites en los casos de negación de hechos históricos (XI), especialmente la inadmisibilidad de demandas de negacionistas a través de la aplicación del artículo 17 del Convenio sobre la prohibición de abuso de derecho, así como criticamos la inaplicación del principio de proporcionalidad. Sugerimos que cara a futuro el TEDH debería siempre proceder a un examen de ponderación, utilizando el principio 
de proporcionalidad (XII). Como un ejemplo real de los problemas que suscita la interpretación de normas de penalización de la negación del genocidio y de ponderación de los derechos en conflicto estudiamos los argumentos en la sentencia del TEDH Perinçek c. Suiza, en la que precisamente el voto mayoritario se ve puesto en cuestión por un número elevado de jueces con una opinión disidente, en la que interpretan de modo totalmente opuesto, tanto la compatibilidad de la norma del código penal suizo con el Convenio Europeo, como la existencia o ausencia de intención racista en el demandante, considerando adecuado el fallo de los tribunales internos suizos (XIII). Todo ello nos permite alcanzar las conclusiones, en la que se defenderá la necesidad de penalizar la negación y/ o justificación del Holocausto judío, siempre que se pruebe la intención racista y se siga un daño concreto a personas individuales y/ o grupos, siendo el bien jurídico protegido la igual dignidad de la persona y su integridad moral (o física) y haya un peligro claro y concreto de que ese daño se produzca (XIV), pudiendo imputarse un nexo causal de responsabilidad mediata o inmediata.

\section{EL DERECHO Y SU RELACIÓN CON LA HISTORIA: RELACIONES Y DIFERENCIAS. EL NEGACIONISMO SIMPLE O NEUTRAL FRENTE AL NEGACIONISMO CUALIFICADO}

Ciertamente es imprescindible distinguir entre la historia y el derecho, o la verdad histórica y la verdad jurídica, en los aspectos en que esto sea posible, pero muchas veces la frontera será difusa. En muchas ocasiones ambas ciencias se coadyuvan y se necesitan mutuamente, en otras se solapan, en otras cabe que entren en conflicto incluso con la condena civil o penal de algunos historiadores profesionales. Aunque esto en la actualidad no sea lo frecuente, no podemos obviar la realidad de ciertas injerencias injustas en la libertad de expresión o de cátedra, que se han producido, especialmente en Francia, al aplicar legislaciones cuya redacción es ambigua ${ }^{35}$.

A pesar de esos problemas reales, en relación con el objeto de nuestro tema se discute si existe una diferencia entre el negacionismo y la justificación del holocausto judío. En las normas europeas y en las legislaciones nacionales se ha identificado estos conceptos porque en casi todos los casos que llegan a los tri-

35 Para un análisis detallado de las leyes francesas, las leyes memoriales, la ley Gayssot, la ley Toubira, véase Fraser, David (2011). «Law’s Holocaust Denial. State, Memory, Legality», en Genocide Denials and the Law, o.c., pp. 27-48. También Troper, Michel. (2001). «Derecho y negacionismo: la Ley Gayssot y la Constitución», En Anuario de derechos humanos, n. ${ }^{\circ}$, pp. $957-984$. 
bunales quienes niegan lo hacen para justificar y en general se refieren tan sólo al Holocausto. Como voy a intentar razonar a continuación, en la práctica la distinción entre negación y justificación es artificial, si atendemos al uso que hacen del negacionismo los actuales revisionistas. Por tanto, en este punto no comparto la distinción realizada por el Tribunal Constitucional español en la sentencia de 2007, adhiriéndome a la tesis del Magistrado Pascual Sala en su voto particular ${ }^{36}$. Junto a ello admito que dado que las legislaciones nacionales ${ }^{37}$ y las normas internacionales deberían estar redactadas con mayor precisión y de hecho son ambiguas, cautelarmente para diferenciar entre la libertad de expresión e investigación de los historiadores ${ }^{38}$ se debería distinguir mejor en las normas penales cara a futuro, distinguiendo, como se ha denominado en la doctrina, entre el negacionismo simple o neutral frente al negacionismo cualificado, acogiendo alguna de las propuestas de Teruel Lozano, dejando claro que para que haya delito se requiere intención racista o dolo especial ${ }^{39}$. Como veremos más adelante la Recomendación n. ${ }^{\circ} 15$ de la ECRI y su memorándum interpretativo aconseja que los tipos penales estén redactado con claridad y precisión porque sin esto se incurre en falta de seguridad jurídica ${ }^{40}$. Entre las medidas para evitar penalizaciones abusivas en el punto 10 de la Recomendación n.$^{\circ} 15$ se tiene en cuenta el riesgo de que se exijan responsabilidades penales de un modo injustificado para suprimir la crítica de posturas oficiales, de la oposición política y de las creencias religiosas. Este uso sería incompatible con los requisitos que se establecen en esta recomendación. Además, se añade que sería apropiado reforzar este punto incluyendo en las leyes relevantes un estipulación explícita de que los tipos penales no son aplicables a este tipo de crítica, oposición o creencias $^{41}$.

${ }^{36}$ Cfr., Voto particular del Magistrado Jorge Rodríguez-Zapata Pérez, respecto de la sentencia del Pleno de 7 de noviembre de 2007, referente al delito de difusión de ideas que nieguen o justifiquen delitos de genocidio, STC 235/2007. Cuestión de inconstitucionalidad 5152-2000. Planteada por la Sección Tercera de la Audiencia Provincial de Barcelona respecto al artículo 607.2 del Código Penal.

37 Comparto las críticas a la mala redacción del artículo 607. 2 del Código Penal de 1995 y las actuales deficiencias en la redacción del actual Código tras su reforma. Véase Teruel LozAno, G. (2015). «La libertad de expresión frente a los delitos de negacionismo y de provocación al odio y a la violencia: sombras sin luces en la reforma del código penal», Indret, octubre, pp. 21-22.

38 Sobre el derecho de libertad de investigación y de cátedra, véase VIDal Prado, Carlos (2001). La libertad de Cátedra: un estudio comparado. Madrid, Centro de Estudios Constitucionales.

39 Teruel Lozano, G. (2015). La lucha del Derecho contra el negacionismo: una peligrosa frontera, Madrid, CEPC, pp. 433-436.

${ }^{40}$ ECRI, General Policy Recommendation N. ${ }^{\circ}, 15$ on combating Hate Speech, Explanatory Memorandum, Recommendation 10, n. ${ }^{\circ} 175$.

${ }^{41}$ Idem, n. ${ }^{\circ} 180$. 
Ello no impide que atendiendo a la jurisprudencia, la mayoría de los casos tratados por ella coincidan con la tesis de Tajadura Tejada para quien la evidencia empírica demuestra que «todos los que niegan el genocidio son racistas antisemitas porque sus afirmaciones sólo se comprenden en el marco del discurso del odio ${ }^{42}$. De hecho en el contexto del derecho europeo se equipara el negacionismo del holocausto a la justificación y se ha dado amparo a los pocos verdaderos historiadores que han recurrido al TEDH en casos en que eran verdaderos profesionales investigadores. Es famoso el caso Lehideux e Isorni c. Francia, de 23 de septiembre de 1998. Los demandantes, historiadores, habían sido condenados por los tribunales franceses por realizar una interpretación sobre el papel jugado por el Mariscal Pétain y el Régimen jurídico de Vichy durante la segunda Guerra Mundial durante la ocupación de Francia por los nazis. Analizan el papel polémico de la política de Pétain calificándola de «doble juego». En ningún momento se mostraban favorables al nazismo. El TEDH consideró que Francia había aplicado una condena penal desproporcionada. Además estos hechos históricos están en la actualidad sometidos al debate de los historiadores y no hay una verdad histórica probada. En el citado país hay de hecho un enorme malestar entre historiadores por los intentos de introducir prohibiciones penales de negación de otros hechos históricos como el del genocidio armenio. La Asamblea francesa votó una ley que castigaba la negación del genocidio armenio el 12 de octubre de 2006 (previamente en 2001 se había aprobado una ley reconociendo la matanza de armenios como un genocidio), con multas de 45.000 euros y pena de hasta un año de prisión, pero fue rechazada por el Senado en mayo de 2006. En 2011 se anunció otro proyecto de Ley, pero el Consejo Constitucional francés declaró en enero de 2012 que dicha ley violaba la libertad de expresión.

En el mencionado Estado se han vivido hechos lamentables como la acción civil contra el historiador francés Bernard Lewis, quien ha sido condenado por opinar que la masacre de los armenios no reúne los requisitos para ser considerada como un genocidio ${ }^{43}$. Así como otra denuncia contra Olivier Pétré-Grenouilleau, acción que fue finalmente abandonada, por su obra sobre la trata de negros en Francia ${ }^{44}$. Si bien en otros casos famosos, como el de Le Pen, la conde-

42 Tajadura Tejada, Javier (2008). «Libertad de expresión y negación del genocidio: comentario crítico a la STC de 7 de noviembre de 2007, Revista Vasca de Administración Pública, n. ${ }^{\circ} 80$, pp. 233 -255. Aquí p. 254. Disponible texto completo en versión electrónica en el buscador Dialnet.

43 T. G. I, Paris, 21 de junio de 1995. CDCA et Liera c. Bernard Lewis.

44 «Laissons les historiens faire leur métier $i »$, en Entretien avec Françoise CHANDERNAGOR, L Histoire, n. ${ }^{\circ}$ 306, février 2006. Disponible en http://histoire presse.fr.: También $c f r$., »Retrait de la plainte contre un historien de l'esclavage», Le Monde, 4 février 2006. 
na por sus expresiones generales negativas contra los inmigrantes no europeos y en particular contra los musulmanes en Francia, estaba totalmente fundamentada y el TEDH en su decisión de inaceptabilidad de 2010 así lo consideró ${ }^{45}$. También en el caso de Seurot, un profesor de historia de secundaria, que criticaba en clase a inmigrantes magrebíes franceses ${ }^{46}$, conducta que no estaba amparada por la libertad de cátedra.

Precisamente por estas injerencias posibles de los Estados en la libertad de investigación, desde el punto de vista jurídico sería deseable una mayor precisión en el lenguaje empleado por los legisladores para evitar la injusta persecución de legítimos historiadores. Bien es cierto que la entrada en vigor de cada una de estas normas se ha realizado tras largos debates parlamentarios nacionales y en diferentes instancias en el caso de la legislación internacional. Llegar a acuerdos no ha resultado fácil. En los temas históricos la emoción juega un papel importante tanto en los legisladores, como en los jueces, como en los ciudadanos.

Como contraste con los verdaderos historiadores, por parte de los negacionistas, se da también una contradicción en el uso de la razón. Se dejan llevar por sus emociones y prejuicios previos y sus sentimientos, aunque usen a su vez argumentos disfrazados de aparente racionalidad. La razón y el conocimiento deberían utilizarse para no negar hechos objetivos de la historia.

Al margen de la función propia de los historiadores sobre la clarificación de hechos históricos, el derecho también es un instrumento relacionado con el enjuiciamiento de hechos acaecidos en el pasado. Esto es inevitable. La historia no es sólo propiedad de los historiadores ${ }^{47}$, sino también de otras ciencias sociales, entre las que se encuentra el derecho. El debate legítimo sobre cuál sea el papel y los métodos específicos de cada una de esas ciencias no debe llevar, a nuestro juicio, a mantener la postura de que el derecho no deba intervenir en materias históricas porque los jueces al valorar hechos y pruebas están haciendo juicios de valor (como se verá al analizar la sentencia del TEDH, Perinçek c. Suiza). Concretamente las legislaciones europeas que prohíben la negación o

45 Decisión de inaceptabilidad del TEDH, Le Pen contra Francia (déc), n. ${ }^{\circ}$ 18788/09, de 20 de abril de 2010 .

46 Decisión de inaceptabilidad del TEDH, Seurot c. Francia (déc), n. ${ }^{\circ}$ 57383/00, de 18 de mayo de 2004.

47 Imbleau, Martin (2011). «Denial of the Holocaust, Genocide, and Crimes Against Humanity», en Hennebel, L., y Hochmann, T., Genocide Denials and the Law, Oxford, Oxford University Press, p. 235. Quien cita a su vez a Barahoma de Brito, Alexandra. (2001). «Truth, Justice, Memory and Democratization in the Southern Cone», en A. BARAHOMA DE BRITO y otros (eds.), The Politics of Memory-Transitional Justice in Democratizing Societies, Oxford Studies in Democratization, Oxford, p. 160. 
justificación del Holocausto y de otros genocidios penalizan a personas que son realmente racistas, cuya intención es restaurar en la actualidad el régimen nazi y provocar sentimientos antijudíos en la sociedad contemporánea ${ }^{48}$. Es decir, no sólo se penaliza a quienes los cometieron o cometen actos genocidas, sino a quienes desean que se vuelvan a cometer en la actualidad e incitan a ello por motivos racistas. En la calificación de las conductas expresivas es imprescindible que los jueces hagan una valoración sobre el contenido de los discursos y sobre la intención de quienes los expresan. Ello requiere el uso de técnicas de ponderación y de valoración al dar peso a cada una de las cuestiones que deben evaluarse y ponerse en la balanza, lo que exige realizar una interpretación judicial complicada ${ }^{49}$.

El derecho, a través de la legislación y de la judicatura (también de la policía), es decir de los operadores jurídicos, podría estar mejor preparado para detectar esas situaciones con mayor rigor jurídico. Cosa distinta es que aún así, incluso en los casos de verdadera justificación del genocidio o de un discurso de odio resulte difícil probar el delito de un modo adecuado procesalmente. Como contrapartida hay que reconocer también el peligro de una injerencia indebida del Estado, de los legisladores o de los jueces en materias opinables o abiertas a la controversia histórica ${ }^{50}$. A su vez, los jueces deben comprobar si ciertas cues-

48 Véase, por ejemplo, la legislación belga. En 1995, Bélgica introdujo en su derecho penal el delito contra la negación de la Shoah. La ley de 23 de marzo de 1995 castiga «a cualquiera que niegue, trivialice, intente justificar o aprobar el genocidio cometido por el régimen nacionalsocialista alemán durante la Segunda Guerra Mundial». Hasta entonces existía la Ley de 30 de julio de 1981 para reprimir los actos inspirados por el racismo o la xenofobia, llamada «Ley Moureaux». Más tarde entro en vigor la Ley de 10 de mayo de 2007 modificando la ley de 30 de julio de 1981 para reprimir ciertos actos inspirados por el racismo y la xenofobia. DUBUISSON, Françoise (2007). «L'incrimination générique du négationnisme est-elle conciliable avec le droit à la liberté d'expression?». Revue de la Faculté de Droit, Université Libre de Bruxelles, volumen 35, 1 Semestriel, pp. 135-195. Bertrams Kenneth y DE Broux, Olivier (2007). «Du négationnisme au devoir de mémoire: l'histoire est-elle prisonnière ou gardienne de la liberté d'expressión?». Revue de la Faculté de Droit, Université Libre de Bruxelles, volumen 35, 1 Semestriel, pp. 75-134. Tulkens, Françoise (2008). «Les relations entre le négationnisme et les droits de l'homme. La jurisprudence de la Cour Européenne des droits de l'homme», en Law in the Changing Europe/Le droit dans une Europe en changement. Liber Amicorum Pranas Kuris, Mykolo Romerio Universitetas, Vilnius, pp. 425-445. AA. VV. (2007) Les propos qui heurtent, choquent ou inquiètent, Revue de la Faculté de Droit, Université Libre de Bruxelles, volumen 35, 1 Semestriel.

49 A mi juicio una sentencia ejemplar es la fallado por el juez Gray en la denuncia por difamación de Irving cv. Lipstadt. Véase sobre el caso, Pérez de la Fuente, Óscar (2010). «Sobre el holocausto: el imperativo de la memoria en el ámbito del derecho y de la historia», AFDUDC, 14, pp. 91-119.

50 FronZa, Emanuela (2011). «The Criminal Protection of Memory: Some Observations About the Offence of Holocaust Denial», en Hennebel, L., y Hochmann, T., Genocide Denials and the Law, o.c., p. 175, epígrafe «The Judge as Historian?». 
tiones forman parte de la verdad histórica o no, con independencia de que la historia también progresa y avanza en la búsqueda de nuevas evidencias. En este sentido compartimos la tesis de Oscar Pérez de la Fuente, según el cual: «A pesar de las perspectivas postmodernas, podemos defender que existe una noción de verdad histórica, unos requerimientos metodológicos para la comunidad científica y una ética y responsabilidad en la investigación. Entonces la estrategia contra los negacionistas y revisionistas es, primero, no considerarlos seriamente, y, segundo, denunciarlos» ${ }^{51}$.

En suma, la adopción de leyes nacionales de algunos Estados europeos de una infracción penal convirtiendo en delito la negación y/o justificación de la Shoah ha suscitado numerosos debates, en relación con el impacto de esta criminalización sobre la libertad de investigación en Historia, sobre el papel del Estado en la definición de la verdad histórica y, de un modo más general, sobre la protección de la libertad de expresión e investigación. Este debate ha sido reactivado recientemente por la adopción de textos jurídicos internacionales y nacionales que intentan extender el campo del delito de negacionismo a otros genocidios, como otros crímenes contra la humanidad u otros crímenes de guerra, definidos de un modo genérico, con falta de precisión de técnica-jurídica.

Un examen detenido de las legislaciones nacionales lleva a la conclusión de que han sido concebidas como un instrumento de lucha contra el racismo y en ese contexto, siempre que cumplan con una serie de requisitos, han sido consideradas en su ámbito nacional compatibles con el principio de libertad de expresión. De hecho varias de esas normas se han visto confrontadas en pronunciamientos de altos tribunales, especialmente de tribunales constitucionales para determinar su compatibilidad o no con las propias constituciones nacionales ${ }^{52}$, llegando a la conclusión en todas ellas de que entraban dentro de lo permitido constitucionalmente y dentro de los límites jurídicos que se podían imponer a la libertad de expresión ${ }^{53}$. En estos casos se persiguen ideas indudablemente, pero ideas o doctrinas cuya intención es racista y que aunque sea indirectamente vulneran a personas individuales, a grupos o incluso a los ciudadanos en general, es decir van contra el inte-

51 Pérez de la Fuente, Óscar. (2010). o.c., texto del abstract que se desarrolla también en la conclusión en la p. 117.

52 Esto ha ocurrido entre otros países europeos, como por ejemplo en Francia, Bélgica, Alemania y España (ya citada). Conseil Constitutionnel, Decisión n. ${ }^{\circ}$ 2012-647 DC de 28 de febrero de 2012. Cour Constitutionnelle Belga, Sentencia n. ${ }^{\circ}$ 45/96, de 12 de julio de 1996. BVerfGE, 2 BVR 197/83, BVerfGE 45, 187, BVerfGE 2 BVL 1/97, BVerfGE 90, 241-255, BVerfGE 2 BvE 2/082.

53 Si bien estas decisiones constitucionales y las propias legislaciones también siguen recibiendo numerosas críticas dentro del mundo jurídico por quienes consideran que la libertad de expresión es prioritaria a toda costa en una sociedad democrática. 
rés general o el orden público o la paz social. Según Imbleau, hay mala fe por parte de los revisionistas ${ }^{54}$, víctimas directas o indirectas y vulneración de bienes jurídicos, que merecen ser protegidos penalmente. Para justificar su necesidad y elaborar ese delito penal al ser el derecho penal la última ratio, la tipificación del delito y la redacción del texto normativo requiere una absoluta precisión, extremo que no siempre cumplen las legislaciones nacionales europeas vigentes.

Es loable que exista un intento de armonización, a través de la nueva normativa del Consejo de Europa, así como la Decisión Marco de la Unión Europea, pero al mismo tiempo debe evitarse el peligro de injerencias desmedidas de los Estados en los derechos de libertad de expresión y de manifestar las propias opiniones, al sugerir que los Estados amplíen la penalización a la negación o trivialización de otros genocidios y de crímenes de guerra, en países con situaciones históricas muy distintas. Además si las normas nacionales utilizan conceptos abiertos y jurídicamente indeterminados en temas penales esto puede conducir a abusos en denuncias no adecuadamente fundadas por parte de los ciudadanos, así como a arbitrariedad en su aplicación por parte de los tribunales. También se presta a la inseguridad jurídica el hecho de que el contenido de la conducta criminalizada no esté claramente definido.

La consecuencia de legislar en materias penales con textos ambiguos, visto lo ocurrido en estos últimos años, es que esos tipos penales acaben siendo inaplicados o que conductas con clara intención racista no sean perseguidas ${ }^{55}$. En

54 Imbleau, M., o.c, pp. 255-267. Véase Hocmann, Thomas, o.c., p. 295, quien expone que en el juicio de Irving contra la editorial Penguin y la escritora Lipstadt por el libro escrito por esta última en el que calificaba a Irving como negador del holocausto, la defensa de Lipstadt utilizó el argumento de la mala fide de Irving. Reino Unido, High Court of Justice (Queen's Bench Division), Irving v. Penguin Books and Deborah Lipstadt, Juez Gray, 11 de abril de 2000, EWHC QB 115.

55 Muchos informes de la ECRI sobre países miembros del Consejo de Europa aportan los datos de las pocas ocasiones en que se aplican estos tipos penales. Aunque exista legislación contra el racismo o el agravante de incitación racial pocos jueces hacen uso de ellos. Por ejemplo, en mi visita a Suiza para la redacción del informe de la ECRI de 2014, véase ECRI Report on Switzerland (fith monotoring cycle): adopte don 19 June 2014, published on the 16th September 2014, conocí dos asuntos, uno referido a la denuncia administrativa y otro vía penal de un partido político (Junje SVP del Cantón de Berna) por sus carteles, en el primer caso se mostraba un negro en una hamaca, tomándose un refresco, en el que se dice «ninguna naturalización para los criminales y los receptores de ayudas sociales» (Keine Einbürgerung von Kriminellen und Sozialhilfeempfángern!). En la decisión administrativa, el Director de la Administración del cantón de Berna (Leitender Staatsanwalt) afirma que no se puede calificar el cartel como un acto racista según lo previsto en el artículo 261 bis del Código Penal suizo porque para serlo debería estar dirigido a un grupo vulnerable concreto y perfectamente identificable, y que en este caso, la persona caricaturizada en el cartel podría ser un africano, un sudamericano, un centroamericano, un mediterráneo, 
ocasiones resulta problemático encontrar la formulación jurídicamente adecuada para condenar a estas personas y por otra parte los tribunales se han visto desafiados por los problemas de prueba de la intención racista.

En los datos estadísticos oficiales que los Estados del Consejo de Europa deben de recoger sobre el número de casos de denuncias penales por motivos racistas se comprueba que muchos Estados aplican en pocas ocasiones este tipo de motivación y/o de agravante, y esto en delitos con uso de violencia y lesiones. Si eso es así en conductas cuya calificación no ofrece lugar a dudas, la persecución penal de ideas o doctrinas racistas engendra todavía más problemas para su puesta en práctica.

Las legislaciones actuales de los países miembros del Consejo de Europa en relación con la penalización de la negación o justificación del Holocausto son muy diversas y obedecen a razones históricas. Alemania, Austria, Bélgica, Francia, los Países Bajos y Rumania condenan la sólo negación del Holocausto y de los crímenes nazis. No se necesita demostrar intención racista. España en el Código Penal de 1995 condenaba la negación o justificación. Después de la sentencia del Tribunal Constitucional de 2007 la mera negación fue anulada como delito. Para volver a ser reincorporado en la reforma de 2015. Otro segundo grupo de países como Dinamarca, Finlandia, Suecia y Reino Unido no penalizan la negación de hechos históricos. Se da la circunstancia de que ninguno de estos países sufrió directamente la ocupación nazi, además de otras razones en el caso de Reino Unido de pertenecer a la tradición de la Common Law y no al derecho continental. Un tercer grupo de países, como Polonia y República checa, condenan la negación de crímenes nazis y de los crímenes comunistas. Un cuarto grupo de países, como Andorra, Chipre, Hungría, Letonia, Lituania, Macedonia, Liechtenstein, Luxemburgo, Malta; Eslovaquia, Eslovenia y Suiza crimina-

pero también un cubano, o una persona de otra raza (Staatsanwaltchaft des Kantons Bern, Verfügung, BM 11 35647/P36, Berna, 17 de octubre de 2011). En el segundo asunto, una sentencia de la Corte Suprema del Cantón de Berna, sección penal, el juez rechaza también la calificación como delito de racismo de un cartel del mismo partido, SVP, en el que se dice «Kosovaren schlitzen Schweizer auf!. Masseneinwanderung stoppen! (¡Los kosovares ponen un cuchillo en la garganta a un suizo! ¡Hay que parar la emigración masiva!). Este cartel relata un hecho concreto, de un kosovar que amenazó con un puñal a un suizo en un parque y extrapola la situación criminalizando a todos los kosovares. En el fallo se afirma que no hay una relación necesaria entre la primera y la segunda frase y se utiliza el principio «in dubio pro duriore» para no calificar el cartel como racista (Beschluss, BK 12376 HAA, Oberricht des Kantons Bern/cour Suprême du canton de Berne, Section pénale, Chambre de recours pénale). 
lizan la negación de todo genocidio. Esta última no exige para que se de la conducta delictiva que esa negación de un genocidio esté hecha de una manera susceptible de incitar a la violencia o al odio ${ }^{56}$.

\section{EL NEGACIONISMO REVISIONISTA NO DEBERÍA ESTAR PROTEGIDO POR EL DERECHO A LA LIBERTAD DE EXPRESIÓN Y DE INVESTIGACIÓN}

El negacionismo y/o justificación del Holocausto se debe encuadrar jurídicamente como una forma especial de discurso de odio. Según la legislación europea el negacionismo es la manipulación ilegítima de la Historia con fines políticos de tal manera que determinados acontecimientos históricos aparezcan distorsionados exculpando a los protagonistas de los mismos. El negacionismo reviste en ocasiones la forma de revisionismo histórico. Este último sería el estudio y reinterpretación de la Historia, que se ocupa de la corrección legítima del conocimiento existente sobre un hecho histórico.

El negacionismo, se considera una práctica pseudocientífica. Los negacionistas del Holocausto nazi se presentan a si mismos como historiadores revisionistas. El dato cierto es que, con la excepción de Irving, ninguno de ellos es historiador ${ }^{57}$. Garaudy condenado en Francia era filósofo (ver infra). De hecho, el Tribunal Europeo de Derechos Humanos nunca ha confundido a un historiador académico con un negacionista neonazi y tampoco a la inversa.

A diferencia de la propaganda, que apela a las emociones, el negacionismo pretende apelar al intelecto, usando varias técnicas ilegítimas para proponer un punto de vista ${ }^{58}$. No se trata, por tanto, de una reinterpretación de los hechos

${ }^{56}$ Cfr., TEDH, Peçinek c. Suiza, n. ${ }^{\circ} 256$ y Teruel Lozano, G. (2015). La lucha del Derecho contra el negacionismo: una peligrosa frontera, o.c, Capítulo 4: «El delito de negacionismo en las principales democracias occidentales», pp. 169-209, sobre Alemania, Francia y Bélgica y pp. 209-222, sobre la legislación antinegacionista en el resto de Estados miembros de la UE. En el caso de Irving fue paradójicament el mismo quien demando por líbelo ante los tribunales civiles británicos a la historiadora Lipstadt y no al revés.

57 En el caso del español Pedro Varela Geiss sí que es cierto que es licenciado en historia, pero no es un académico, sino dueño de la librería «Europa». Véase, Í̃̃̃go CorrozA, E., (2011). «Caso de la librería Europa», en SÁnchez-Ostiz Gutiérrez (Coord.), Casos que hicieron doctrina en Derecho penal, La Ley, Madrid, pp. 613 y ss.

${ }^{58}$ Los argumentos del filósofo negacionista Garaudy en su defensa ante el TEDH son un buen ejemplo de la estrategia usada por los negacionistas. Roger Garaudy c. Francia, n. ${ }^{\circ}$ 6531/01, CEDH, Sección cuarta, decisión sobre la admisibilidad, 24 de junio de 2003. Según este autor, las cifras de judíos que murieron en Auschwitz no es de seis millones, sino de dos tercios menos, pero que lo aporta solo con el objetivo de demostrar que el horror del genocidio nazi no reside en las cifras, sino «en los 
conocidos, sino de la negación de los hechos probados. En opinión de Martin Imbleau el único objetivo de los negacionistas es racista ${ }^{59}$.

Concretamente intentan crear odio contra los judíos que viven hoy entre nosotros. No es una casualidad que a través de los informes de la Comisión contra el racismo y la intolerancia en Europa sobre cada uno de los 47 Estados miembros últimamente se recojan hechos violentos contra las minorías judías en Europa, asaltos y profanación de cementerios y sinagogas ${ }^{60}$. Precisamente lo que originó en Francia la creación de una legislación expresa criminalizando la justificación de crímenes contra la humanidad fue la profanación de un cementerio judío ${ }^{61}$. Lo mismo ocurrió en Alemania.

Las tesis principales de los negacionistas se podrían resumir del siguiente modo; los judíos no fueron asesinados en cámaras de gas: los Nazis no tuvieron una intención de exterminar a los judíos europeos; sus muertes fueron consecuencia de actos individuales, no de obediencia a una misma autoridad; la cifra de seis millones es exagerada; no existieron las cámaras de gas o en caso de existir no se usaron para matar personas: el Holocausto es un mito inventado por los Aliados y/o por los judíos para obtener apoyo económico para crear el nuevo

sufrimientos injustos», que no son «negables» (punto 6. e). En cuanto a las cámaras de gas alega que él cita estudios serios como los del ingeniero Leuchter (punto f), que esto no puede considerarse un acto negacionista, que cuando usa el término «el negocio de la Shoa» no lo hace para negar el genocidio (n. ${ }^{\circ}$ 8). Invoca el artículo 14 del Convenio sobre igualdad de trato para decir que es injusto que se haya dado un tratamiento preferencial a los judíos en detrimento de otros grupos igualmente perseguidos, como los gitanos, lo homosexuales, los eslavos, los armenios y los Tutsis (n. $\left.{ }^{\circ} 10\right)$. Se queja de ser víctima de discriminación por haber sido condenado por el uso del término «lobby judío» (n. $\left.{ }^{\circ} 11\right)$.

59 Imbleau, M. op. c., p. 235.

${ }^{60}$ Cfr., Informes disponibles en la página web de la ECRI, http://www.ecri.org

Lo que se da en paralelo al incremento de islamofobia a raíz del 2001, por causas distintas. Si bien los movimientos neonazis también suelen estar en contra de los inmigrantes en general, incluidos los de origen musulmán, cosa distinta es que su objetivo antiisraelí lleve a curiosos maridajes entre neonazis y gobiernos islamistas como el de Irán.

${ }^{61}$ PECH, Laurent (2011). «The Law of Holocaust Denial in Europe», en Hennebel, L., y Hochmann., T., Genocide Denials and the Law, op. c., p. 199 (pp. 183-226). El incidente consistió en que en mayo de 1990, en la ciudad de Carpentras al sudeste de Francia, cerca de Avignon, un cementerio judío fue profanado. Seis individuos, conocidos por su simpatía hacia los neonazis fueron condenados. La llamada Ley Gayssot, Ley n. ${ }^{\circ}$ 90-6615, introdujo en Francia el 13 de julio de 1990, una sección 24 bis en la Ley de Libertad de prensa de 1881, con una pena de prisión de un año o una multa de 45.000 euros a quien niegue (contester) la existencia de uno o más crímenes contra la humanidad según está definido en el artículo 6 del estatuto del Tribunal Militar Internacional anexo al Acuerdo de Londres del 8 de agosto de 1945 que haya sido cometido bien por miembros de una organización declarada criminal bajo el artículo 9 del Estatuto o por una persona hallada culpable de tales crímenes por un tribunal francés o internacional. 
Estado de Israel ${ }^{62}$ : intentan invertir la carga de la prueba y hacen de las víctimas los verdugos y no aceptan los múltiples testimonios de los supervivientes o de los que protagonizaron hechos innegables ${ }^{63}$.

Las tácticas de los negacionistas son en todas partes las mismas. Cuando no consiguen negar los hechos, intentan minimizarlos o justificarlos. Todo ello es una cadena de comportamientos, en los que la negación es sólo una primera estrategia. No se puede separar ambas actitudes porque van unidas. Algunos académicos, como Guy Haarscher, Alastuey, Rey Martínez, piensan que no se puede penalizar a nadie por el hecho de que niegue un genocidio, ya que eso no significa justificarlo, porque de hecho si lo está negando para él nunca existió ${ }^{64}$. Esto es una hipótesis teórica que no responde al modo de actuar de los negacionistas. Ellos saben perfectamente que esos hechos han existido y su finalidad última es justificar el régimen Nazi para restaurarlo en la actualidad y también denigrar a las personas judías. Establecer esa presunta línea de distinción entre el hecho de que niegan la existencia de un genocidio de buena $\mathrm{fe}^{65}$ porque lo creen así no responde de ningún modo al perfil de neonazis que han sido objeto de condenas penales en toda Europa y cuyas demandas contra sus respectivos Estados han sido negadas por la Comisión de Derechos Humanos o el Tribunal Europeo de Derechos Humanos. En el memorándum que acompaña al Protocolo del Convenio sobre cibercriminalización relativo a la penalización de actos de naturaleza racista y xenófoba cometidos a través de sistemas informáticos se señala: «Estos últimos años, han sido tratados en los tribunales nacionales diversos casos en los que algunas personas (en el ámbito público, en los medios de comunicación, etc) han elaborado ideas o teorías que tienen como finalidad minimizar, negar o justificar los graves crímenes cometidos durante la Segunda Guerra Mundial (en particular el Holocausto). La motivación de tales conductas es a menudo presentada bajo el pretexto de la investigación científica, cuando en

${ }^{62}$ Cfr., Irving v. Penguin Books Limited, Deborah E. Lipstadt [2000] EWHC QB 115 (April 11, 2000), par. 8.4. Cfr., Imbleau, Martin (2011). «Denial of the Holocaust, and Crimes Against Humanity. A Comparative Overview of Ad Hoc Statutes», en Genocide Denials and the Law, op. c., p. 240.

63 Imbleau, Martin (2011). «Denial of Holocaust, Genocide, and Crimes Against Humanity: A Comparative Overview of Ad Hoc Statutes», en Genocide Denials and the Law, o.c., p. 237.

${ }^{64}$ En las obras ya citadas. Por ejemplo, Fernando Rey Martínez aboga por primar la vía de las sanciones administrativas o la imputación de responsabilidades civiles por difamación o por lesión del derecho al honor, en REY, F., «Discurso del odio y racismo líquido». (2015), en REvENGA, Miguel (DIR.), Libertad de expresión y discurso del odio, Universidad de Alcalá, Servicio de Publicaciones, pp. 51-88.

65 Hocmann, Thomas (2011). «The Denier Intent», en Genocide Denials and the Law, op.c., p. 283. Describe la psicología del negacionista. 
realidad la finalidad exacta es apoyar y alentar la motivación política que dio lugar al Holocausto. Además, estas conductas han inspirado también e incluso estimulado y desarrollado las actividades ilegales de grupos racistas y xenófobos, incluido a través de sistemas informáticos. La expresión de estas ideas insulta (la memoria) de toda persona que ha sido víctima del Holocausto, así como a su familia. Se atenta además contra la dignidad de la comunidad humana» ${ }^{66}$.

Otro error común es pensar que estamos hablando de la mera negación de hechos históricos. Las legislaciones que han penalizado estos delitos lo que han criminalizado es la negación o justificación de genocidios, cuando su intención es restaurarlos en la actualidad, no la mera negación de hechos históricos. De hecho es bastante difícil pretender que los negacionistas exponen hechos sin emitir opiniones ${ }^{67}$.

También resulta ingenuo pensar que nos encontramos ante un tipo de personas con las que se puede dialogar y argumentar. Los negacionistas parten de prejuicios y no les interesa el diálogo ${ }^{68}$. Su objetivo es la difusión de ideas o doctrinas racistas, intentando adoctrinar.

En realidad este dilema que se presenta como un conflicto entre el derecho de libertad de expresión y los derechos de otros, es un tanto falso porque el negacionista no pretende tan solo dar un tipo de opinión sobre un hecho del pasado, sino que su objetivo es despreciar directamente a seres humanos. Tolerar el negacionismo sería equiparable a tolerar que alguien niegue la existencia de la esclavitud en el pasado con la idea de rehabilitar esta práctica en nuestros días. Por otro lado, el insulto está protegido por la libertad de expresión (STEDH, caso Otegui c. España), pero el que mantiene ideas genocidas va mucho más allá porque su intención es eliminar a seres humanos o animar a otros a que lo hagan.

${ }^{66}$ Memorándum explicativo que acompaña al Protocolo que acompaña al Convenio sobre Cibercriminalización relativo a la penalización de actos de naturaleza racista y xenófoba cometidos a través de sistemas informáticos.

${ }^{67}$ FranZa, Emanuela, o.c., p. 177. Mantiene que es muy difícil distinguir entre hechos y opiniones.

${ }^{68}$ Cfr., Hocmann, Thomas (2011). «The Denier Intent», en Genocide Denials and the Law, o.c. Como se comprueba en los informes de la ECRI sobre diversos países del Consejo de Europa, no hay ningún tipo de razonamiento lógico en la conducta cada vez más violenta de los grupos de hinchas en el fútbol que asumen una ideología neonazi. Es sabido también que el librero neonazi español Pedro Varela Geiss se negó a participar en cursos sobre el judaísmo durante su estancia en prisión. Cfr.. GARCía, Jesús (2012). «El nazi Varela siembra cruces gamadas en prisión», El País, 15 de enero de 2012. Consultado el 16 de enero de 2013: «Los responsables de la prisiones pensaron que sería buena idea que participase en cursos y charlas con la comunidad judía y organizaciones antirracistas». Disponible en: http://elpais.com/diario/2012/01/15/domingo/1326603160_850215.html 
De hecho en el genocidio de Ruanda quedó sentado por el tribunal que las palabras también pueden ser asesinas ${ }^{69}$.

Desde 1980 varios países de la Europa continental han evolucionado en la persecución de los delitos de odio racial, yendo desde una prohibición genérica del discurso del odio a la elaboración de normas concretas penalizando la negación o justificación del Holocausto y/o otros genocidios y/o de crímenes contra la humanidad. Lo mismo está ocurriendo en los instrumentos internacionales, lo que está llevando a crear una soft-law, que intenta marcar unas pautas comunes, especialmente en Europa. Muchas de ellas no penalizan sólo la negación, sino la trivialización ofensiva o banalización de esos genocidios o su apología.

\section{LA DEFINICIÓN DE GENOCIDIO EN LOS INSTRUMENTOS DE NACIONES UNIDAS Y LA DIFERENCIA CON LOS CRÍMENES CONTRA LA HUMANIDAD}

Todo genocidio es un crimen contra la humanidad, pero no todo crimen contra la humanidad es un genocidio. El genocidio posee un dolus specialis, una intencionalidad específica, por la intención de destruir total o parcialmente a un pueblo. Las víctimas se eligen por su pertenencia a un pueblo, grupo o religión, no por sus cualidades individuales. El tipo penal consta de dos elementos: el mens rea genocida (la intención de destruir un pueblo por motivos étnicos, raciales y religiosos), el actus reus, los actos persigan o consistan en la destrucción de todo un pueblo o grupo.

Muchas conductas son crímenes contra la humanidad porque no puede acreditarse que la intención sea destruir a todo un pueblo, incluso en delitos de limpieza étnica. En otros casos se califican como crímenes contra la humanidad porque a quien se destruye es a un enemigo ideológico o político, pero no se le elige por un motivo racial o religioso (por ejemplo, crímenes en la dictaduras militares argentinas).

Las primeras definiciones de crímenes contra la humanidad se encuentran en los artículos 6b y $6 \mathrm{c}$ del Estatuto del Tribunal Militar Internacional (IMT) en

${ }^{69}$ Cfr., Prosecutor v. Nahimana, Barayagwiza, E Ngeze. Case n. . ICTR 99-52-T. Judgment and Sentence. en http://www.ictr.org. International Criminal Tribunal for Rwanda, December 3, 2003. Comentario a la sentencia por MACKINNON, Catherine. (2004). «International Decisions. Prosecutor v. Nabimana, Barayagwiza, E Ngeze ». American Journal of International Law, vol. 98, January, pp. 325-330. De la misma opinión es LóPEZ-Sidro, Ángel (2013). o.c., p. 99, quien recoge el siguiente texto del historiador Paul Johnson: «una de las principales lecciones de la historia judía ha sido que los repetidos agravios verbales tarde o temprano aparecen seguidos por actos de violencia física». Paul Johnson (2006). La historia de los judíos, Barcelona, p. 850. 
Núremberg (1945). Pero este Estatuto diferencia entre crímenes contra la paz, crímenes contra la humanidad y crímenes de guerra, sin que cree todavía un tipo delictivo propio definido como genocidio, sino que lo incluye dentro de las conductas descritas en el tipo de crimen contra la humanidad. A lo largo del juicio y de modo jurisprudencial los delitos cometidos en el Holocausto fueron tratados como crímenes contra la humanidad y crímenes de guerra bajo el Estatuto del IMT. En los juicios de Nuremberg los perpetuadores del Holocausto no fueron tratados como genocidas porque el Estatuto del IMT no contenía aún la categoría de genocidio. Pero a lo largo de los juicios esta acepción fue creada jurisprudencialmente por el Tribunal de Nuremberg para designar el exterminio de judíos y distinguirlo del resto de «crímenes contra la humanidad».

La Asamblea General de las Naciones Unidas fue la primera que afirmó que el genocidio era un crimen bajo la ley internacional en la Resolución 96 (I) («El crimen de Genocidio» 11 de diciembre de 1946). No obstante, el genocidio es un crimen que solamente existió legalmente con la adopción de la Convención para la prevención y sanción del Genocidio en 1948 y su entrada en vigor en 1951, en su artículo 2, que es la primera definición con fuerza legal de genocidio. Desde la vigencia de dicha Convención el Holocausto de 1939-1945 es llamado oficialmente «genocidio». En realidad es una calificación con carácter retroactivo porque la Convención sobre el Genocidio fue redactada precisamente debido a las atrocidades nazis.

Posteriormente, las definiciones internacionalmente aceptadas, que se ajustan a la Convención mencionada de 1948, son las del Estatuto de la Corte Penal Internacional de 1998, en artículo 6 para el genocidio (cuya definición es idéntica a la del artículo 2 de la Convención sobre el genocidio), artículo 7 para los crímenes contra la humanidad (cuya definición es el texto reescrito del IMT), y el artículo 8 para los crímenes contra la guerra (basada en la Convención de Ginebra de 1949 y los protocolos adicionales de 1977).

Esta distinción ha sido confirmada por el Estatuto del Tribunal Penal Internacional, adoptado en Roma en 1998. En esta norma internacional se consolida la diferencia entre genocidio y crimen contra la humanidad en sus artículos $6^{70}$ y 7 respectivamente. En el genocidio existe una intención de destruir (exterminar) total o parcialmente un grupo concreto por un motivo racial, étnico o reli-

70 Artículo 6 del Estatuto del Tribunal Penal Internacional: «cualquiera de los siguientes actos cometidos con el propósito de destruir, total o parcialmente, a un grupo nacional, étnico, racial o religioso: matar a miembros del grupo; causar graves daños físicos o mentales a miembros del grupo; imponer deliberadamente al grupo unas condiciones de vida que provoquen su destrucción física total o parcial; imponer medidas encaminadas a impedir los nacimientos dentro del grupo; transferir por la fuerza niños pertenecientes al grupo a otro grupo». 
gioso. La finalidad es aquí determinante. De ahí que una primera cuestión de técnica jurídica y que diferencia en este punto de un modo absoluto el derecho de la historia es que sólo se puede usar en puridad legal el término de genocidio para aquellos delitos que hayan sido reconocidos por tribunales internacionales y después de 1948.

El artículo III c) de la Convención sobre el genocidio impone a los Estados parte penalizar «la incitación directa y pública a cometer genocidio». En relación con la jurisprudencia del TPIR en relación con este tema, aunque según el contexto la distinción no es siempre perfectamente neta, hay a pesar de ello una diferencia considerable entre la incitación directa o indirecta a cometer el genocidio y el discurso del odio.

El Comité de la ONU para la eliminación de la discriminación racial, órgano encargado de supervisar la aplicación de la Convención contra la eliminación de la Discriminación Racial (CEDR) ha recomendado que «la negación o las tentativas públicas de justificar los crímenes de genocidio y crímenes contra la humanidad sean declarados punibles por la ley, a condición de que constituyan claramente un acto de incitación al odio o a la violencia racial», subrayando que «la expresión de opiniones sobre hechos pasados no debe estar prohibida, ni castigada ${ }^{71}$. Sin embargo, el artículo 1 de la Convención sobre el genocidio no implica necesariamente que haya obligación por parte de los Estados de incluir un delito penal sobre el discurso del odio ${ }^{72}$.

El artículo 20 § 2 del Pacto Internacional de Derechos civiles y políticos no exige expresamente y sin equívoco la criminalización de la negación del genocidio en tanto que tal, sino que exige la prohibición de toda llamada al odio nacional, racial o religioso que constituya una incitación a la discriminación, a la hostilidad o a la violencia ${ }^{73}$. En 2011, el Comité de Derechos del Hombre de la ONU, órgano internacional encargado de vigilar la aplicación del PIDCP, ha dicho que: «Las leyes que criminalizan la expresión de opiniones que conciernen a hechos históricos son incompatibles con las obligaciones que el PIDC impone a los Estados parte en lo que concierne al respeto de la libertad de opinión y libertad de expresión y que el PIDCP no permite las prohibiciones generales de la expresión de una opinión errónea o de una interpretación incorrecta de hechos del pasado, que las restricciones no deben ser jamás impuestas a la libertad de opinión y, en lo que concierne a la libertad de expresión, las restricciones no deben ir más allá de lo que está permitido por el párrafo 3 (del artículo 19) o lo

${ }^{71}$ Cfr., STEDH, Perinçek c. Suiza, n. ${ }^{\circ} 261$.
${ }_{72}$ Cfr., STEDH, Perinçek c. Suiza, n. ${ }^{\circ} 264$.
${ }_{73}$ Cfr., STEDH, Perinçek c. Suiza, n. ${ }^{\circ} 265$.
(C) UNED. Revista de Derecho Politico N.o 98, enero-abril 2017, págs. 251-334 
exigido por el artículo 20 y que un límite que esté justificado por invocación del artículo 20 debe igualmente ser conforme al párrafo 3 del artículo $19 »^{74}$.

Históricamente y de un modo retroactivo es posible reconocer otros muchos genocidios cometidos en la historia, pero en ese caso el término genocidio se usa de un modo diferente al uso jurídico del delito de la negación y/o justificación del genocidio que implica penalizar en la actualidad a personas que hoy justifican el holocausto judío, que lo hacen por motivos racistas, públicamente y que quieren volver a cometer esos mismos delitos en las naciones concretas en las que viven o reinstaurar sistemas totalitarios o bien denigrar a grupos o personas ${ }^{75}$.

No se puede confundir la persecución de quienes cometieron en primera persona los genocidios con la persecución penal de las conductas actuales de negación o justificación del holocausto, con más razón cuando estamos hablando de instrumentos jurídicos penales. En este último caso, hay que distinguir la negación o interpretación de hechos históricos que se hace como parte de la libertad de investigación, frente a quienes niegan o justifican hechos históricos que sucedieron sin lugar a dudas, que fueron delictivos y que se niegan con un afán racista de herir o discriminar a las víctimas o a sus sucesores en la sociedad actual o bien denigran a grupos o personas por temas relacionados con el delito de genocidio, es decir por su pertenencia a un grupo nacional, étnico, racial o religioso.

Delimitar ese marco ayuda a despejar problemas basados en distintos puntos de vista históricos que deben ser objeto de discusión abierta y cuya defensa no es un problema para la democracia. Incluso el derecho tiene otros instrumentos como el derecho civil o del derecho administrativo para perseguir la difamación y la calumnia ${ }^{76}$.

Por otra parte, y en el mismo sentido, el derecho del Consejo de Europa y la jurisprudencia del Tribunal Europeo de Derechos Humanos arrojan algunas luces que resultan útiles para esclarecer cuál es el marco común sobre qué hechos se consideran jurídicamente como genocidios, así como qué conductas pueden tipificarse como justificación del genocidio en la actualidad. Anne Weber en la

${ }^{74}$ Cfr., STEDH, Perinçek c. Suiza, n. ${ }^{\circ} 265$.

75 Esto último afecta también a la legislación de países del Consejo de Europa que han sido comunistas. Por eso algunos de ellos como Hungría, Polonia y República Checa han introducido como delito el reintentar restablecer el comunismo. En muchos otros, como los países bálticos, la polémica sobre el reconocimiento de las víctimas de los crímenes cometidos por Lenin y Stalin sigue al rojo vivo.

76 De esa opinión es Rey Martínez, Fernando. (2015). «Discurso del odio y racismo líquido», en Miguel Revenga (Dir.), Libertad de expresión y discursos del odio, Universidad de Alcalá, Servicio de Publicaciones, pp. 51-88. 
monografía Manuel sur le discours de haine ${ }^{77}$, sintetiza los criterios acordados en la jurisprudencia del TEDH.

\section{LA NORMATIVA DE LA UE}

Tras largos debates ${ }^{78}$, la Unión Europea elaboró la Decisión Marco 2008/913/ JAI (65) del Consejo, de 28 de noviembre de 2008, relativa a la lucha contra determinadas formas y manifestaciones de racismo y xenofobia mediante el derecho penal (DOUE L 328, de 6 de diciembre de 2008). Dicha Decisión considera que el racismo y la xenofobia constituyen una amenaza actual para los 28 Estados miembros de la Unión, que debe llevar a definir un nuevo Derecho penal común a los quinientos millones de seres humanos que integran la Unión Europea, donde se castigue la «apología pública», «negación» o la «trivialización ofensiva» («denying or grossly trivialising») de los crímenes de genocidio y contra la humanidad. Contamos también con la Resolución del Parlamento Europeo sobre memoria del Holocausto, antisemitismo y racismo ${ }^{79}$.

77 Weber, Anne (2009). Manuel sur le discours de haine, Council of Europe, Martinus Nijhoff Publishers, 97 pp.

${ }^{78}$ PeCH, Laurent (2011).«Ruling Denial Prohibition», en Genocides Denial and the Law, op. c., p. 223.

79 El Protocolo Adicional al Convenio sobre Ciberdelincuencia, de 23 de noviembre de 2001, del Consejo de Europa, considera material racista y xenófobo «todo material escrito, toda imagen o cualquier otra representación de ideas o teorías, que propugne, promueva o incite al odio, la discriminación o la violencia, contra cualquier persona o grupo de personas, por razón de la raza, el color, la ascendencia o el origen nacional o étnico, así como de la religión en la medida en que ésta se utilice como pretexto para cualquiera de esos factores» (Artículo 2.1).

El artículo 1 de la Propuesta de Decisión Marco, relativa a la lucha contra el racismo y la xenofobia, aprobada por el Consejo de la Unión Europea en su reunión de 20 de abril de 2007, establece una obligación a los Estados miembros de la Unión Europea de adoptar medidas que garanticen el castigo de la apología pública de los crímenes de genocidio, y también de la negación o trivialización flagrante de los mismos, cuando «la conducta se ejecute de tal manera que pueda implicar una incitación a la violencia o al odio contra el grupo social afectado». Por tanto, para su penalización es necesario que exista el elemento tendencial de incitar al odio. En otras palabras, se requiere la intención y la publicidad.

El criterio que se deriva de la aplicación de este delito en los tribunales nacionales europeos es que para que haya delito basta una incitación al odio racial, que sea indirecta o mediata (no se exige incitación directa). Como indica el Magistrado Ramón Rodríguez Arribas, recogiendo también la opinión del Ministerio Fiscal, «El llamado "negacionismo" es, en sí mismo cuando menos, un claro menosprecio hacia las víctimas que lo sufrieron y así se presenta en cuantas ocasiones se produce en la realidad de quienes sostiene, por ejemplo, que el holocausto no existió y que solo es propaganda sionista; pretender amparar semejantes actitudes en la libertad de expresión es degradarla; por el contrario, y como sostiene el Ministerio Fiscal, dichas actitudes van encaminadas a 
Anteriormente existían ya otras normas, como la Decisión 2000/750/CE del Consejo de Europa de 27 de noviembre de 2000, por la cual se establecía un programa de acción comunitaria para la lucha contra la discriminación (DON L 303, de 2 de diciembre de 2000). A ello se unieron varias Directivas, como la Directiva 2000/43/CE, de 29 de junio de 2000, relativa a la aplicación del principio de igualdad de trato a las personas, independientemente de su origen racial o étnico (DOCE L 180, de 21 de diciembre de 2004). Previamente la Acción Común de 15 de junio de 1996 contra el racismo y la xenofobia establecía la necesidad de castigar penalmente la incitación pública a la discriminación, la violencia o el odio racial, la apología pública de crímenes contra la humanidad, la negación pública del genocidio y crímenes contra la humanidad, cuando ello incluya un comportamiento degradante hacia grupos raciales o étnicos, o la difusión pública de manifestaciones racistas.

Pasamos a analizar algunos de los puntos del texto de la Decisión Marco. En primer lugar, se señala claramente que se penalizarán las conductas intencionadas, ya que se indica expresamente que se castiguen « las siguientes conductas intencionadas». Se requiere incitación a la violencia o al odio contra tal grupo, lo cual implica una intención racista o de incitar al odio o a la violencia, aunque no se menciona la incitación al genocidio. Esta exigencia de intención racista ha sido vista por la doctrina como algo positivo. No obstante, hubiera sido más claro que al término «intencionadas» se añadiera el de «racistas». También podría considerarse insuficiente que se deje en manos de los Estados la posibilidad de penalizar las conductas, «que amenacen, injurien o insulten», si son contrarias al orden público. A juicio de algunos autores, este tipo de conductas deberían haberse incluido como parte de la normativa común vinculante para los Estados de la UE ${ }^{80}$.

hacer surgir estados de opinión tergiversados sobre este hecho histórico, ciertamente contrarios a lo que realmente aconteció, tratando así de fomentar el olvido del mismo, por lo que el precepto no trata de castigar la libre difusión de ideas u opiniones, por muy reprobables y rechazables moralmente que fueran, sino de proteger a la sociedad de aquellos comportamientos que, una sistemática preparación sicológica de la población, a través de los medios propagandísticos, generarían un clima de violencia y hostilidad que, de forma mediata, pudiera concretarse en actos específicos de discriminación racial, étnica o religiosa; ciertamente este es un peligro que una sociedad democrática no puede permitirse correr en las actuales circunstancias, en las que no puede negarse el rebrote de estas actitudes» (voto particular Magistrado Ramón Rodríguez Arribas a la Sentencia del TC, 5152-2000, n. ${ }^{\circ}$ 4, BOE, núm. 295, Suplemento, lunes 10 de diciembre de 2007 , p. 56).

${ }^{80} C f r$. Dubuisson, F. «L'incrimination générique du négationnisme est-elle conciliable avec le droit à la liberté d’expression? », o. c., p. 191. 
También se ha considerado positivo que por lo menos defina un marco legal más preciso sobre cuáles son ese tipo de conductas, a saber: las definidas en el Estatuto de la Corte Penal Internacional, a diferencia de algunos de los códigos penales de Estados miembros de la UE que no las concretan.

Segundo, de todos los supuestos previstos en el artículo 1, los Estados pueden limitar la penalización de esas conductas restringiéndolas a los casos en los que se perturbe el orden público o que sean amenazadoras, abusivas o insultantes. Además, se diferencia entre la justificación de los crímenes definidos en el artículo 6 del Estatuto del Tribunal Militar Internacional de 1948. El art. 1. d) de la Decisión Marco incluye crímenes de genocidio, crímenes de guerra y crímenes contra la humanidad y otros crímenes. Esta extensión del delito a crímenes de guerra y crímenes contra la humanidad ha sido criticada como excesiva por la doctrina penalista y constitucionalista por los problemas que se derivan de su aplicación práctica en el persecución de estos delitos cuando entran en conflicto con la libertad de expresión.

El problema es que dicho Estatuto en sí no concreta, como hemos señalado, la definición de genocidio. Fue en los juicios del Tribunal de Nuremberg donde esto se hizo y en la Convención para la sanción y la prevención del delito de genocidio de la ONU de 1948. Luego en la Decisión Marco se debería de citar esta Convención. Fue en ese Tribunal Internacional, en el que se describió en qué consistían esos crímenes y en el que se imputó la responsabilidad a algunas personas concretas, a las que se condenó.

De ahí que, en mi opinión, la tipificación como crimen de la justificación del genocidio en los códigos penales debería referirse explícitamente al Tribunal de Nuremberg y a la Convención de la ONU y/o concretar en qué consisten exactamente esos delitos.

En resumen, se echa en falta que en la Decisión Marco no se precise a qué crímenes contra la paz, crímenes contra la humanidad, y crímenes de guerra se refiere $^{81}$. Simplemente en su art. 4. se deja como una opción para los Estados que lo deseen su concreción en los siguientes términos: «si los crímenes a los que hacen referencia dichas letras han sido establecidos por resolución firme de un tribunal nacional de dicho Estado miembro o un tribunal internacional, o mediante resolución firme exclusiva de un tribunal internacional», sin restringirlo a los tribunales penales internacionales.

81 En esto coincide, como veremos después, con el Protocolo del Consejo de Europa contra la ciberdelincuencia, con la diferencia de que la Decisión Marco es obligatoria mientras que el Protocolo es optativo. 
Esto debería haberse incluido en el texto del artículo 2 como vinculante, porque entonces los Estados que asuman el art. 2 sin ninguna especificación tendrán los problemas que estamos señalando ${ }^{82}$. Defecto que se detecta ya en algunas de las legislaciones nacionales vigentes, como la Ley francesa Gayssot ${ }^{83}$. Es decir, conforme a esta Ley puede considerarse como delito la negación de determinados hechos históricos que hayan sido crímenes contra la humanidad, sin necesidad de que éstos hayan sido calificados como tales por un tribunal internacional concreto, sino que lo pueden hacer también los tribunales franceses. Otra legislación que ha causado problemas por su inconcreción es la redacción del art. 261 bis del Código Penal suizo, que penaliza la negación de genocidio, lo que analizaremos en el apartado dedicado a la sentencia del TEDH Perinçek. C. Suiza.

En relación con el art. 1. c) de la Decisión Marco, en cuya virtud debe garantizarse el castigo de «la apología pública, la negación o la trivialización flagrante de los crímenes de genocidio, crímenes contra la humanidad y crímenes de guerra tal como se definen en los artículos 6, 7 y 8 del Estatuto de la Corte Penal Internacional, dirigida contra un grupo de personas o un miembro de tal grupo definido en relación con la raza, el color, la religión, la ascendencia o el origen nacional o étnico cuando las conductas puedan incitar a la violencia o al odio contra tal grupo o miembro del mismo» se ha criticado que el adjetivo «pública» figure sólo en el delito de apología y se considera negativo que no se añada ese calificativo a la negación o la trivialización flagrante. Esto también causa inseguridad jurídica porque se deberían penar sólo los actos públicos ${ }^{84}$.

Como contraste, resulta más positivo el criterio del Tribunal Europeo de Derechos Humanos, que establece que el delito sea la negación y/o justificación

${ }^{82}$ Como contraste, según lo que hemos señalado anteriormente, la ley Gayssot criminaliza a quien cuestiones la existencia de crímenes contra la humanidad definidos en el artículo 6 del Estatuto del Tribunal Internacional Militar anexado al Acuerdo de Londres del 8 de agosto de 1945. La legislación francesa considera como una ofensa no la negación del Holocausto, sino poner en cuestión la existencia de crímenes contra la humanidad, que son los específicamente definidos por los actos sentados en el documento histórico legal del Estatuto del Tribunal Militar Internacional. De hecho en la Ley Gayssot no se menciona específicamente el Holocausto, la Shoah o los judíos, sino negar la responsabilidad de individuos o grupos que haya sido declarada por el Tribunal Internacional de Nuremberg o por un Tribunal francés. Véase, Fraser, David. «From Genocide to Denial», en Hennebel L., y Hochmann, T., Genocide Denials and the Law, o.c., p. 21.

83 Véase, Fraser, David. Ibid, pp. 29-30.

${ }^{84}$ Como contraste véase la Recomendación n. ${ }^{\circ} 7$ de la ECRI que exige para su penalización que estas conductas sean públicas. 
de hechos históricos criminales reconocidos y calificados como tales por los tribunales penales internacionales.

Son muchos los académicos europeos que consideran que la negación del Holocausto es diferente a la negación de otros fenómenos históricos cara a su penalización ${ }^{85}$, como pudiera ser el genocidio de los Tutsis o la masacre de los armenios. El primer caso, entra claramente en el tipo penal cuando se incrimina genocidios reconocidos por tribunales penales internacionales, pero quedaría excluido si sólo se acepta el Estatuto del Tribunal Internacional Militar de Londres. Al margen de ello, el genocidio de los Tutsis no es una cuestión que genere debate, hoy por hoy, entre europeos, aunque podría resucitarse si se utilizara contra inmigrantes de esos grupos que vinieron a Europa huyendo de esa guerra. Para ello, si se niegan esos genocidios tendría que ser con intención racista o con la finalidad de rehabilitar los regímenes que dieron lugar a esos hechos en Europa, lo cual resulta bastante improbable ${ }^{86}$. En el caso de negación del Holocausto generalmente se penaliza por realizarlo con ese fin (si bien siempre tendrá que probarse la intención racista) ${ }^{87}$.

El debate sobre la calificación jurídica de la masacre de los armenios en 1915 bajo el Imperio Otomano como genocidio es un tema controvertido entre historiadores y en la realidad social y también en los fallos de diversos tribunales nacionales y en el TEDH, especialmente entre turcos y armenios en sus países de origen y en la diáspora de los primeros y los distintos grupos de inmigrantes turcos fuera de Turquía. Está claro que no ha sido reconocido de momento como genocidio por ningún tribunal internacional. Al margen de ello, si la negación de esas masacres, que sí es un hecho histórico probado, se hace con intención de discriminar a los armenios actuales es posible utilizar otros tipos penales para su persecución, así como la vía civil. En Turquía esta cuestión es absolutamente polémica. El gobierno turco se niega a calificar los sucesos de la primera guerra mundial en relación con los turcos como un genocidio hasta el punto de constituirlo en una cuestión de Estado que afecta a sus relaciones internacionales con

85 Entre los ya citados remitimos a Óscar Pérez de la Fuente y Ángel López-Sidro.

86 Ternon, Yves. (2007). «La négation du génocide: une approche comparative», en B. Lefevbre y S. Ferhadjian (dirs.), Comprende les génocides du XX siècle, Éditions Bréal, Rosny-sous-bois, pp. 154 y ss. Ternon, Yves. (1999).«Négationnismes: règles générales et cas particulièrs», en K., Boustany y D., Dormory, Génocides, Bruxelles, Éditions Bruylant et Éditions de l'Université de Bruxelles, pp. 143 y ss.

${ }^{87}$ Dubuisson, François. «L’incrimination générique du négationnisme est-elle conciliable avec le droit à la liberté d'expression? », o. c., p. 193. 
otros países y a sus propios ciudadanos ${ }^{88}$. Ello ha llevado y sigue causando situaciones graves de convivencia y de discriminación de los armenios que viven en Turquía en algunos momentos álgidos. En principio, los turcos que niegan hoy el genocidio armenio no lo hacen con la intención de volver a restaurar un genocidio contra los armenio-turcos, pero sí es verdad que persiste la discriminación con el uso de la violencia por parte de grupos turcos musulmanes fundamentalistas, en ocasiones con resultado de homicidio. Esto está penalizado en el código penal turco. Por otra parte, los turco-armenios están reconocidos en Turquía como minoría nacional por el Tratado de Lausana con la consiguiente protección que los convenios internacionales otorgan a quienes ostentan el estatuto de minoría ${ }^{89}$. Por lo demás Turquía no es miembro de la UE y no le vincula esta Decisión Marco.

A mi entender, la Decisión Marco común de la UE podría como mucho obligar a penalizar la negación y/o justificación, realizada con intención racista, del Holocausto judío, tal y como se definió en la Convención para la sanción y la prevención del delito de genocidio de la ONU de 1948, pero poco más, ya que cada tipo de negacionismo debería ser tratado de distinto modo, dependiendo de la historia y de la situación de cada país de la UE. Además la penalización no debería ser extendida a otros conceptos sin un contenido histórico definido, como el de crímenes contra la humanidad, o dejándolos abiertos hacia

88 Racine, Jean-Baptiste (2006). Le génocide des Arméniens. Origine et permanence du crime contre l'bumanité, Paris, Dalloz, p. 128. Imbleau, Martin. «Denial of the Holocaust, Genocide, and Crimes Against Humanity», o.c., pp. 298-299.

89 Para datos concretos sobre la situación de Turquía en temas referentes al racismo, véase ECRI, V Report on Turkey, adoptado el 2 de marzo de 2016. Disponible en la web de la ECRI. El artículo 220 del Código Penal turco penaliza la creación y organización de grupos con intención de cometer delitos y el art. 78.1 del CC penaliza la creación o liderazgo de organizaciones con la intención de cometer genocidio u otros crímenes contra la humanidad. El Código Penal no penaliza la expresión pública con fines racistas de una ideología que mantenga la superioridad, o que desprecie o denigre, a un grupo de personas por esos motivos. La negación de pública de crímenes de genocidio y actos similares no está penalizada. El artículo 216.1 del Código Penal persigue la humillación pública basada en la clase social, la religión, la raza, secta u otro origen y el art. 122 cubre algunos casos de incitación a la discriminación y el art. 216 la incitación al odio. En cuanto al discurso racial o de odio, según la Fundación Hrant Dink en su último informe que cubre de septiembre a diciembre de 2014, se recogen 143 actos contra judíos, 115 contra cristianos, 60 contra armenios, 16 contra refugiados sirios, 14 contra griegos, 11 contra occidentales, 8 contra alevis y 7 contra árabes. El grupo objeto de discriminación va cambiando según los hechos acaecidos en acontecimientos internacionales. El antisemitismo actual está relacionado con la política de Israel en Gaza. La cifra de minorías es entre 40.000 a 90.000 armenios, 20.000 judíos y 3.000 griegos, frente a 500.000 mil o 5 millones de gitanos. 
el futuro. Es imposible legislar una lista completa detallando cada uno de las negaciones de genocidios que pueden ser penalizadas. Sin embargo, si en la norma se explicita que sólo se refiere a los genocidios reconocidos por tribunales internacionales, el tipo penal quedaría cerrado y aportaría mayor seguridad jurídica.

Todo ello puede ser abordado desde los otros tipos previstos en los códigos penales de cada país miembro del Consejo de Europa o de la UE, y además con medidas previstas en el derecho civil y en el derecho administrativo cuando se produzcan conductas racistas.

\section{LA NORMATIVA DEL CONSEJO DE EUROPA. EL CONVENIO SOBRE CIBERCRIMINALIDAD RELATIVO A LA PENALIZACIÓN DE ACTOS DE NATURALEZA RACISTA Y XENÓFOBA COMETIDOS A TRAVÉS DE SISTEMAS INFORMÁTICOS Y SU PROTOCOLO ADICIONAL}

El Consejo de Europa ha elaborado el primer tratado internacional jurídicamente vinculante sobre cibercriminalidad, relativo a la incriminación de actos de naturaleza racista y xenófobos cometidos a través de los sistemas informáticos, Convenio n. ${ }^{\circ} 185$, del Consejo de Europa, adoptado por el Consejo de Ministros el 8 de noviembre de 2001, tras negociaciones iniciadas en 1997 y tras una treintena de borradores del proyecto ${ }^{90}$. Firmado en Budapest el 23 de noviembre de 2001, el Convenio entró en vigor el día 1 julio de 2004 ${ }^{91}$.

Señala en su exposición de motivos: «La lucha contra la ciberdelincuencia requiere una cooperación internacional reforzada, rápida y eficaz en materia penal»...«Teniendo presente la necesidad de garantizar el debido equilibrio

90 Pavón Pérez, Juan Antonio (2003). «La labor del Consejo de Europa en la lucha contra la cibercriminalidad: El Protocolo adicional al Convenio n. ${ }^{\circ} 185$ sobre cibercriminalidad relativo a la incriminación de actos de naturaleza racista y xenófobos cometidos a través de los sistemas informáticos», Anuario de la Facultad de Derecho, ISSN 0213-988-X, vol. XXI, 187-204. Aquí p. 194.

${ }^{91}$ La información sobre el estado actual de las firmas, ratificaciones, declaraciones y reservas aparece reflejada en la página web que se indica en esta nota. Como en el caso de todos los convenios del Consejo de Europa, la lista de los instrumentos incluyendo información básica sobre cada uno de ellos (cuadro de firmas y ratificaciones, fecha de entrada en vigor, lista de reservas, declaraciones y comunicaciones por los estados parte, texto íntegro de la convención, resumen de su contenido e informe explicativo) está disponible en los dos idiomas oficiales del Consejo de Europa (francés e inglés) y además en italiano, alemán y ruso en la página web de la organización (http://conventions.coe.int/Default.asp). 
entre los intereses de la acción penal y el respeto de los derechos humanos fundamentales consagrados en el Convenio del Consejo de Europa para la Protección de los Derechos Humanos y de las Libertades Fundamentales (1950), el Pacto Internacional de Derechos Civiles y Políticos de las Naciones Unidas (1966) y otros tratados internacionales aplicables en materia de derechos humanos que reafirman el derecho a defender la propia opinión sin interferencia, el derecho a la libertad de expresión, incluida la libertad de buscar, obtener y comunicar información e ideas de toda índole, sin consideración de fronteras, así como el respeto a la vida privada».

El Protocolo adicional relativo a la penalización de actos de naturaleza racista y xenófoba cometidos por medio de sistemas informáticos (STE 189) fue abierto a la firma en enero de 2003 y entró en vigor el 1 marzo de 2006. A fecha de agosto de 2014 lo han ratificado veinte países ${ }^{92}$.

En primer lugar, dos elementos esenciales a tener en cuenta son los siguientes: que este protocolo es adicional al Convenio del mismo título y que su adición es voluntaria y que a su vez es necesario haber ratificado previamente el Convenio para poderse adherir al Protocolo. La otra cuestión importante es el marco jurídico en el que nos movemos. En este caso, a diferencia de la Decisión Marco de la UE, se encuadra dentro de los delitos informáticos. Por último, hace relación al racismo y la xenofobia.

Este último elemento es crucial para distinguir la persecución de determinadas conductas. Es decir, no se trata de un amplio campo de la discriminación por otros motivos, sino tan sólo la discriminación por cuestión de raza, el color, la ascendencia o el origen nacional o étnico, o de la religión. Toda interpretación de este protocolo adicional y de normas del Consejo de Europa debe hacerse de un modo sistemático, encuadradas en el Convenio Europeo de

92 El protocolo ha sido ratificado por 24 de los 47 Estados miembros del Consejo, y tres han hecho uso de la posibilidad de no aplicar el art. $6 \S 1$. España firmó el Convenio el 23 noviembre 2001 y lo ratificó por instrumento de 20 mayo 2010 (BOE de 17 septiembre 2010) -EDL 2001/97504, y entró en vigor en este país el 1 de octubre de 2010. El Convenio ha recibido la adhesión y la firma de 30 países, y otros 16 lo han ratificado, sin firmarlo. Cfr., http://conventions.coe.int. Albania, Alemania, Armenia, Bosnia-Herzegovina, Chipre, Croacia, Dinamarca, Eslovenia, España (El Gobierno, en Consejo de Ministros de 21 de marzo de 2014 lo remitió a las Cortes Generales). Finlandia, Francia, Letonia, Macedonia, Montenegro, Noruega, Países Bajos, Portugal, Rumania, Serbia y Ucrania. Véase, Eduardo FungaIRIÑo Bringas (Fiscal de Sala del Tribunal Supremo), Prontuario actualizado de convenios de extradición y otros de cooperación judicial internacional penal, Inscrito en el Registro de la Propiedad Intelectual con n. ${ }^{\circ}$ 16/2011/4970. Disponible en web:

https://wikipenal.wikispaces.com/file/view/PACO,\%20HASTA\%202\%20DE\%20 MAYO\%202014.pdf/508338986/PACO,\%20HASTA\%202\%20DE\%20MAYO\%202014.pdf 
Derechos Humanos y Libertades Fundamentales, y en su caso en la jurisprudencia del TEDH.

La propia exposición de motivos ofrece el marco de interpretación necesario al que nos estamos refiriendo: «A efectos del protocolo se define el material racista y xenófobo como todo material escrito, toda imagen o toda otra representación de ideas o de teorías que preconizan o incitan al odio, la discriminación o la violencia, contra una persona o un grupo de personas en razón de la raza, el color, la ascendencia o el origen nacional o étnico, o de la religión, en la medida en que esta última sirva de pretexto para uno u otro de estos elementos y que incite a éstos actos» ${ }^{93}$.

Entre las medidas a tomar, todas ellas, insistimos, están relacionadas con la difusión de material racista o xenófobo a través de sistemas informáticos. La finalidad del Protocolo adicional es que los países que lo firmen tipifiquen estas conductas como infracción penal en su derecho interno, siempre que sean cometidas intencionalmente y con abuso de derecho. Las conductas son las siguientes: la difusión u otras formas de puesta a disposición del público, por medio de un sistema informático, material racista o xenófobo. Si ese material preconiza, alienta o incita a una discriminación que no esté asociada al odio o a la violencia puede no perseguirlo por medios penales, siempre que existan otros medios eficaces para combatirlo. Así y todo, se deja abierta la posibilidad de que el Estado no criminalice estas conductas, incluso cuando no pueda asegurar otros medios para perseguirlas, debido al respeto a la libertad de expresión. Con esta última matización se deja abierta la puerta a que los Estados no penalicen dichas conductas. Luego la obligatoriedad de los contenidos del Protocolo, incluso para los Estados que lo ratifiquen es bastante relativa ${ }^{94}$.

También se deben adoptar medidas legislativas y otras que se consideren necesarias para erigirlas en infracción penal, en el derecho interno, cuando se cometa intencionalmente y sin derecho, la siguiente conducta: la amenaza, por vía informática, de cometer una infracción penal grave, tal y como se defina en el derecho nacional, hacia una persona en razón de su pertenencia a un grupo que se caracterice por la raza, el color, la ascendencia o el origen nacional, étnico o la religión en la medida en que esta última sirva de pretexto a uno u otro de los elementos, o un grupo de personas que se distinga por uno de esas características ${ }^{95}$.

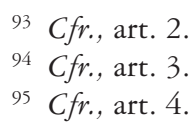


Del mismo modo, y en términos similares se anima a establecer medidas penales para castigar el insulto en público, consideramos crucial este punto, con motivos racistas y xenófobos, siempre a través de vías informáticas de una persona en razón de su pertenencia a un grupo que se caracterice por la raza, el color, la ascendencia o el origen nacional, étnico o la religión en la medida en que esta última sirva de pretexto a uno u otro de los elementos, o un grupo de personas que se distinga por uno de las características recogidas en el art. $5^{96}$. Se añade así un matiz referente al resultado de la conducta que los Estados pueden exigir para penalizarla, a saber que ese insulto tenga por efecto exponer a la persona o al grupo de personas, ya descritas anteriormente, al odio, desprecio o ridículo. La duda es si se exige un efecto directo. Los Estados se pueden reservar el derecho de no aplicar este artículo en su totalidad o en alguna de sus partes. El artículo 6 prevé literalmente: «La negación, trivialización, la aprobación o la justificación del genocidio o de crímenes contra la humanidad».

La interpretación de estos artículos debe hacerse en consonancia con el informe explicativo que acompaña a dicho Protocolo. En él se explicita el significado de los términos difusión y puesta a disposición del público, así como los criterios jurídica para calificar una conducta de privada o pública, si bien será el juez quien habrá de calificar la conducta teniendo en cuenta las circunstancias específicas de cada caso.

Los problemas que plantea la redacción del artículo 6 es que los criterios para decidir que conductas se encuadran dentro del delito de negacionismo no están previamente definidos, sino que se deja al arbitrio de los criterios genéricos establecidos en el Protocolo. Está indeterminación deja una puerta abierta a que los Estados injieran en la libertad de expresión.

La falta de acuerdo entre los Estados ha llevado a que la Convención y el protocolo adicional se hayan adoptado como dos textos jurídicos separados. A su vez la adopción del Protocolo ha suscitado tantas discusiones que al final prácticamente todos sus artículos pueden ser objeto de reserva total o parcial.

En conclusión, el Protocolo ni siquiera obliga a quienes lo firmen a introducir en los códigos penales el delito de negación de genocidio y tampoco a hacerlo extensivo a los crímenes contra la humanidad. Por otro lado, cualquier interpretación debe ser hecha en el contexto del Convenio Europeo de Derechos Humanos y debe respetar el art. 10 sobre derecho a la libertad de expresión. Tampoco es vinculante el criterio que introduce el texto explicativo de la intención de los redactores. El único referente es el criterio sentado por el TEDH sobre «hechos históricos claramente establecidos», qué analizaremos más adelante.

${ }^{96}$ Cfr., art.5. Esto último se repite igual que en el art. 4. 


\section{ALGUNOS PROBLEMAS DE INTERPRETACIÓN DE LA LEGISLACIÓN DEL CONSEJO DE EUROPA Y DE LA UE. LA NO EXIGENCIA DE DEMOSTRAR LA INTENCIÓN RACISTA EN EL CONVENIO SOBRE CIBERCRIMINALIDAD DEL CONSEJO DE EUROPA}

En definitiva, lo que suscita más problemas es la explicación del número 41 de los criterios interpretativos del Protocolo sobre Cibercriminalidad. Como hemos visto también ocurría algo semejante en la Decisión Marco de la UE.

Primero, ya es problemático concretar a qué genocidios se refiere el Convenio n. ${ }^{\circ} 185$, del Consejo de Europa y su Protocolo adicional, con lo cual el problema se agranda hasta límites insospechados si se pretende introducir la criminalización de la justificación de crímenes contra la humanidad y crímenes de guerra. Esto convierte el campo de aplicación del delito en un mar sin orillas. Pensemos por ejemplo sin ir más lejos en los manuales de enseñanza de la historia de primaria y secundaria, no ya en textos escritos por deleznables neonazis. La enseñanza de la historia es un tema controvertido. Concretamente la enseñanza de las dos Guerras Mundiales y los enfoques en los distintos países sigue siendo un tema polémico. Cabe ya con las legislaciones actuales hacer denuncias de textos escolares, pero se suele utilizar la vía civil o la vía contencioso-administrativa y raramente la vía penal.

Si hemos establecido como condición (aunque sea también criticada) el que sean hechos del pasado, deberían limitarse a hechos ocurridos durante el periodo de vigencia de las legislaciones nacionales o internacionales que penalicen estos delitos, evitando el carácter retroactivo. En primer lugar, debe señalarse cuáles hechos del pasado entran dentro de la calificación del delito. Esto no debería de resultar ambiguo.

Por ahora sólo hay pocos hechos históricos reconocidos como genocidios por tribunales internacionales, a saber: el genocidio de Srebrenica y los crímenes contra la humanidad (Estatuto del Tribunal Penal Internacional para la ex Yugoslavia y jurisprudencia del Tribunal $)^{97}$, la jurisprudencia de la Corte Internacional de Justicia ${ }^{98}$, los tribunales especiales y ad hoc, como el Tribunal para Ruanda, que juzga el genocidio de los Tutsis, a mano de los Hutus (Estatuto del

97 TPIY, Le Procureur cl R. Krstic, Chambre de première instance, jugement du 2 août 2001 et Chambre d'appel, arrêt du 19 avril 2004,

http://www.un.org/icty/index-f.html.

98 C. I. J., affaire de l'Application de la convention pour la prévention et la répression du crime de génocide (Bosnie-Herzegovine c. Serbie-et-Monténégro), arrêt du 26 févrie 2007, http://www.icjcij.org 
Tribunal penal internacional para Ruanda y jurisprudencia del Tribunal) ${ }^{99}$, así como el Tribunal mixto para Sierra Leona ${ }^{100}$, el tribunal especial para el Líbano ${ }^{101}$ y el tribunal mixto para Camboya.

Lo que preocupa en Europa es el resurgimiento y reciente crecimiento de partidos neonazis o de extrema derecha. El genocidio nazi fue un crimen reciente, planeado y justificado racionalmente por pseudointelectuales en Europa, no fruto de pasiones de guerra. Por ello, el delito que figura en los actuales códigos penales se refieren expresamente a la «defensa de ideas o doctrinas racistas que justifiquen el genocidio y traten de reinstaurarlo», ya que hoy en día este prejuicio racista es algo irracional y emocional, que se presenta con pseudoargumentos racionales.

El Protocolo cita expresamente la condena de ideas y doctrinas racistas. La dificultad en todo ello, es tanto el tema de la prueba, como la calificación de estos delitos, así como la formación de los jueces y de la policía. La legislación de la UE y del Consejo de Europa debería centrarse en los genocidios cometidos en Europa (incluida la Europa del Este). Lo lógico, si el objetivo es crear una legislación con unas normas mínimas comunes para los países europeos (bien a través de la UE o bien en el Consejo de Europa), sería centrarnos en el pasado europeo.

El hecho de dejar abierto la posible conducta delictiva a sucesos que puedan darse en un futuro y lo que futuros tribunales reconozcan como genocidios, visto desde un punto de vista penal y de seguridad jurídica es absolutamente problemático. Del mismo defecto adolece la Decisión Marco. Definir que se penarán la justificación de genocidios y delitos de guerra, según los define el Estatuto de la Corte Penal Internacional no resuelve las cosas porque ese Estatuto aunque define esos conceptos, no dice que hechos históricos concretos son calificados como tales. Pero es que el Protocolo del Consejo de Europa ni siquiera remite a la norma jurídica que define estos conceptos, aunque tampoco eso resultaría suficiente, porque lo que se castiga es negar genocidios reconocidos por tribunales internacionales. Por otro lado, hay otras muchas situaciones que dependen de cada país y de su historia concreta. No se puede uniformar, ni homogeneizar, aunque se pretenda establecer un mínimo común.

También es confusa la Decisión Marco porque remite a genocidios (o crímenes de guerra) reconocidos por los tribunales internacionales o nacionales, dejando a los Estados que opten entre ellos. Lo que podría derivar en el supuesto

99 Tpiy, Chambre I, Le Procureur c/J.-P. Akayesu, jugement du 2 septembre 1998, http://www. un.org/icty/index-f.html

100 Tribunal mixto, cuya creación ha sido confiada a la Secretaría General del Consejo de Seguridad de Naciones Unidas, por la resolución 1315, de 14 de agosto de 2000.

101 Tribunal mixto, creado por acuerdo entre las Naciones Unidas y el Líbano. Resolución 1757, adoptada por el Consejo de Seguridad de Naciones Unidas el 30 de mayo de 2007. 
absurdo de que un Estado, pudiera excluir la penalización de la justificación del genocidio nazi y persiguiera otros supuestos. Ello contradeciría el espíritu de la norma, expuesto en su exposición de motivos.

En cuanto a los tribunales, éstos juzgan a personas concretas por hechos cometidos personalmente. No juzgan a la historia en abstracto, ni a un colectivo en su conjunto. La jurisprudencia es concreta y la finalidad del modo de operar de los tribunales es declarar la culpabilidad o no de determinadas personas, de los acusados, a la luz de las pruebas que les son aportadas por las partes o por el Ministerio Fiscal y las que recaben de oficio. Su fallo se centra en esos datos concretos y no es extrapolable a la actuación de todo un país o una población o de un Estado. En esto hay que ser prudentes ${ }^{102}$. Indudablemente el método histórico es muy distinto. La interpretación histórica está siempre abierta a la aparición de nuevos datos, mientras que las sentencias una vez firmes ya no pueden ser revisadas. Todo ello no es un obstáculo para el hecho de que determinados hechos históricos se den como probados, ya lo hemos señalado, pero la imputabilidad penal exige la condena de personas concretas que deben de cumplir un castigo también concreto y previsto previamente en la ley. De ahí que a la hora de establecer nuevos delitos, como el que estamos estudiando, se debe de ser muy cautos en la prueba de la responsabilidad penal de sus autores; la difusión de ideas o doctrinas con intención racista. Se les castiga por justificarlas, pero ellos no han cometido el genocidio, ni han colaborado. Muchos de ellos ni siquiera habían nacido cuando se dieron esos acontecimientos. De ahí, que en los códigos penales de los países que contemplan este delito la pena de quien participe en un genocidio y quien lo justifique en la actualidad difiere enormemente en los años de cárcel previstos. Además se debería exigir la prueba de la intención racista.

Y entramos aquí en otro tema conflictivo. Se ha criticado el Protocolo del Consejo de Europa porque, así como en el preámbulo y en la Informe explicativo del mismo (véase n. ${ }^{\circ} 39$ ) se hace una referencia explícita a la intención racista y xenófoba y a las ideas nazis, en el artículo 6, en su párrafo 1 , no se exige que la tipificación del delito responda explícitamente a la intención racista. Se deja abierta esa opción a los Estados en el segundo parágrafo del artículo 6. Varios de ellos que han ratificado el Protocolo han realizado declaraciones formales en las que han incluido la necesidad de la intención racista ${ }^{103}$. Conforme a las críticas, que comparto en este punto, no tiene mucho sentido que un Protocolo que

${ }^{102}$ Lagrou, P. (2006). «Sanctionner pénalement les négationnistes?», Politique, n. ${ }^{\circ} 47$, décembre, pp. 16-17, así como Dubuisson, F. o.c., p. 171., señalan que la verdad judicial y la verdad histórica responden a lógicas muy distintas.

103 Lista de declaraciones y reservas formuladas al Tratado n. ${ }^{\circ} 189$, http://conventions.coe.int. 
acompaña a una Convención sobre ciberdelincuencia, relativa a la penalización de actos de naturaleza racista y xenófoba no haga una referencia explícita a la intención racista o la voluntad de incitación al odio racial y a la violencia, dejando abierto en el art. 6.1 que se penalice el elemento material de la negación sin que exista el elemento subjetivo.

Con independencia de que, en la práctica existente hasta ahora, los tribunales nacionales suelan exigir la existencia de este elemento subjetivo, teniendo en cuenta también las circunstancias concretas del caso, la necesidad del dolo especial debería quedar recogido en la descripción del tipo penal ${ }^{104}$.

Otro de los problemas que señalan Schabas, Chrostakis y Bannelier, entre otros, se refiere a la posibilidad cubierta por el derecho a la libertad de expresión de criticar por parte de historiadores y juristas (expertos) incluso la calificación jurídica de sentencias firmes de tribunales internacionales ${ }^{105}$. Concretamente, sigue siendo un tema controvertido la consideración como genocidio por parte de la Corte Penal Internacional para la ex Yugoslavia y del Tribunal Internacional de Justicia de la matanza de 7000 hombres musulmanes en Srebrenica por los militares serbios. En este caso, no se discute que fuera un crimen contra la humanidad y un crimen de guerra, sino si la intención era la de exterminar a todos los musulmanes bosnios ${ }^{106}$.

\section{EL REQUISITO DE INTENCIÓN RACISTA Y DE PUBLICIDAD EN LA RECOMENDACIÓN N. ${ }^{\circ} 7$ DE LA ECRI}

La ECRI es una Comisión creada por el Consejo de Europa para combatir el racismo y la discriminación racial en Europa desde la perspectiva de la protección de los derechos humanos contemplados en el Convenio Europeo. Como señala

104 Cfr., Alastuey, C. (2013), «La reforma de los delitos de provocación al odio y justificación del genocidio en el Proyecto de Ley de 2013: consideraciones críticas», Diario La Ley, op.c., passim.

105 Véase la opinión del jurista, W. A., Schabas, W. A. (2001), «Was Genocide Commited in Bosnia and Herzegovina? First Judgments of the International Criminal Tribunal For the Former Yugoslavia», Fordham International, L. J., vol 25, p. 46. Disponible en: http://ir.lawnet. fordham.edu/ilj/vol25/iss $1 / 2$

Chrostakis, T. y Bannelier, K. (2007), «Qu'est ce qu'un génocide et quand un État estil responsable pour ce crime? Analyse de l'ârret rendu par la CIJ dans l'affaire Bosnie c. Serbie-etMontenegro», 26 février, R.. B. D. I., 2007.

106 Idem. Véase también la opinión del historiador STEINBERG, M. (2006). «Notre responsabilité», Politique, n. ${ }^{\circ}$ 47, décembre, p. 31. (Citado por F. Buisson, op. c., p. 172, nota 89). 
Martín Sánchez: «La Comisión Europea contra el racismo y la intolerancia (ECRI), en su Recomendación General n. ${ }^{\circ}$ 7, de 13 de diciembre de 2002, sobre la legislación nacional para combatir el racismo y la discriminación racial, solicitó a los Estados miembros del Consejo de Europa la adopción de medidas legales de tipo penal para combatir diversas expresiones racistas. Entre ellas, están comprendidas la incitación pública a la violencia, al odio o a la discriminación, a los insultos públicos y a la difamación, o a las amenazas contra una persona o un grupo a causa de su raza, color, lengua, religión, nacionalidad u origen nacional o étnico. Igualmente, esta Recomendación General manifestó que la expresión pública, con una finalidad racista, de una ideología racista o la negación pública con la misma finalidad de crímenes de genocidio, o contra la humanidad, o de guerra, también deberían ser sancionadas penalmente» ${ }^{107}$.

Si bien la Recomendación sugiere incluir como delito no sólo el negacionismo de genocidio, sino también los crímenes contra la humanidad o de guerra, en los tres casos se exige que esa expresión sea pública y, lo que es también crucial, se penaliza cuando exista necesariamente una motivación o intención racista. Ambas cosas se reflejan en el artículo 18. «d) la expresión en público, con un objetivo racista, de una ideología que reivindique la superioridad o que desprecie o denigre a una categoría de personas por motivos de raza, color, idioma, religión, nacionalidad, u origen nacional o étnico. e) la negación, banalización, justificación o aprobación en público con un objetivo racista, de delitos de genocidio, crímenes contra la humanidad o crímenes de guerra».

En este sentido, la redacción de la Recomendación n. ${ }^{\circ} 7$ de la ECRI, si bien no es un texto normativo, está mejor formulada que la Decisión Marco que venimos de analizar líneas más arriba. En suma, se precisa intención racista y además la negación, banalización, y justificación tienen que ser públicas para ser delictivas.

En la definición de conceptos que acompaña a esta Recomendación se señala que el párrafo e) del artículo 18 se refiere a los crímenes de genocidio, crímenes contra la humanidad y crímenes de guerra. El primero de ellos según se define en el artículo II de la Convención para la prevención y la represión del crimen de genocidio de la ONU y en el artículo 6 del Estatuto del Tribunal Penal internacional. Los segundos y terceros deben ser entendidos también tal y como se definen en los artículos 7 y 8 del Estatuto del Tribunal que acabamos de citar ${ }^{108}$.

107 MarTín SÁNCHEZ, Isidoro. (2012), «El discurso del odio en el ámbito del Consejo de Europa», Revista General de Derecho Canónico y Derecho Eclesiástico del Estado, 28, pp. 1-33. Aquí p. 5.

108 ECRI, Recommandation de politique générale n. ${ }^{\circ} 7$ de l’ECRI sur la législation nationales pour lutter contre le racisme et la discrimination raciales, adoptée le 13 décembre 2002, Strasbourg, Secrétariat de l’ECRI, Direction générale des droits de l’homme_DG II, Conseil de l’Europe, 17 de febrero de 2003, párrafo 41 sobre el párrafo 18 de la Recomendación. 
De hecho la primera jurisprudencia de condenas de este tipo en Alemania y Austria está relacionada con neonazis que querían restaurar este partido, pero está causada por defender una ideología nacionalsocialista y sus ideas racistas, no sólo por el hecho de reinstaurar un partido neonazi ${ }^{109}$. Por otro lado, una de las finalidades de la penalización de estas conductas es la de proteger la veracidad de lo ocurrido y evitar que se repita en la actualidad.

\section{LA DEFINICIÓN DE NEGACIONISMO COMO UNA FORMA DE DISCURSO DEL ODIO EN LA RECOMENDACIÓN N. ${ }^{\circ} 15$ DE LA ECRI}

En la reciente Recomendación de la Comisión Europea contra el racismo y la intolerancia, n. ${ }^{\circ} 15$, on combating Hate Speech, de 8 de diciembre de 2015, se define el discurso del odio como «the advocacy, promotion or incitement, in any form, of the denigration, hatred or vilification of a person or group of persons, as well as any harassment, insult, negative setereotyping, stigmatization or threat in respect of such a person or group of persons and the justification of all the preceding types of expression, on the ground of «race», colour, descent, national or ethnic origin, age, disability, language, religión or belief, sex, gender, gender identity, sexual orientation and other personal characteristics or status». Esta definición nos proporciona los elementos que hacen de una conducta expresiva un delito de odio. Es decir debe haber promoción o incitación con animo de denigrar y odiar a una persona o grupo de personas, o acoso o insulto con la intención de estigmatizarla, por razón de su raza, color, ascendencia, nacional o de origen étnico, edad, minusvalía, lengua, religión o creencia, sexo, género, identidad de género, orientación sexual y otras características o estatus. La ECRI especifica que considera que todos los seres humanos pertenecen a la misma especie y que rechaza las teorías basadas en la existencia de diferentes razas. Sin embargo, en esta Recomendación se utiliza el término «raza» con el fin de asegurar que estas personas que son percibidas general y erróneamente como pertenecientes a otra raza no sean excluidas de la protección proporcionada en esta Recomendación. La razón para criminalizar en el derecho internacional ciertas formas de discurso del odio

109 Grimm, Dieter, «The Holocaust Denial Decision of the Federal onstitutional Court of Germany», en I. Hare y J. Weinstein, Extreme Speech and Demcocracy, o.c., p. 558. Lipstadt, Deborah (1994), Denying the Holocaust - The Growing Assault on Truth and Memory, Penguin Books Limited, Londres, p. 74. El libro fue primeramente publicado en América en 1993, por Free Press, una division de Simon and Schuster. Fue republicado en Reino Unido por 1994 por Plume, una division de Penguin. 
fue la de proteger a miembros de grupos vulnerables, que podían ser de un modo desproporcionado objeto de persecuciones.

Analizando el marco jurídico que proporciona esta Recomendación n. ${ }^{\circ} 15$ de la ECRI, en conexión con todas las demás Recomendaciones, que busca encuadrar algunas interpretaciones basadas en el Convenio, en la jurisprudencia del TEDH y en las normas internacionales que ya hemos citado, se podrían extraer las siguientes pautas de actuación para formular los tipos penales.

Por un lado el bien jurídico protegido sería la igual dignidad de cada persona humana, en conjunción con otros derechos como la libertad de expresión y de opinión. Se recuerda que Europa tiene una especial obligación derivada de su historia de memoria, vigilancia de luchar contra el ascenso del racismo, la discriminación racial, discriminación basada en el género, el sexismo, la homofobia, transfobia, xenofobia, antisemitismo, islamofobia, antigitanismo y antitolerancia.

Esta recomendación trata de ir a la raíz de las discriminaciones raciales y luchar contra ellas de un modo holístico con medidas de educación en derechos humanos y de fomento del diálogo intercultural, especialmente emprendiendo acciones positivas para evitar las discriminaciones raciales y removiendo barreras que dificultan la comprensión entre personas de diferentes culturas. Por otro lado, hay una abanico amplio de medidas que comienzan por los códigos de autorregulación de la prensa, código éticos de conducta, también en las asociaciones deportivas y de los usuarios de internet. En estos últimos casos se insiste en que las regulaciones deben ser respetuosas con la libertad de expresión. Hay que fomentar los mecanismos de aplicación de las normas existentes, y en este ámbito regular procedimientos de recepción de quejas. Entre los medios jurídicos, deben tomarse medidas, a poder ser administrativas y civiles, con compensaciones económicas sanciones administrativas cuando existan responsabilidades administrativas, usando también este tipo de medidas contra las organizaciones. El derecho penal se considera el último instrumento a utilizar, cuando no haya otras medidas de naturaleza menos restrictiva. Su imposición se considera apropiada sólo en circunstancias muy limitadas, debido al riesgo potencial que plantean de violar el derecho de libertad de expresión.

En este contexto de actuación penal, se distingue entre el discurso del odio con sus diferentes formas delictivas y la negación del genocidio como un delito encuadrado dentro de los anteriores, pero con un tipo penal específico. El hecho lesivo que se quiere prevenir es la discriminación racial o la lesión de la dignidad de la persona. El Convenio de Derechos Humanos utiliza como límite el daño a la reputación de los demás. La Recomendación no habla de lesionar la «reputación», pero sí denigrar, estigmatizar e insultar que se podrían entender como una lesión de la reputación. 
Para ello se utilizan varios conceptos que conviene precisar. En cuanto a lo que se castiga es la provocación o incitación, en cualquier forma de la denigración, odio o vilipendio de una persona o de un grupo de personas, así como el acoso, insulto, estereotipar, estigmatizar o amenazar a esa persona o ese grupo de personas y justificar ese tipo de manifestaciones, por discriminación basada en la raza, el color, el origen nacional o étnico, la edad, discapacidad, lengua, religión o creencia, sexo, género, identidad de género u otras características o estatus. Criterios casi todos ellos contemplados en la Declaración Universal de Naciones Unidas, en el Convenio Europeo de Derechos Humanos, o en las directivas de la UE, a las que se añade género e identidad de género.

Líneas después al concretar en qué consiste la incitación, se precisa que se trata de incitar (o razonablemente que tenga el efecto de incitar a otros) a cometer actos de violencia, intimidación, hostilidad y discriminación contra aquellos que son objeto del mismo y se debe asegurar que es una forma seria de discurso.

Interpretando lo expresado en el texto, cabe concluir que el titular de la dignidad son las personas concretas individualmente o en grupo, pero en cuanto que cada uno de ellos posee una dignidad. No se contempla un derecho colectivo o una titularidad colectiva, aunque las demandas puedan ser accionadas colectivamente. En este sentido entendería que se otorga tutela a un daño que se pueda probar de vejación o humillación de uno varios individuos que son lesionados ${ }^{110}$. La acción penal contra conductas raciales tiene como objetivo proteger a los individuos y a los grupos, pero no a la creencias, a las ideologías o las religiones. Por eso las formas de expresión crítica de ideas están protegidas por el derecho de libertad de expresión, también las que ofendan, choquen o inquieten.

En cuanto al ilícito penal no se deriva de una mera conducta, sino que debe causar actos de violencia, intimidación, hostilidad o discriminación. Resulta importante destacar que en el momento en que se hablan de actos ya no aparece la palabra odio (aunque aparezca la de hostilidad que es bastante abstracta). A mi juicio, no se utiliza aquí la palabra odio porque el sentimiento de odio no se puede cuantificar, ni medir penalmente. Lo que se miden son sus efectos. Por otro lado la incitación es a «realizar actos concretos». En ningún momento se usa la palabra «clima hostil o clima de odio». El discurso debe buscar incitar, luego se requiere dolo, intención racista. Por otro lado, este tipo de expresiones debe hacerse a través de medios públicos, lo que incluye determinadas formas electrónicas de comunicación. Aunque la definición de discurso del odio no se

${ }^{110}$ La Recomendación no habla de tutelar sentimientos subjetivos colectivos, pero indudablemente es un equilibrio difícil, como señala Teruel, G., «La libertad de expresión...», o.c, p. 18. 
restringe a las expresiones usadas en público, la existencia de un contexto publico es un requisito esencial cuando se recomienda que las sanciones penales sean impuestas en ciertos usos del discurso del odio cuando esto interfiere con la libertad de expresión ${ }^{111}$. De manera que la conductas expresivas privadas de discriminación racial pueden tratarse con otros medios jurídicos, como la vía civil o las sanciones administrativas etc, pero no sería apropiado crear tipos penales.

Por ejemplo, en el uso de medios escritos debe medirse si existe un acceso del público en general. Este es un elemento esencial para saber si se trata de un delito racial. Por tanto, los tres elementos comunes a los delitos de odio son que sean públicos y persigan discriminar racialmente a una persona, con intención de denigrarle, siendo también un criterio que la persona que emite ese discurso o conducta expresiva refleje o promueva la injustificada asunción de que se considera superior a la persona o grupo que denigra o insulta. Es evidente que este hecho se debe de probar.

Siguiendo con mi propia interpretación, se deriva que la recomendación anima a penalizar palabras que impliquen una peligrosidad potencial o hipotética y/o una peligrosidad concreta ${ }^{112}$. Por tanto, no se está recomendando a los Estados adelantar la barrera punitiva. Para medir si hay riesgo de que se produzcan esos actos hay que tener en cuenta las circunstancias específicas en el que se produce el discurso. Concretamente si existen tensiones en la sociedad, la capacidad de la persona de usar ese discurso para influir en otros (es decir, si ocupa un papel relevante por ser político, un líder religioso o líder de una comunidad), la naturaleza y dureza del lenguaje usado (si es provocativo y directo, si implica estereotipos negativos, estigmatización, capaces de incitar a los actos mencionados), si se realizan reiteradamente, si hay posibilidad de contra-argumentar o no, especialmente en el curso de un debate, el medio usado y la naturaleza de la audiencia ${ }^{113}$. En mi opinión, el juez debe hacer una valoración del contexto social y se debe probar la conexión casual entre el discurso emitido y sus efectos, así como probar el resultado lesivo, el riesgo y la peligrosidad.

Se caracteriza como una forma especial de discurso del odio los supuestos en los que dicho discurso adquiera la forma de una negación pública, trivialización, justificación o condonación del crímenes de genocidio, crímenes contra la humanidad o crímenes de guerra, cuya existencia haya sido reconocida por los tribu-

\footnotetext{
111 Ídem., n. ${ }^{\circ} 20$.

112 Admito que la cuestión sobre el peligro abstracto quizá no queda muy explicitada y requiera un mayor análisis.

113 Ídem., n. ${ }^{\circ} 16$.
} 
nales, y la glorificación de las personas condenadas por haber cometido tales crímenes. Aplicando las características indicadas en el párrafo anterior a esta justificación de crímenes de genocidio, para calificarlas como delitos de odio, deben responder a la intencionalidad de denigrar o estigmatizar a personas o grupos actuales por razón de su raza, religión nacionalidad o por su origen étnico etc. La criminalización de este discurso está relacionado con su objetivo, que es herir a individuos o grupos. De lo que se deriva que debe haber incitación o provocación de denigrar a personas o grupos, que se exige dolo con intención racista y realizarse de modo público. El contenido del injusto es que se genere un peligro cierto de actos ilícitos contra las personas o grupos. Junto a ello, la libertad de expresión como crítica a determinadas creencias, ideologías o religiones estará protegida por el derecho a la libertad de expresión contemplado en el artículo 10 de la Convención Europea de Derechos Humanos.

Otras dos características que deben confluir para dar lugar a delito de discurso de odio es que ese discurso refleje o promueva una asunción injustificada de que quien lo emite se considera superior a una persona o a un grupo que son objeto de esa crítica. Además ese discurso debe tener como intención el incitar o esperar razonablemente el efecto de incitar a otros a cometer actos de violencia, intimidación, hostilidad o discriminación contra quienes va dirigido el discurso crítico, ya que de este modo esto constituye una forma especialmente seria de discurso de odio. Es decir, el elemento de incitación implica que exista una clara intención de incitar a cometer actos de esos tipos, o un riesgo inminente de que esos actos ocurran a consecuencia de ese particular discurso de odio utilizado $^{114}$. No se especifica si la incitación es directa o indirecta.

En este marco jurídico, se explicita un delito con tipo especial que tendría lugar en la forma de negación pública, trivialización, justificación o condonación de los crímenes de genocidio, crímenes contra la humanidad o crímenes de guerra (retomado la recomendación n. ${ }^{\circ} 7$ de la ECRI). Se inaugura dos conceptos que no figuraban en los tratados internacionales que hemos visto, a saber los de condonación y el de glorificación (que podríamos considerar equivalente al de enaltecimiento) de las personas que han cometido esos crímenes. El memorándum proporciona una definición de los términos empleados. Concretamente resulta útil aclarar que el término "glorificación» se entiende cómo la celebración o alabanza de alguien que haya cometido genocidio. Así como se define «condonación», como excusar, perdonar o pasar por alto una particular conducta ${ }^{115}$. Esos genocidios deben de haber sido reconocidos por los tribunales, sin especificar aquí de

${ }^{114}$ Cfr, Explanatory Memorandum, n. ${ }^{\circ} 14$.

115 Explanatory Memorandum, n. ${ }^{\circ}$ 7.m y $7 . e$ respectivamente. 
qué tipo de tribunales se trata (siguiendo el Convenio de Cibercriminalidad que admite los naciones e internacionales). Todas esas conductas descritas para ser delictivas deben haber sido realizadas con un fin racista y/o discriminatoria.

En la otra cara de la moneda se sitúa la defensa de la libertad de expresión y el peligro de que la penalización de determinadas conductas como delitos de odio puedan ser usadas por los gobiernos para suprimir cualquier libertad de crítica en la sociedad o silenciar a las minorías o de crítica política o de crítica de las creencias. A su vez la libertad de expresión protege discursos que pueden ofender, chocar o herir.

\section{EL CRITERIO SENTADO POR EL TEDH. EL DEBATE LEGÍTIMO DE IDEAS Y LOS HECHOS HISTÓRICOS CLARAMENTE ESTABLECIDOS}

En el marco del Consejo de Europa el Convenio europeo de Derechos Humanos defiende en su artículo 10, el derecho de libertad de expresión. Este derecho no es un derecho absoluto y admite que el Estado ponga límites al ejercicio del mismo si son necesarios en una sociedad democrática según el artículo 10§2. Sin embargo es doctrina sentada por el TEDH como intérprete del Convenio, que las limitaciones impuestas por los Estados deben ser las mínimas. El adjetivo «necesario», implica una necesidad social imperiosa. En esto los Estados contratantes poseen un cierto margen de apreciación, pero deben de utilizar este poder con buena fe, con cuidado y de forma razonable. El TEDH para conocer si el Estado ha actuado dentro de lo previsto en el Convenio y en caso de restricción de derechos, si lo haya hecho de forma necesaria en una sociedad democrática debe examinar los derechos en juego, utilizando las técnicas de la ponderación y del principio de proporcionalidad. Concretamente para examinar si la injerencia en el derecho de libertad de expresión está justificada debe tener en cuenta el conjunto de los hechos, las circunstancias del caso y examinar si esa injerencia o restricción en el ejercicio del derecho a la libertad de expresión ha sido proporcionada al bien legítimo perseguido y si los motivos invocados por las autoridades nacionales para justificarlo parecen pertinentes y suficientes ${ }^{116}$.

Hay que situar el art. 10 sobre libertad de expresión como un derecho precioso en el Convenio teniendo en cuenta que esté se hizo en el periodo de después de la II Guerra Mundial, en 1950, y para evitar los totalitarismos tanto de derechas como de izquierdas. En ese sentido, la libertad de expresión es la base de las democracias europeas, pero no es en si misma un fin, sino un medio para el

${ }^{116}$ Cfr., TEDH, Perinçek c. Suiza, n. ${ }^{\circ}$ 196.iii. 
fomento de la dignidad humana. Quizá sea este uno de los puntos clave que diferencia el lugar que ocupa este derecho en Europa frente a Estados Unidos, que lo constituye como un fin en si mismo, lo que se refleja en la primera enmienda de la Constitución americana ${ }^{117}$. De ahí que a mi juicio no es muy útil, ni loable intentar introducir en Europa los criterios de la jurisprudencia estadounidense $^{118}$, como ya he señalado en la introducción de este artículo.

Dado que ningún derecho es absoluto, el art. 10.2 del Convenio Europeo prevé unos límites, cuyo control justifica la injerencia del Estado en ese derecho, subordinados a condiciones precisas: deben estar previstos en la ley, perseguir un bien legítimo y ser proporcionales al fin perseguido ${ }^{119}$.

En relación con el debate legítimo de ideas, el Tribunal Europeo de Derechos Humanos ha sentado un criterio, según el cual la negación de hechos históricos claramente establecidos no estará protegido por el derecho a la libertad de expresión, contemplado en el artículo 10 del Convenio Europeo de Derechos Humanos. La otra cara de la moneda es que también el Tribunal Europeo de Derechos Humanos ha acuñado la frase de que la libertad de expresión del art. 10 del Convenio puede proteger ideas que hieran, choquen o inquieten ${ }^{120}$. Pero, como contraste, también el art. 10.2 establece unos límites en el ejercicio de la libertad de expresión cuando exista una voluntad de promover una ideología racista o xenófoba o de denigrar a las víctimas ${ }^{121}$. El dilema se sitúa en la pregunta sobre si es legítimo prohibir la expresión de ciertas ideas en una sociedad que se basa en el postulado de que la verdad nace de la libre confrontación de opiniones,

117 Señala las diferencias y algunas semejanzas Bustos GisBert, Rafael (2015), «Libertad de expresión y discurso negacionista», en Miguel Revenga (Dir.), Libertad de expresión y discursos del odio, Universidad de Alcalá, Servicio de Publicaciones, pp. 123-147.

${ }_{118}$ Un estudio profundo sobre las diferencias lo ofrece AlCACER Guirao, Rafael (2013),»Víctimas y disidentes. El "discurso del odio" en EEUU y Europa», Revista Española de Derecho Constitucional, n. ${ }^{\circ} 97$, pp. 308-441.

119 Tulkens, T.o. c., p. 429.

120 TEDH, Handyside c. Reino Unido, 7 de diciembre de 1976, parágrafo 49. HaARSCHER. Guy (2007), «La répression du négationnisme est-elle philosophiquement justifiable?», Communication au Colloque International Négationnisme (s)-GenocideEDenial, Bruxelles, Université Libre de Bruxelles.

121 Art. 10.2: «El ejercicio de estas libertades que implican deberes y derechos puede estar sometido a ciertas formalidades, condiciones, restricciones y sanciones previstas por la ley, que constituyan medidas necesarias, en una sociedad democrática, para la seguridad nacional, la integración del territorio o la seguridad pública, para la defensa del orden y la prevención del crimen, para la protección de la salud o de la moral, para la protección de la reputación o de los derechos de los demás». 
incluso indignantes ${ }^{122}$. Trataremos ahora brevemente el primer aspecto, relacionado con los hechos históricos claramente establecidos, dejando para el siguiente epígrafe el análisis concreto de sentencias paradigmáticas del TEDH en relación con el negacionismo.

La pregunta que se suscita es quién determina cuáles son esos hechos históricos claramente establecidos. En realidad, aquí se dan dos elementos distintos: uno, la existencia de un hecho, aportado por el conocimiento común o por las ciencias académicas, como la historia. Un segundo hecho, es el uso que los tribunales realizan de esos datos históricos. Para ello se deben dar dos premisas: la primera es que ese hecho sea una verdad histórica. En principio se parte de que haya sido establecida por los historiadores, en su mayoría, como hecho probado. Pero eso no es suficiente para calificar un hecho histórico como genocidio, sino que requiere un segundo paso, a saber: que esos hechos hayan sido calificados como genocidios por tribunales internacionales. Algunos historiadores académicos, como Roth, critican que en este caso la verdad histórica sea la establecida por un tribunal, es decir por una verdad jurídica ${ }^{123}$.

Atendiendo al modo como el TEDH ha utilizado este principio o criterio no parece que esa critica sea pertinente, aunque hay que reconocer como afirman Alcácer Guirao ${ }^{124}$ y Bilbao Ubillo ${ }^{125}$ que el TEDH no siempre ha tratado de modo similar situaciones semejantes. En realidad, hay una larga jurisprudencia por la que, en múltiples ocasiones, los tribunales han aceptado como indudables hechos que cualquier persona normal, sin excesiva cultura conoce y de los que nadie duda. Son datos objetivos, hechos innegables que son conocidos por el ciudadano medio en una determinada época. No es que esos hechos se conviertan en verdaderos o en ciertos a causa de que los reconozca un juez, sino más bien el razonamiento es el contrario. El juez los reconoce porque le vienen dados por la ciencia histórica o el conocimiento común. Cosa diferente es que el tribunal los use para culpabilizar a quienes, como es el caso del genocidio, los hayan cometido en su momento o a quienes en la actualidad quieran restablecer ideas que

122 Wachsmann. P. (2001), «Liberté d'expression et négationnisme», Revue trimestrielle $d u$ Droits de l'homme, numéro spécial «Le droit face à la montée du racisme et de la xénophobie», p. 587.

123 Roth, R. (2004), «Le juge et l'histoire», en J., Boisson de Chazournes, F., Quéguiner y S. Villalpando (dir.), Crime de l'Histoire er réparations: les réponses du droit et de la justice, Bruxelles, Bruylant, Editions de 1'Université de Bruxelles, pp. 4-5.

${ }_{124}$ Alcacer Guirao, R., «Libertad de expresión, negación del holocausto y defensa...», o.c., pp. 322-326.

${ }_{125}$ Bilbao Ubillos, Juan María (2008), «La negación del holocausto en la jurisprudencia del Tribunal Europeo de Derechos Humanos: la endeble justificación de tipos penales contrarios a la libertad de expresión». Revista de derecho político, n. ${ }^{\circ}$ 71-72, pp. 17-56. 
inciten a volverlos a cometer o introduzcan ideas o doctrinas racistas que vuelven a poner las bases de regímenes genocidas, basados en doctrinas sobre la superioridad de una raza (en el caso del nazismo, la raza aria) sobre otras razas.

Concretamente, uno de los puntos incontrovertidos en el TEDH ha sido aceptar el genocidio establecido en el Tribunal Militar internacional de 1945, por el acuerdo de Londres de 8 de agosto de $1948^{126}$. La referencia a este Tribunal es constante, tanto en este Protocolo Facultativo, como en la Decisión Marco de la UE, como en el Convenio de Naciones Unidas, como en la mayoría de las legislaciones nacionales que han introducido el delito de negación o justificación del genocidio $^{127}$. Por ahora, este es el único núcleo duro que figura en todas las legislaciones, tanto internacionales como nacionales.

\section{EL TRIBUNAL EUROPEO DE DERECHOS HUMANOS, LA LIBERTAD DE EXPRESIÓN Y SUS LÍMITES}

La Jurisprudencia del TEDH se basa en demandas de ciudadanos contra sus Estados, alegando que su libertad de expresión no ha sido respetada, es decir por violación del art. 10 de la Convención. Las sentencias del TEDH son suficientemente elocuentes para ofrecernos un marco conforme al cual el negacionismo del Holocausto, el odio racial y el racismo no pueden ser protegidos bajo el art. 10 . Todas esas reclamaciones se han declarado inadmisibles ${ }^{128}$. Nos fijaremos estrictamente en la jurisprudencia relacionada con la negación del Holocausto, a raíz de casos de personas que defienden las ideas nazis.

El TEDH ha utilizado principalmente dos vías: la vía de los límites de la protección de los derechos garantizados, que está prevista en el art. 10.2 del Convenio, en relación con el derecho a la libertad de expresión: la vía de exclusión de la protección del Convenio, prevista en el artículo 17, que versa sobre la prohibición del abuso de derecho. Además también ha desarrollado una aproximación de naturaleza mixta en la que ha combinado los artículos 10 y 17, aunque el asunto se ha sometido al examen habitual del art. 10. 2, sin un examen de

126 Estatuto del Tribunal de Nuremberg y su jurisprudencia.

127 Bélgica, Alemania, Francia. Ver PECH, Laurent (2011), «The Law of Holocaust Denial in Europe. Toward a (qualified) EU-wide Criminal Prohibition», en Genocide Denial and the Law, o.c, pp. 190-206, sobre Alemania y Francia.

128 Véase PECH, Laurent. (2011). «The Law of Holocaust Denial in Europe. Toward a (qualified) EU-wide Criminal Prohibition», o.c, pp. 213-222. Lasson, Keneth (2011), «Defending Truth: Holocaust Denial in the Twenty-First Century», en Genocide Denial and the Law, o.c, pp. 144-147. Sobre la legislación de Canadá, Inglaterra, Francia, Suecia y Estados Unidos. 
fondo, pero dentro del artículo 10 (Kühnen c. Alemania, n. ${ }^{\circ}$ 12194/86, decisión de la Comisión de 12 de mayo de 1988, DR 56).

Esas vías no se excluyen mutuamente ya que en otros asuntos, aunque el TEDH consideraba que hubiera debido ser inadmisible porque lo demandado era incompatible con la democracia y los derechos humanos, y no se podría invocar la protección del artículo 10, a pesar de ello se examina si la injerencia en la libertad de expresión ha estado o no justificada (Molnar c. Rumania, n. . 16637/06, de 23 de octubre de 2012).

Un tercer grupo de asuntos son aquellos en los que aunque el Tribunal podría haber invocado el artículo 17 y declarar la inadmisibilidad, no obstante ha preferido entrar al fondo, por ejemplo en Leroy c. Francia (n. ${ }^{\circ}$ 36109/03, de 2 de octubre de 2008). El demandante en este asunto fue condenado en Francia por apología del terrorismo por un dibujo que había hecho inspirado en los atentados terroristas contra el World Trade Center de Nueva York en 2001 y que publicó dos días después. Demandó a su gobierno por violación del artículo 10. El TEDH entró al fondo, distinguiéndolo de los otros casos en los que había aplicado el artículo 17 por considerar que en estos últimos la intención odiosa e injuriosa del interesado era inequívoca (todos casos relacionados con el nazismo). En este caso examina el artículo 10.2, realiza la ponderación de los derechos en juego y concluye que la injerencia del Estado ha sido justificada y la sanción aplicada era proporcionada.

En sucesos más recientes, relacionados con discursos racistas e islamófobos ha entrado también al fondo, examinado si las restricciones de la libertad de expresión eran necesarias (Soulas c. Francia n. ${ }^{\circ}$ 15948/03, de 8 de julio de 2008 y Féret c. Bélgica (n. ${ }^{\circ} 15615 / 07$, de 17 de julio de 2009). En estos asuntos, una vez justificada la restricción del derecho de libertad de expresión, la corte ha manifestado que no hubiera sido viable un uso del artículo 17, para declarar la inadmisibilidad (lo cual es una evidencia, ya que de hecho había admitido la demanda).

Estos cuatro diversos modos de utilizar los artículos 17 y 10 no obedecen a una evolución cronológica, ya que siguen siendo usados en la actualidad dependiendo del caso, si bien últimamente el TEDH es menos proclive a utilizar directamente el artículo 17 para inadmitir el caso. Adelantando desde ahora nuestra opinión, considero que sería deseable que el TEDH usara esa cláusula de modo muy excepcional, siendo necesario que en la mayoría de los asuntos entrara al fondo de los mismos examinando, conforme a los métodos de argumentación jurídica y de proporcionalidad, la necesidad de restringir o limitar en los casos concretos el derecho de libertad de expresión. 
Ya desde los años 60, la Comisión de derechos humanos ha rechazado demandas por considerar que lo solicitado era contrario al Convenio y afirmando que los Estados habían limitado los derechos sin violar el art. 10. Entre otras, se podrían citar dada su importancia, las dos siguientes decisiones:

Decisión X. C. Austria, de 13 de diciembre de 1963. El demandante había sido condenado en Austria por sus actividades neonazis en base a la ley que prohibía el partido Nacional Socialista (N. S. D. A. P.). La Comisión considera la demanda no admisible porque la ley austriaca cumple con los tres requisitos citados anteriormente, que legitiman restringir en este caso la libertad de expresión que incluya ideas racistas ${ }^{129}$.

La decisión X. c República federal de Alemania, de 16 de julio de 1982 [n. ${ }^{\circ}$ 9235/81, Décisions et rapports (DR) 29, p. 194], está relacionada también directamente con el neonazismo. La Comisión declara inadmisible el recurso, considerando que es legítimo para el Estado prohibir la propagación de una publicación que califica como mentira el hecho histórico del asesinato de millones de judíos por el régimen nazi, lo cual es una medida necesaria en una sociedad democrática para la protección de la libertad de los demás ${ }^{130}$.

En estas decisiones no se entra a calibrar si cabe o no el ejercicio del derecho de libertad de expresión del art. 10 y se analiza tan sólo si los Estados han aplicado legítimamente los límites a la libertad de expresión previstos en el art. 10.2. En muchas ocasiones, como hemos señalado antes, no se utilizó directamente el artículo 17, sino que se aplicaba el 10.2, teniendo el 17 de fondo como un criterio interpretativo. La inadmisibilidad de la demanda se basaba en el art.10.2. Así fue en los siguientes casos:

Kühnen c. La República Federal Alemana, decisión de 12 de mayo de 1988. El demandante ocupaba una posición alta en una organización que intentaba reconstruir el partido nacionalsocialista. Se le había condenado en Alemania por haber publicado tractos que podían resucitar los sentimientos antisemitas. La Comisión examina el asunto a la luz del art. 10.2. Para ponderar la necesidad de la medida llevada a cabo por el Estado alemán se reenvía al artículo 17 para

129 Commission européenne des Droits de l'homme, rêquete n. ${ }^{\circ} 1747 / 62$, décision $H . W . P$ y X. C. Austria, de 13 de diciembre de 1963 (n. ${ }^{\circ} 12774 / 82$, DR 62).

${ }^{130}$ Commission européenne des Droits de l'homme, rêquete n. ${ }^{\circ} 92351 / 81$, décision $X$. C. República federal de Alemania, de 16 de julio de 1982 (n. ${ }^{\circ}$ 9235/81). Es también significativa la Comisión Europea de Derechos Humanos (no publicada), décision Felderer c. Suecia, de 1 de julio de 1985. El demandante había difundido un dibujo de un hombre desnudo, llamado Zyklon B. Goldman (nombre del producto que se usó en las cámaras de gas) en el que su introducción en una cámara de gas era presentado como factores de belleza y de salud. Posterior Ochensberger c. Austria, de 2 de septiembre de 1994, n. ${ }^{\circ} 21318 / 93$, no publicada). 
analizar si la injerencia es proporcional. Se concluye afirmativamente y se rechaza entonces la demanda por falta manifiesta de fundamento ${ }^{131}$. La Decisión Walendy c. Alemania, de 11 de enero de 1995 [n. 21128/92, DR 83-B] trata del secuestro de un periódico que niega la realidad del Holocausto ${ }^{132}$. La Decisión Remer c. Alemania, de 6 de septiembre de 1995 [n. 25096/94, DR 82-B] también examina un publicación que pone en entredicho la existencia del Holocausto $^{133}$. De modo similar la Decisión Honsik c. Austria, de 18 de octubre de 1995 [n. ${ }^{\circ}$ 25062/94, DR 82-B] se centra en la condenación por negar en una publicación la realidad del Holocausto ${ }^{134}$. En la Decisión Partido Nacionaldemocrático de Alemania (N. P. D.) Beziksverband München-Oberbayern c. Alemania, de 29 de noviembre de 1995 [n. $25992 / 94$, DR 84-B], una autoridad local había prohibido que durante una de las reuniones de ese partido se hiciera alguna declaración negando la persecución de los judíos por los nazis ${ }^{135}$. La Decisión Rebhandl c. Austria, de 16 de enero de 1996 n. ${ }^{\circ}$ 24398/94, no publicada en la Compilación], afronta la condena por difusión de una revista negando la realidad de las cámaras de gas en los campos de exterminio ${ }^{136}$. En la Decisión Marais c. Francia, de 24 de junio de 1996 [n. $31159 / 95$, DR 86-A], de modo parecido, se examina una condena de una revista por haber publicado un artículo poniendo en tela de juicio la existencia de cámaras de gas en el campo de concentración de Struthof ${ }^{137}$. La Decisión D. I. c. Alemania, de 26 de junio de 1996 (n. ${ }^{\circ} 26551 / 95$, no publicada en la Compilación), trata igualmente de la condena de una publicación que negaba la existencia de las cámaras de gas ${ }^{138}$. Por último, en esta serie, en la Decisión Nachtmann c. Alemania, de 9 de septiembre de 1998 (n. ${ }^{\circ} 36773 / 97$, no publicada en la Compilación), se condena al demandante por haber publica-

131 Commission européenne des Droits de l’homme, Décision Kühnen c. La República Federal Alemana, de 12 de mayo de 1988.

132 Commission européenne des Droits de l’homme, Décision Walendy c. Alemania, de 11 de enero de 1995 .

133 Commission européenne des Droits de l'homme, Décision Remer c. Alemania, de 6 de septiembre de 1995.

${ }^{134}$ Commission européenne des Droits de l'homme, Décision Honsik c. Austria, de 18 de octubre de 1995.

135 Commission européenne des Droits de l'homme, Décision Partido Nacionaldemocrático de Alemania (N. P. D.) Beziksverband Múnchen-Oberbayern c. Alemania, de 29 de noviembre de 1995.

136 Commission européenne des Droits de l'homme, Décision Rebhandl c. Austria, de 16 de enero de 1996.

137 Commission européenne des Droits de l'homme, Décision Marais c. Francia, de 24 de junio de 1996.

138 Commission européenne des Droits de 1'homme, Décision D. I. c Alemania, de 26 de junio de 1996. 
do un artículo en el que se decía que el número de víctimas del genocidio perpetrado por los nazis se había sobreestimado ${ }^{139}$.

La argumentación de fondo en estas decisiones fue unir estas conductas a ataques contra la comunidad judía intrínsecamente unidos a la ideología nazi, antítesis de la democracia y los derechos humanos. También apreció una incitación al odio racial, al antisemitismo y a la xenofobia, concluyendo que las condenas penales pronunciadas contra los autores eran necesarias en una sociedad democrática.

\section{EL ARTÍCULO 17 DEL CONVENIO Y LA PROHIBICIÓN DE ABUSO DE DERECHO. EL PELIGRO POR LA INAPLICACIÓN DEL PRINCIPIO DE PROPORCIONALIDAD}

En una segunda época, que comienza cronológicamente en el año 1998, la Comisión comienza a hacer un uso directo del artículo 17 aplicando el criterio de abuso de Derecho para declarar la inadmisibilidad de varias demandas, todas ellas relacionadas directamente con el tema que nos ocupa ${ }^{140}$. Según la jueza Tulkens, en esa segunda fase el TEDH adopta «una versión fuerte de la disposición» ${ }^{141}$.

El artículo 17 del Convenio de Derechos Humanos prevé que: «Ninguna de las disposiciones del presente Convenio pueden ser interpretadas como implicando que un Estado, un grupo o un individuo, tenga derecho a dedicarse a una actividad o llevar a cabo un acto contra la destrucción de los derechos o libertades reconocidos en el presente Convenio o a limitaciones más amplias de los derechos y libertades que los previstos por el mencionado Convenio» ${ }^{142}$. Se trata de una propia prevención prevista ya en el Convenio para negar la protección de los derechos a quienes quieren utilizar las garantías de la Convención para atacar los valores de la misma. Según relata la jueza Tulkens, el TEDH pasó de un uso

139 Commission européenne des Droits de l’homme, Décision Nachtmann c. Alemania, de 9 de septiembre de 1998.

140 Levinet, Michel (2004), «La fermeté bienvenue de la Cour européenne des droits de l’homme face au négationnisme. OBs. S/ La decisión du 24 juin 2003, Garaudy c. France», Revue trimestrielle des Droits de l'homme, p 656 (pp. 653-662). Disponible en: http://www.rtdh.eu/ pdf/2004653.pdf

141 Tulkens, F.o.c., p. 435.

142 Oetheimer, M. (2007), «La cour europeénne des droits de l'homme face au discours de haine», Revue trimestrielle des Droits de lTHomme, n. ${ }^{\circ}$ 69, pp. 69-70. KEANE, David. (2007). «Attacking hate speech under Article 17 of the European Convention on Human Rights», Netherlands Quaterly of Human Rights, pp, 641-664. 
poco frecuente del artículo 17 frente al negacionismo, o un empleo «blando», a un uso frecuente ${ }^{143}$.

Nos centraremos a continuación en el uso del artículo 17 sólo en relación con los casos de negacionismo. Tempranamente el Tribunal utilizó este concepto, en la sentencia Lawless $\left(n^{\circ} 3\right)$ c. Irlanda ${ }^{144}$. Esta disposición se aplica tanto al Estado, como a los individuos o a los grupos de individuos. La razón de ser del artículo 17 es proteger la propia democracia contra su propio suicidio, debido a que la historia europea ha demostrado que la existencia de constituciones democráticas no es suficiente para impedir la llegada al poder de regímenes totalitarios como el nazismo o el comunismo ${ }^{145}$.

En el Informe de la Comisión en el asunto Glasenapp c. Alemania, de 11 de mayo de 1984 se afirmó: «Cuando un gobierno trata fundamentalmente de proteger la preeminencia del derecho y de la democracia, el Convenio reconoce él mismo en su artículo 17 la primacía de este tipo de objetivo que va más allá de la protección de los derechos particulares garantizados además por el Convenio» ${ }^{146}$.

Cuando se utiliza el artículo 17 en estos casos, lo que la Comisión o el TEDH está afirmando es que estas demandas son inadmitidas porque el recurrente ha realizado un discurso negacionista que está prohibido en su legislación nacional sobre hechos históricos claramente establecidos, y por tanto no tiene derecho a ser protegido por el art. 10 del Convenio, por lo que el TEDH ni siquiera entra a examinar si la medida llevada a cabo por el Estado está justificada dentro de los límites permitidos en el art. 10.2.

Hoy en día esa falta de examen sería considerada inapropiada. En la protección de los derechos fundamentales es imprescindible realizar la tarea de ponderación entre los derechos protegidos y examinar el principio de proporcionalidad, opinión compartida por autores como Alcácer Aguado ${ }^{147}$ y Teruel Lozano ${ }^{148}$ entre otros. Pero curiosamente hoy todavía algunos magistrados del TEDH justifican el uso del artículo 17, como por ejemplo el juez Silvis en su voto particular en la sentencia Perinçek c. Suiza en la que afirma que «considero que, en

143 Tulkens, F. o. c., p. 433.

${ }^{144} \mathrm{CEDH}$, Lawless c. Irlanda, n. ${ }^{\circ} 3$, de 1 de julio de 1961, parágrafo 7.

145 Commission Européenne des Droits de l'homme, Décision Partie Communiste de l'Allemagne c. Allemagne, de 20 de julio de 1957.

146 Commission Européenne des Droits de l’homme, Décision Glasenapp c. Alemania, de 11 de mayo de 1984, párrafo 110.

147 Alcácer Aguado, R., «Libertad de expresión...», o.c., p. 322.

148 Teruel Lozano, G. (2015), «La libertad de expresión frente a los delitos de negacionismo y de provocación al odio y a la violencia: sombras sin luces en la reforma del Código Penal», Indret, pp. 2-51. 
el asunto de autos, la intención de insultar la memoria de las víctimas del genocidio armenio era manifiesta y que, en esto, la conducta del demandante estaba dirigida contra los valores que sostiene la Convención. No obstante como la posición adoptada por la Gran Sala en el plano procedimental era que el trámite de la violación del artículo 10 había sido declarado admisible por la sala, la aplicación del artículo 17 no podía conducir por tanto a la inadmisibilidad de esta demanda. En estas condiciones, hubiera preferido un enfoque consistente principalmente en librarse de una análisis del fondo bajo la perspectiva del artículo 17 antes de entrar en el terreno del artículo $10 \gg^{149}$.

Por otro lado, el hecho de que el TEDH considere que el Convenio permite a los Estados limitar actividades que transgreden las conductas amparadas por el art. 10 no significa que el art. 17 obligue a los Estados a tomar este tipo de medidas. Del mismo modo que, como luego analizaremos, del hecho de que el TEDH haya considerado conforme al Convenio legislaciones que penalicen la difusión de ideas genocidas no se puede inferir que el TEDH sostenga que los Estados tengan obligación de introducir estas conductas como delitos en sus códigos penales ${ }^{150}$.

En la sentencia del TEDH Lebideux e Isorni c. Francia, de 23 de septiembre de 1998, el TEDH indica, en un obiter dictum, que «la negación o la revisión de ciertos hechos históricos, claramente establecidos - tal y como es el Holocaustoestará sustraído por el art. 17 a la protección del art. 10» ${ }^{151}$.

En esta actitud adoptada por el TEDH con la cual se evita entrar al fondo del asunto y por tanto se omiten los argumentos en los que se fundamentaría la denegación de amparo teniendo en cuenta las circunstancias de cada caso, ha influido quizá la dificultad especial de prueba que se da en los casos de delito de negacionismo del genocidio. Este problema es una característica frecuente en todos los países a la hora de condenar a los negacionistas. Es a su vez un rasgo común a todos los negacionistas su persistencia y tenacidad en acudir a todas las instancias judiciales, así como el estar siempre defendidos por avezados especialistas, ir siempre de víctimas, negar su intención racista frente a sus declaraciones más clamorosas etc, confundiendo a los propios jueces, hasta el punto que la mayoría de las sentencias de tribunales nacionales europeos, aunque sean condenatorias, tienen siempre votos particulares.

149 TEDH, Perinçek c. Suiza, voto particular del juez Silvis, punto 9.

${ }^{150}$ Como el voto mayoritario argumenta en Perinçek c. Suiza.

151 TEDH, Lehideux e Isorni c. France, de 23 de septiembre de 1998, párrafo 47. En la sentencia TEDH Jersild c. Dinamarca, de 23 de septiembre de 1994, parece que el artículo 17 es utilizado implícitamente. 
En mi opinión, todo ello no se basa en la dificultad teórico-doctrinal de conciliar el derecho de libertad de expresión con el derecho de la igual dignidad de todas las personas, sino en la manera torticera en la que los negacionistas son capaces de usar los propios formalismos jurídicos para denunciar defectos formales en sus procesos, aunque el tema sustantivo de su intención racista sea evidente ${ }^{152}$, al margen de los defectos en el enunciado jurídico de los propios códigos penales que desgraciadamente juegan a su favor ${ }^{153}$

La Decisión del TEDH en el asunto Witzsch c. Alemania, de 20 de abril de 1999 (n. ${ }^{\circ} 41448 / 98$ ), recibirá bastantes críticas por el hecho de que se declara la inadmisibilidad de la demanda basándose en el art. 17 por incompatibilidad ratione materiae con los derechos protegidos por el Convenio ${ }^{154}$. En mi opinión, un tema poco claro en este caso es que el Estado alemán condena al demandante

${ }^{152}$ El caso español Pedro Varela Geiss es un buen exponente de lo que intento reflejar. Tanto es así que ha logrado que suscite una cuestión de insconstitucionalidad ante el Tribunal Constitucional español. STC 235/2007. Cuestión de inconstitucionalidad 5152-2000. Planteada por la Sección Tercera de la Audiencia Provincial de Barcelona respecto al artículo 607.2 del Código Penal. Además ganó una demanda contra España ante el TEDH (Asunto Varela Geiss c. España, CEDH, Sección tercera, Demanda n. ${ }^{\circ}$ 61005/09, 5 de marzo de 2013), viéndose el Gobierno de España obligado a pagarle 8.000 euros por daño moral y 5.000 por las costas. La sentencia del TEDH es ajustada a derecho porque Varela logró que efectivamente uno de los tribunales españoles cometiera un error procesal formal. A pesar de ello, y a pesar de la cuestión de inconstitucionalidad, que en teoría le favorecía, fue condenado primeramente a siete meses de cárcel, que tuvo que cumplir. Finalmente, el Ministerio Fiscal no cejó y la Audiencia Provincial de Barcelona en una nueva denuncia le condenó a una pena de dos años y nueve meses, que también ha cumplido. Pero la doctrina mayoritaria del Tribunal Constitucional ha causado confusión entre los jueces, y el resultado es que el Tribunal Supremo, Sala segunda de lo Penal, Sentencia n. ${ }^{\circ}$ 259/ 2011, de 12 de abril de 2011, por mayoría aplastante, en el caso de la librería Kalki, ha absuelto a los implicados, después de una sentencia que se extiende con más de 250 folios, con una descripción de hechos que no parecen dejar duda a la subsunción de los mismos en los actuales tipos existentes de delito de racismo (art.510 CP) y justificación de genocidio (art. 702.2 CP). Aunque para algunos penalistas como Alastuey en esta última sentencia se hace un uso correcto del tipo penal.

153 Esto es también innegable. Por ejemplo en Varela Geiss y Perinçek.

${ }^{154}$ Decisión Witzsch c. Alemania, CEDH, de 20 de abril de 1999. Una crítica extensa, que comparto, a la actuación del TEDH en los dos asuntos Witzsch 1 y Witzsch 2 en Alcácer Guirao, R. «Libertad de Expresión...», pp. 320-323. En la primera demanda del Witzsch ante el TEDH el 20 de abril de 1999 sí que utilizó al artículo 10 como criterio adicional, desestimado el amparo considerando proporcional la condena de tres meses de cárcel impuestas por los tribunales penales alemanes. Sin embargo, en la segunda sentencia del 13 de diciembre de 2005, a raíz de nuevas condenas que recibe por otras cartas dirigidas a particulares, se inadmite la demanda en base al artículo 17, evitando entrar al fondo del asunto y realizar una ponderación. Independientemente de que el contenido de la carta sí que niega la intención de Hitler de asesinar a los judíos y afirma que en Alemania no se había asesinado a un solo judío, es una carta privada, elemento que el TEDH no tuvo en cuenta. 
por negar la existencia del Holocausto en una carta privada que el afectado envía a un especialista en historia y este último entrega a la policía. En este supuesto se debería haber entrado al fondo del asunto, porque, a mi juicio, una carta privada carece de la publicidad y difusión de ideas que suele requerirse en el delito de negacionismo. El Tribunal nacional y el TEDH tendrían que haber tenido en cuenta ese hecho. En cuanto al fondo, el TEDH no aceptó el argumento del demandante de que él no negaba el Holocausto, ni la existencia de las cámaras de gas, sino que negaba que Hitler lo hubiera planificado, iniciado y organizado $^{155}$. El TEDH consideró que el protagonismo de Hitler y del Nacionalsocialismo en el Holocausto era un hecho históricamente establecido, criterio sentado en la ya mencionada sentencia Lebideux e Isorni c. Francia. En definitiva, que no puede dudarse de que esos hechos sucedieron.

La Decisión Garaudy c. Francia, de 24 de junio de 2003 (n. ${ }^{\circ}$ 65831/01, CEDH, 2003-IX), es una de las más significativas ${ }^{156}$. Para cuando el caso llegó ante el TEDH, Garaudy tenía ya 90 años. Nacido en 1913, Garaudy fue filósofo, escritor, político, marxista, luego cristiano y finalmente convertido al Islam. En diciembre de 1995 publicó un libro titulado, «los mitos fundadores de la política israelita», en él que dedicaba dos capítulos al genocidio judío, titulados respectivamente «los mitos de la justicia de Nuremberg» y «el mito del Holocausto»:

La obra, que es la causa de estas condenas del demandante, analiza de modo detallado varios sucesos históricos relativos a la Segunda Guerra Mundial, tales como la persecución de los judíos por el régimen nazi, el Holocausto, el proceso de Nuremberg. Apoyándose en numerosas citas y referencias, el demandante pone en tela de juicio la realidad, la amplitud y la gravedad de estos hechos históricos que no son objeto por tanto de debates entre los historiadores, sino por el contrario están claramente establecidos. Aparece, como lo han mostrado las jurisdicciones nacionales tras un estudio detenido del método y de los datos profundizados, que lejos de limitarse a una crítica política o ideológica del sionismo y de las actuaciones del Estado de Israel, o incluso de proceder a una

155 Una crítica extensa, que comparto, a la actuación del TEDH en los dos asuntos Witzsch 1 y Witzsch 2 en Alcácer Guirao, R., «Libertad de Expresión...», pp. 320-323. En la primera demanda del Witzsch ante el TEDH el 20 de abril de 1999 sí que utilizó al artículo 10 como criterio adicional, desestimado el amparo considerando proporcional la condena de tres meses de cárcel impuestas por los tribunales penales alemanes. Sin embargo, en la segunda sentencia del 13 de diciembre de 2005, a raíz de nuevas condenas que recibe por otras cartas dirigidas a particulares, se inadmite la demanda en base al artículo 17, evitando entrar al fondo del asunto y realizar una ponderación.

156 TEDH, Roger Garaudy c. Francia, n. ${ }^{\circ}$ 6531/01, 2003-IX, Sección cuarta, decisión sobre la admisibilidad, 24 de junio de 2003. Entre los jueces se encontraban entre otros Bratza, Costa, Casadevall, Borrego-Borrego. 
exposición objetiva de tesis negacionistas y de reclamar solamente como él lo pretende «un debate público e histórico» sobre el hecho histórico de la existencia de las cámaras de gas, el demandante ha hecho suyas esas tesis y procede de hecho a una puesta en duda sistemática de los crímenes contra la humanidad cometidos por el nazismo contra la comunidad judía.

De manera que, según el TEDH, no hay ninguna duda que negar la realidad de hechos históricos claramente establecidos como el Holocausto, como lo hace el demandante en su obra, no revela de ningún modo un trabajo de investigación histórica similar a una búsqueda de la verdad. El objetivo y el fin de una tal investigación son totalmente diferentes, ya que se trata de hecho de rehabilitar el régimen nacionalsocialista y, por la vía de la consecuencia, acusar de falsificación de la historia a las víctimas mismas. Así, la negación de crímenes contra la humanidad aparece como una de las formas más agudas de falsificación de difamación racial contra los judíos y de incitación al odio en relación con ellos. La negación o la revisión de hechos históricos de este tipo ponen en duda los valores que fundan la lucha contra el racismo y el antisemitismo y son de tal naturaleza que perturban el orden público. En cuanto afectan a los derechos de otros, tales actos son incompatibles con la democracia y los derechos humanos y sus autores van en contra incontestablemente de los objetivos del tipo de los prohibidos en el art. 17 del Convenio.

El Tribunal considera que la mayor parte del contenido y del tono general de la obra del demandante y su fin, tiene un marcado carácter negacionista y son contrarios a los valores fundamentales del Convenio, tal y como están expresados en el Preámbulo, a saber la justicia y la paz. La Corte considera que el demandante intenta desviar el artículo 10 del Convenio de su vocación utilizando el derecho a la libertad de expresión con fines contrarios a la literalidad y al espíritu del Convenio. Tales fines, si fueran admitidos, contribuirían a la destrucción de los derechos y libertades garantizadas por el Convenio.

En consecuencia, el Tribunal estima que en virtud de las disposiciones del artículo 17 del Convenio, el demandante no puede prevalerse de las disposiciones del artículo 10 del Convenio en lo que concierne a los elementos relevantes de la negación de crímenes contra la humanidad. Por tanto, esta parte de la demanda es incompatible ratione materiae con las disposiciones del Convenio en el sentido del artículo $35 \S 3$ y debe ser rechazado en aplicación del artículo 35.4.

Le corresponde a continuación al Tribunal examinar los aspectos del libro del demandante criticando el Estado de Israel y la comunidad judía y que ha sido el origen principal de las condenas del demandante por difamación racial y provocación al odio racial. El Tribunal considera que estas condenas penales, pronunciadas en relación con el demandante, pueden ser consideradas, el Gobierno 
no lo niega, como injerencias de las autoridades públicas en el ejercicio de la libertad de expresión reconocidas en el artículo 10. 1 del Convenio. Las partes están de acuerdo en considerar que las injerencias estaban previstas por la ley, a saber en los artículos 24, línea 6 y 32 línea 2 de la Ley de 29 de julio de 1881, modificada por la ley de 13 de julio de 1990.

El Tribunal estima que estas injerencias persiguen al menos dos de los fines legítimos previstos por el Convenio: «la defensa del orden y la prevención del crimen» y «la protección de la reputación y de los derechos de los demás». En efecto, contrariamente al demandante que pretende que las disposiciones pertinentes de la ley de 1881 tienen como objetivo instaurar una censura abusiva y que no constituyen medidas necesarias en una sociedad democrática, el Tribunal afirma que estas disposiciones persiguen preservar la paz en el seno de la población francesa (ver decisión de Pierre Maris ${ }^{157}$ ).

El Tribunal ha probado tener serias dudas sobre el punto de saber si, por las mismas razones que ha mencionado anteriormente (ver el párrafo i. Supra), y teniendo en cuenta el tono global negacionista de la obra, la expresión de tales opiniones podría estar protegida por las disposiciones del artículo 10 del Convenio. En efecto, si una crítica de la política del Estado de Israel, o de otro Estado, estaría protegida sin duda por este artículo, el Tribunal ha constatado que el propósito del demandante no se limita a una tal crítica y tienen en realidad un objetivo racista probado.

De todos modos, el Tribunal no considera necesario en este caso pronunciarse sobre este punto, porque de todas maneras esta parte de la demanda es inadmisible. En efecto, teniendo en cuenta el tenor de los escritos del demandante, los motivos invocados por las jurisdicciones nacionales para la condena por difamación racial y provocación al odio racial eran pertinentes y suficientes, y las injerencias «necesarias en una sociedad democrática» en el sentido del artículo 10.2 del Convenio. De ello se sigue que esta parte de la demanda debe ser rechazada como manifiestamente mal fundada, en aplicación del artículo 35 $\S \S 3$ y 4 del Convenio.

Este modo de examen ha sido continuado en sentencias más recientes como por ejemplo Norwood c. Reino Unido, n. ${ }^{\circ}$ 23131/CEDH 2004-XI y Kasymakhurov y Saybatalov c. Rusia, n. ${ }^{\circ}$ s 26261/05 y 26377/07, de 14 de marzo de 2013, Gollnisch c. Francia, n. ${ }^{\circ} 48135 / 08$, de 7 de junio de 2011. En esta última, el TEDH responde a las críticas recibidas por usar en ocasiones el artículo 17, como sinónimo de ausencia de un apropiado análisis jurídico. En este caso, el tribunal analiza en detalle las opiniones políticas de los demandantes que pertenecían al

157 CEDH, Marais c. Francia, de 24 de junio de 1996. 
grupo fundamentalista Hizb ut-Tahrir con el fin de motivar la razón por la que los demandantes no tenían derecho a la protección de los artículos 9, 10 y 11 del Convenio. En Schimanek, Witzsch (n. ${ }^{\circ} 1$ ) y Gollnish, el Tribunal realiza un argumento similar al de la antigua Comisión justificando la necesidad de la injerencia del derecho de libertad de expresión en una sociedad democrática, sin embargo en Garaudy y Witzsch (n. ${ }^{\circ}$ 2) sólo utiliza el artículo 17.

Tulkens opina que el Tribunal no tratará necesariamente otros genocidios o crímenes contra la humanidad de la misma manera que ha tratado el Holocausto, dadas las características contextuales del mismo ${ }^{158}$. Una opinión fundada, que comparto y apoya la tesis que se defiende en este artículo. Ciertamente el TEDH ha tratado con dureza todo lo referente al Holocausto, mientras que en otros casos de negación de otros hechos históricos, como el genocidio armenio, discursos contra el Islam ${ }^{159}$, o la publicación de un calendario antisemita en Lituania ${ }^{160}$ ha entrado a ponderar los derechos en conflicto.

En resumen y siguiendo con la línea defendida en este artículo, aun pudiendo ser aceptable que el Tribunal haya utilizado en el pasado el art. 17 en estos casos claros de negacionismo, sería más adecuado que no lo use paralelamente en nuevas situaciones de justificación del holocausto o de discurso del odio frente a otros genocidios o la negación de otros hechos históricos. Es importante que cuando la limitación de la libertad de expresión esté justificada, el TEDH realice una argumentación ponderada sobre la necesidad de la medida y la proporcionalidad de la restricción del derecho a la libertad de expresión.

Los criterios emanados de la jurisprudencia del TEDH para limitar la libertad de expresión y ver si entra dentro del campo protegido por el artículo 10, son que la injerencia esté prevista por la ley y que persiga un fin legítimo de los previstos en el art. 10.2, y que sea necesaria en una sociedad democrática para alcanzar sus fines. Además para controlar el margen de apreciación de los Estados, el tribunal debe examinar el fin u objetivo perseguido por el demandante y si supone una intención racista, el contenido de la expresión en causa, y el con-

158 Tulkens, F. o. c., p. 439. De la misma opinión es Mcgonagle, T. (2007), «Normes juridiques internationales et européennes relatives à la lutte contre les expressions racistes», en Commission européenne contre le racisme et l'intolérance. Lutter contre le racisme tout en respectant la liberté d'expression, Éditions du Conseil de l'Europe, Strasbourg, p. 58.

159 TEDH, Soulas y otros c. Francia, de 10 de junio de 2008. Sobre la publicación de un libro en Francia denunciando que el Islam quería hacerse con el poder político de Europa y criticando a los africanos y magrebíes residentes en Francia.

160 TEDH, Balsyté-Lideikiene c. Lituania, de 4 de noviembre de 2008. A raíz de un calendario que imputa a los judíos y polacos la comisión de genocidio contra los lituanos. 
texto en el que se emite esa expresión teniendo en cuenta todas las circunstancias concretas del caso.

En relación a los tres puntos se requiere un examen atento: primero, en cuanto al fin debe de analizar si se trata de propaganda de ideas y opiniones racistas que configuran un discurso de odio (tratan de estigmatizar a personas o atizar la violencia y el odio) o si se trata de informar al público sobre una cuestión de interés general: segundo, en cuanto al contenido el Tribunal ha de entrar a ver si los contenidos son de interés político o de interés general, o si son de carácter religioso. También debe juzgar si lo que se expresa son contenidos factuales o si se hace un valor sobre los mismos (en este caso deben de basarse en hechos, aunque sean valorativos), cuestión decisiva para calificar si estamos ante la justificación de genocidio: en cuanto al contexto, se ha de considerar la función o el lugar que ocupa en la sociedad quien realiza un discurso o difunde unas ideas por escrito, es decir si esa persona es un hombre político, si es un periodista o persona que trabaja en los medios de comunicación, o si es un funcionario. Además en relación con el contexto se ha de valorar el impacto potencial que tiene esa conducta expresiva, a saber en qué medio de difusión se ha dado a conocer, si es en prensa escrita, en un medio de difusión público, o si es una expresión artística. Todo ello puede afectar en distinta medida a otras libertades, como la libertad de opinión, la libertad de prensa, la libertad artística etc. Por otro lado, hay que valorar el contexto geográfico y social en el que esas ideas se han difundido $^{161}$.

A ello se añade, que a continuación hay que utilizar las técnicas de la ponderación y el principio de proporcionalidad típicas del derecho, como la naturaleza y gravedad de la injerencia, es decir su necesidad y su idoneidad, estudiar si no habría otros medios alternativos y menos gravosos que lesionen en menor medida los derechos del demandante y los otros derechos en juego ${ }^{162}$. Por tanto,

161 Véase, Weber, Anne, o.c, pp. 30-46. Sobre los pasos necesarios para aplicar el principio de proporcionalidad en el Tedh, Elósegui, M. (2016), «El principio de proporcionalidad de Alexy y los acomodamientos razonables en el caso del TEDH Eweida y otros c. Reino Unido/ Das Verhältnismässigen anpassungen in der Entscheidung des Europäischen Gerichtshofs für Menschenrechte (EGMR) im Fall Eweida und Andere gegen das Vereignigte Köngsreich», en ELósEGUI, María (Coordinadora), Los principios y la interpretación judicial de los Derechos Fundamentales. Homenaje a Robert Alexy en su 70 aniversario, Zaragoza, Fundación Giménez Abad, Alexander von Humboldt Stiftung y Marcial Pons, 2016, pp. 157-186 y pp. 333-365.

162 Véase Van Drooghenbroeck, Sébastien, La proportionnalité dans le droit de la convention européenne des droits de l'homme. Prendre l'idée simple au serieux. Bruxelles, Bruylant, 2001, pp. 213-475. Bernal Pulido, C. (2007), El principio de proporcionalidad y los derechos fundamentales, Madrid, CePC. Clerico, Laura (2009), El principio de proporcionalidad en el derecho constitucional, Buenos Aires, Eudeba. 
el tribunal se enfrenta a la tarea de la calificación de los hechos dentro de la norma estatal y a la luz del Convenio Europeo de Derechos Humanos, también debe emitir un juicio sobre la intención del demandante, y valorar las circunstancias geográficas y las repercusiones negativas concretas de esos hechos en las minorías o en personas concretas, es decir si el discurso ha lesionado bienes jurídicos penales.

\section{LA PONDERACIÓN DEL TEDH EN EL CASO PERINÇEK C. SUIZA}

Como el presente artículo se centra en la justificación del genocidio judío como delito, servirá el análisis de la sentencia del TEDH Perinçek contra Suiza para reforzar los argumentos que hemos esgrimido precisamente porque en ella el TEDH realiza una argumentación dando todos los pasos de ponderación y del principio de proporcionalidad que nos parecen necesarios, como acabamos de indicar, para una correcta motivación de la sentencia. No por ello quedan superados los problemas de argumentación jurídica y la coherencia de los mismos. Este asunto versa sobre la cuestión controvertida de si la masacre cometida contra el pueblo armenio en 1915 se puede calificar o no como un genocidio. El propósito de este epígrafe no es el afrontar este problema, que excede del objetivo de este estudio, sino mostrar los criterios de análisis que en esta ocasión utiliza el TEDH, en la sentencia se recogen además toda la jurisprudencia anterior y los criterios sentados sobre el negacionismo, la negación de hechos históricos y las cuestiones de la negación o afirmación del genocidio armenio. Hasta ahora de modo intencionado entre la jurisprudencia que hemos citado no hemos recogido apenas la jurisprudencia relacionada con Turquía, por un lado porque no se han planteado en ese país cuestiones relacionadas con el holocausto judío y por otro porque la situación del contexto geográfico, político, cultural y religioso hace que los asuntos (frecuentes por otro lado) que llegan al TEDH y sus fallos sean poco transferibles a otros países del Consejo de Europa, especialmente a los que son también miembros de la UE.

Los hechos del caso versan sobre Dogu Perinçek, el demandante, líder del Partido Patriótico turco que vive alli1 ${ }^{163}$, que fue condenado en Suiza por las afirmaciones realizadas durante su asistencia a unas conferencias en 2005 en el país helvético, con ocasión del $82 .^{\circ}$ aniversario del Tratado de Lausana, que estableció oficialmente en 1923 las fronteras de la actual Turquía, y en otros dos

163 Ha sufrido penas de cárcel en Turquía por pertenecer al partido comunista y el TEDH ha condenado dos veces a ese país por violación de los derechos de Perinçek. 
actos. En dicho evento Perinçek culpó a los imperialistas de Occidente y a la Rusia zarista de provocar tensiones entre musulmanes y armenios a fin de debilitar el imperio Otomano y aseguró que las masacres no fueron un intento premeditado de cometer una limpieza étnica. El tribunal de distrito de Lausana le condenó y multó en el año 2007 por violar las leyes suizas contra el racismo porque calificó sus afirmaciones como discriminatorias. En el año 2001 y 2003 los cantones suizos de Ginebra y Vaud habían reconocido oficialmente la masacre armenia como genocidio y el parlamento suizo también lo reconoció en 2003. En realidad el artículo del Código penal suizo número 261 bis, al. 4, no menciona como delito el genocidio armenio, simplemente prohíbe negar o justificar el genocidio y crímenes contra la humanidad, sin concretar a qué genocidios se refiere. Fue la asociación Suiza-Armenia la que presentó una denuncia oficial contra Perinçek, argumentando que negar, menospreciar o justificar el genocidio viola la ley antirracismo suiza. Se le condena a una pena de 90 días de multa, a 100 francos suizos (62 euros) al día, a una multa de 3.000 francos suizos (1.859 euros) sustituible por 30 días de privación de libertad. El 12 de marzo de 2007 Perinçek apela la decisión del Tribunal de Lausana y el 12 de diciembre del mismo año el Tribunal Federal Suizo confirma la decisión de Tribunal de Lausana. Agotadas las instancias internas, Perinçek apela al TEDH. El Tribunal de primera estancia del TEDH ampara su demanda y falla que la condena de Perinçek viola su derecho a la libertad de expresión en virtud del artículo 10 del Convenio el 17 de diciembre de $2013^{164}$. Esa sentencia es apelada el 17 de marzo de 2014 ante la Gran Sala por Suiza a la que se suman Armenia, Turquía y Francia. El 15 de octubre de 2015 la Gran Sala confirma la decisión de que Suiza violó el derecho de Perinçek a su libertad de expresión.

Los argumentos del TEDH, en suma, se resumen en afirmar que las declaraciones de Perinçek no constituían una apología del odio o la intolerancia, que los tribunales suizos le habían «censurado por haber expresado simplemente una opinión divergente a las manifestadas en Suiza» y «que su condena había sido innecesaria para la protección de los derechos de la comunidad armenia». El TEDH no entra a examinar si el genocidio de los armenios es un hecho probado o no. Lo que se pregunta es si Perinçek ha hecho con buena fe tres veces estas afirmaciones de que el genocidio armenio no había existido, es decir si su motivación es o no racista. Perinçek admite el hecho de las deportaciones de miles de armenios de las fronteras rusas hacia las actuales Siria e Irak, pero discute el carácter genocida de estas deportaciones.

164 TEDH (primera instancia), Perinçek c. Suiza, 13 de diciembre de 2013. 
El gobierno suizo argumenta que el artículo 261 bis del Código Penal suizo penaliza la negación de genocidios reconocidos por un Tribunal Internacional, teniendo en cuenta la intención del legislador y los antecedentes de la elaboración de la misma por el Parlamento suizo. Sostiene que es cierto que la literalidad del artículo únicamente menciona «genocidio», y que no dice «genocidio reconocido por un Tribunal de Justicia Internacional». Por ello, para interpretar su sentido recurre al Boletín oficial del Consejo Nacional, donde el legislador se refirió explícitamente a la Convención Internacional para la represión del crimen de genocidio de 9 de diciembre de 1948 de la ONU, poniendo como ejemplo el genocidio de los kurdos y de los armenios (BOCN 1993, p. 1076). El Consejo Nacional suizo tomó como ejemplo el genocidio armenio a la hora de legislar el art. 261 bis del CP, aun desatendiendo al Consejo federal que consideraba que la cuestión debía ser tratada por los historiadores. La opinión pública helvética lo considera como tal, aunque no haya sido reconocido por ningún tribunal internacional.

Lo que muestra las dificultades que venimos subrayando sobre la redacción de las normas jurídicas. Por otro lado, el gobierno suizo admite que hay distintas interpretaciones entre historiadores sobre la masacre de los armenios. No todos lo consideran un genocidio, pero insisten en que está así calificado por una mayoría de historiadores. Lo cual confirma también a mi juicio que su valoración es todavía un hecho controvertido entre historiadores. Sin embargo la acusación pide que sea el TEDH quien tenga en cuenta ese hecho, basándose en esas opiniones mayoritarias, aunque no haya sido reconocido por un tribunal internacional. El demandante mantiene que no corresponde a un Tribunal hacer la historia. El TEDH considera igualmente que no le corresponde hacer de historiador.

Lo destacable en esta sentencia es que el TEDH realiza una ponderación de los derechos en conflicto siguiendo todos los pasos que deberían ser los habituales. Examina si el Estado ha utilizado su margen de apreciación de buena fe, y de un modo razonable: analiza si la injerencia en el derecho de libertad a la luz del conjunto de datos del caso concreto había sido proporcionada con el fin legítimo perseguido y si los motivos invocados por las autoridades nacionales para justificarlos son pertinentes y suficientes (n. $\left.{ }^{\circ} 196\right)$. El otro criterio sentado es que el margen de apreciación que se permite al Estado es mucho más restringido cuando el discurso es político o de temas de interés general (n. $\left.{ }^{\circ} 197\right)$.

Se recuerdan en la sentencia todos los precedentes elaborados por el TEDH. Muchos de ellos ya han sido expuestos anteriormente a lo largo de este artículo. Sólo queremos destacar que el Tribunal admite que un estereotipo negativo cara a un grupo étnico puede a partir de un cierto grado, actuar sobre el sentido de la identidad de este grupo así como a los sentimientos de estima de si mismo y 
de confianza en si de los miembros de este grupo, y que puede afectar a la vida privada de ese individuo o grupo (de la víctima) (Aksu c. Turquía (GC), n. ${ }^{\text {s }}$ 414904 y 41029/04, \$67, CEDH, 2012). También la reputación de un ascendiente puede atentar contra el derecho a la vida privada (Putistin c. Ucrania, n. ${ }^{\circ} 16882 / 03, \$ \$ 33$ y 36-41, 21 de noviembre de 2013).

Al Tribunal no le corresponde decir si la penalización de la negación del genocidio o de otros hechos históricos puede en principio estar justificada. El Tribunal examina los casos concretos teniendo en cuenta las circunstancias (n. ${ }^{\circ}$ 266). Debe ver si es necesario proteger los derechos de los otros con medidas penales, en este caso la dignidad de los armenios y de sus antepasados, en relación con la identidad construida sobre la idea de que la comunidad ha sido víctima de un genocidio (identidad étnica). Para realizar el ejercicio de ponderación debe tener en cuenta: el peso relativo a atribuir a cada uno de esos dos derechos en las circunstancias de este caso concreto: la necesidad de restringirlos, o de proteger, cada uno de ellos, y la proporcionalidad entre los medios empleados y el fin deseado. Para ello necesita analizar la naturaleza de la intención del demandante en el contexto, la medida en que su conducta ha herido los derechos de los armenios, la existencia o no de consenso entre los países parte del Convenio en cuanto a la necesidad de sancionar con medidas penales conductas de esta naturaleza, la existencia de reglas de derecho internacional en la materia, el razonamiento seguido por las jurisdicciones suizas para justificar la condena del demandante y la gravedad de la injerencia (n. ${ }^{\circ} 228$ ).

El Tribunal sigue uno a uno todos esos pasos en su argumentación. La Gran Sala entiende que la conducta del demandante era de orden político y que toca un tema de interés público. El Tribunal no ve en esa conducta una forma de incitación al odio o a la intolerancia, ni de desprecio a las víctimas. El demandante no ha tratado a los armenios como mentirosos, ni ha usado términos injuriosos contra ellos, ni ha buscado caricaturizarlos. Sus alegatos se dirigían contra el imperialismo. A continuación se examina si en las circunstancias concretas la conducta constituye una forma de incitación al odio o a la intolerancia contra los armenios. En la jurisprudencia referente al holocausto judío, el Tribunal entendía que existía ese propósito por razones históricas y del contexto. Pero el Tribunal piensa que no puede juzgar este caso del mismo modo, donde el demandante se expresa en Suiza sobre un tema acaecido en el imperio otomano hace cien años. No hay elementos para probar en este caso una intención racista y antidemocrática, tampoco genocida. Tampoco sus artículos de prensa demuestran que sea anti-armenio. El mismo Tribunal había amparado al demandante por el intento del gobierno turco de disolver un partido político que buscaba que la población kurda hiciera valer sus derechos políticos con medios democrá- 
$\operatorname{ticos}^{165}$. El demandante no ha justificado un genocidio, sino que ha negado un genocidio $^{166}$. En cualquier caso, como el genocidio armenio no está reconocido por tribunales internacionales, no entra a este tema, sino que afirma que la conducta de Perinçek no se puede interpretar como una llamada a la violencia, al odio o a la intolerancia. Hace suya la afirmación del TC español, la justificación de un genocidio no consiste en afirmar que un evento particular no constituye genocidio, sino en formular conductas expresivas haciendo un juicio de valor sobre un genocidio relativizando la gravedad o poniéndola en cuestión (n. ${ }^{\circ} 240$ ). La conducta es de interés público, luego la posibilidad del gobierno suizo de limitarla es menor.

El Tribunal siempre tiene en cuenta el contexto histórico del país miembro para juzgar o evaluar si hay o no una necesidad social imperiosa de recurrir a la injerencia en el ejercicio de un derecho garantizado por el Convenio. Especialmente en el caso del Holocausto, la penalización de su negación no se debe tanto a que sea un hecho histórico claramente establecido, sino al contexto histórico de los países en cuestión. Hasta ahora han sido Alemania, Austria y Bélgica (en el caso español sobre Varela Geiss no se examinó el asunto bajo el artículo 10). «La negación, incluso maquillada de investigación histórica imparcial, traduce invariablemente una ideología antidemocrática y antisemita. La negación del Holocausto es peligrosa por doble motivo, sobre todo en los Estados que han conocido los horrores nazis y por lo que se puede estimar que tienen una responsabilidad moral particular: distanciarse de las atrocidades de masa cometidas por ellos o con su complicidad, especialmente prohibiendo la negación» (n. ${ }^{\circ} 243$ ). En comparación, no hay ningún vínculo directo de Suiza con los sucesos de 1915 en el imperio otomano. La polémica es exterior a la vida política suiza, el demandante es extranjero y vive en otro país, al que ya ha vuelto. Además en el momento en que se hicieron esas declaraciones no había ningún clima en Suiza que fuera a generar graves fricciones entre los turcos y los armenios que viven en ese país, a diferencia de otros casos enjuiciados por el Tribunal referentes a Turquía, en años que reinaba una gran tensión entre ambas comunidades y con la policía, que se saldaron con muertes de una parte y de otra. De hecho en Suiza no ha habido ningún proceso penal entre ambas comunidades. La condena del tribunal suizo no había hecho ninguna referencia al contexto turco, sino

165 TEDH, Perinçek c. Turquía, n. ${ }^{\circ}$ 46669/99, 21 de junio 2005.

166 Aquí el TEDH se refieren a Varela Geiss c. España, n. ${ }^{\circ}$ 61005/09, 5 de marzo de 2013, y parece asumir la interpretación del TC español de que negar y justificar son dos cosas distintas, cuando en realidad el asunto examinado por el TEDH en la demanda de Varela Geiss presentada ante ese tribunal fue una cuestión de defecto procesal en las instancias penales españolas y violación del debido proceso. 
que se refiere al contexto nacional suizo. El Tribunal estima que esa medida de penalización no es proporcional, ni necesaria en una sociedad democrática como Suiza. Además el propio demandante tampoco ha querido suscitar ningún odio contra la comunidad armenia en Turquía. Se tiene en cuenta el hecho de que un periodista turco-armenio Hrant Dink fue asesinado en 2007 por ultranacionalistas turcos, siendo posible que su asesinato tuviera relación con sus opiniones vertidas sobre los sucesos de 1915, pero todo ello no guarda ninguna relación con las opiniones vertidas por Perinçek en Suiza. Examinando el factor temporal también se afirma que han transcurrido 100 años desde los sucesos de 1915. El tiempo transcurrido desde el tiempo que ha sucedido un evento histórico también ha de tenerse en cuenta, y no conviene aplicar a las polémicas históricas la misma severidad dependiendo de si son más recientes o no. En cuanto a los derechos de terceros, los comentarios del demandante no estaban dirigidos contra la comunidad armenia, sino que acusa a los imperialistas de haber atizado la violencia entre turcos y armenios. Tampoco su intención ha sido la de denegar la masacre y las deportaciones masivas de armenios, por lo que sus afirmaciones no tienen que tener consecuencias graves en la identidad de los armenios como grupos, lo que no impide que en otros casos juzgados por el Tribunal, con otras circunstancias y en un contexto específico, «conductas expresivas relacionadas con eventos históricos traumáticos hayan sido susceptibles de atentar contra la dignidad de los grupos afectados por esas conductas, si son particularmente virulentas y difundidas de forma que sea imposible ignorarlas... Los únicos casos en que la antigua Comisión y el Tribunal han admitido la existencia de esas circunstancias sin exigir pruebas específicas son las relacionadas con la negación del Holocausto» (n. ${ }^{\circ}$ 253). Se tiene en cuenta también el modo de difusión, si ha transcendido a muchas personas o no. Tampoco hay consenso entre los firmantes de la Convención existiendo diversas legislaciones, que ya hemos señalado. Tampoco los tratados internacionales obligan a penalizar la negación del genocidio en cuanto tal negación, tampoco lo exige la Convención para la prevención del genocidio de la ONU de 1948. Como hemos recogido en este artículo, el Tribunal hace una interpretación de la legislación vigente coincidente con lo que hemos expuesto. En resumen, el artículo $6 \$ 1$ del Protocolo adicional a la Convención sobre la cibercriminalidad se aplica a la negación si es por medio de un sistema informático de genocidios reconocidos como tales por una decisión final de un tribunal internacional competente: en el informe explicativo del protocolo se precisa que se trata de tribunales internacionales establecidos a partir de 1945 por los instrumentos internacionales pertinentes, tales como el TPIY (Tribunal Penal Internacional para la antigua Yugoslavia, el TPIR (Tribunal Penal Internacional para Ruanda) y la Corte Penal Internacional. Además, 
el segundo párrafo del artículo permite a los estados parte del protocolo reservarse el derecho de no aplicar en todo o en parte ese primer párrafo.

Como también ya hemos insistido, el TEDH recuerda que la ECRI es el único organismo que preconiza que se criminalice la negación del genocidio como infracción penal si es intencional: «la negación, la minimización grave, la justificación o la apología pública, con un fin racista, de crímenes de genocidio, crímenes contra la humanidad o crímenes de guerra» (Recomendación n. ${ }^{\circ} 7$ de la ECRI). En cuanto a la norma suiza por la que se le condena a Perinçek el Tribunal no parece compartir la explicación aportada por el gobierno suizo del significado de la norma y de que incluya la negación de unos hechos que no están declarados jurídicamente hasta ahora como genocidio, lo que en el fondo, como alega el demandante, él no podía prever que denegar esa calificación de genocidio a la masacre de armenios iba a constituir una infracción en el derecho suizo.

El Tribunal considera que la injerencia ha sido desproporcionada teniendo en cuenta la situación de la democracia suiza y que habría otros medios alternativos menos lesivas de su derecho como hubiera sido la vía del derecho civil. En esa circunstancia particular las autoridades suizas no han hecho un justo balance entre el derecho de Perinçek y el derecho de los armenios a la protección de su dignidad.

En conclusión, declara que ha habido violación del art. 10 del Convenio, una vez examinado que las declaraciones obedecían a una cuestión de interés público, que no estaban motivadas por una llamada al odio o a la intolerancia, que en el contexto en el que fueron expresadas no hay tensiones, ni antecedentes históricos en suiza de discriminación de los armenios, que no ha pretendido atentar a la dignidad de los miembros de la comunidad armenia hasta el punto de requerir una respuesta penal, que Suiza no está obligada a ello por ninguna norma del derecho internacional, que los tribunales suizos le han censurado por emitir una opinión divergente de la de la opinión dominante en Suiza, y que la injerencia en su derecho con una condena penal ha sido grave y desproporcionada, no necesaria en una sociedad democrática como la suiza.

Como contraste, el voto particular, firmado por siete de los diez magistrados (Spielmann, Casadevall, Berro, De Gaetano, Sicilianos, Silvis y Kuris) dice prácticamente todo lo contrario: consideran que el genocidio armenio es un hecho histórico claramente establecido y que negarlo es negar la evidencia. Afirman que, al margen de ello, no es esa la cuestión, sino que el problema es si es posible a un Estado penalizar el insulto a un pueblo víctima de un genocidio sin traspasar el margen de apreciación que le corresponde. Reexaminando los cinco pasos argumentados por el voto mayoritario realizan una calificación de los hechos totalmente diferente. Primero, que las afirmaciones de Perinçek se hacen con 
animo de insultar a un pueblo, que contienen una connotación racista denigrante de la memoria de las víctimas del pueblo armenio, como lo han juzgado los tribunales suizos. Que estos últimos han demostrado la motivación de discriminación racial y étnica. Por tanto, la injerencia del gobierno ha sido legítima. Que el demandante conocía bien la legislación penal suiza. Que el artículo 261 bis, $\$ 4$ del código penal suizo en cuanto a su contenido es perfectamente conforme con la Convención Europea y persigue fines legítimos de la protección de derechos de terceros y la defensa del orden. Segundo, en cuanto a la apreciación de los factores geográficos e históricos, afirman que los derechos humanos universales son derechos erga omnes, exigibles en todos los contextos geográficos y por tanto un punto de vista universalista los hace exigibles en todos los países aunque no hayan tenido relación directa con determinados genocidios.

En mi caso, comparto estos argumentos, aunque, a su vez, sin caer en el relativismo considero que en cuanto a las consecuencias concretas de unos hechos sí que se debe tener en cuenta las tensiones reales que genera un discurso racista en cada sociedad dada pudiendo suponer una mayor o menor incitación concreta a la discriminación de grupos o individuos ${ }^{167}$. En cuanto a la calificación del genocidio armenio como genocidio remito a lo que he mantenido a lo largo del artículo, compatible con el hecho de que el gobierno suizo pueda perseguir penalmente genocidios, pero si decide incluir la persecución penal de la masacre armenia debería aclararlo mejor. En cuanto al factor temporal, contraponen el principio de imprescriptibilidad de los crímenes de guerra y los crímenes contra la humanidad. Estoy de acuerdo con la no prescripción, pero el uso del derecho penal a mi juicio debe tener en cuenta la vulneración de víctimas aun vivas o sus antepasados recientes, o una incitación presente al odio de grupos vulnerables hoy y que puedan incidir en su discriminación actual. Para otros temas se pueden usar leyes memoriales, pero no el derecho penal. Es cierto, por otro lado que el voto mayoritario deja en mal lugar al legislador suizo como si hubiera ido más allá de lo exigido por el derecho internacional y si bien he compartido la interpretación de las normas internacionales realizadas por el voto mayoritario, es también cierto que la tendencia de todas las normas va en la dirección de aconsejar la penalización de la justificación de los genocidios reconocidos por tribunales internacionales. Según la opinión disidente de estos 7 jueces, la falta de homogeneidad en las legislaciones sería un motivo para admitir con más razón el margen de apreciación de los Estados. En mi opinión, como hemos visto aun-

167 A mi juicio, me inclino a que debería examinarse habitualmente el peligro real y no el peligro en abstracto, si bien dejamos una discusión más detallada sobre este aspecto para una futura discusión. 
que el derecho común no lo haya impuesto, la tendencia va en esa dirección, no en la contraria. Estos jueces insisten precisamente en esto, que la Decisión Marco de la UE, la recomendación n. ${ }^{\circ} 7$ de la ECRI (ahora también la n. ${ }^{\circ}$ 15), el Comité de Naciones Unidas para la eliminación de la discriminación racial recomienda la criminalización de los discursos negacionistas. El legislador suizo está en su derecho de legislar una norma antirracista penalizando el genocidio, aunque vaya más allá de los mínimos impuestos por el Derecho Internacional. En conclusión, apoyan la ponderación de derechos realizada por el Tribunal Federal suizo. Por su parte, la jueza Nußberg piensa que no ha habido una violación material del artículo 10, pero cree que ha habido una violación procesal en razón de una falta de seguridad por la redacción del artículo 261 bis $\$ 4$ del Código penal suizo, opinando que dicho Estado no ha infringido el art. 10.2 del Convenio Europeo de Derechos Humanos.

Pero todo ello no impediría juzgar si existe una intención racista en este tipo penal o los peligros y las consecuencias de discriminación de ciertas minorías al crear un peligro concreto (peligro concreto, no peligro abstracto, y tampoco clima hostil o adelantar el momento punitivo a un derecho penal preventivo), pero ha de decirse que la frontera es muy difícil. Tan difícil que los propios jueces del TEDH están en la actualidad, como se ha comprobado, muy divididos.

\section{CONCLUSIÓN}

Como conclusión de todo lo estudiado sostenemos que en Europa es conveniente penalizar la negación y justificación del Holocausto nazi, como genocidio reconocido por el Derecho Internacional. Pero ello debería hacerse en el contexto de delitos de discriminación racial contra personas actuales, no sólo en el contexto del mantenimiento de la memoria del pasado. Sería partidaria de limitar este delito de negación yo justificación sólo al Holocausto nazi o como mucho a la negación de genocidios reconocidos por Tribunales Internacionales en el pasado, ya que una norma penal no puede ser una norma abierta que convierta en delito algo que todavía no estaba reconocido en el momento en que la norma entró en vigor. A mi juicio, se debería incluir en el tipo penal tan sólo el negacionismo de los genocidios y excluir el negacionismo de los crímenes contra la humanidad y crímenes de guerra. La negación y/o justificación de otros delitos, como los dos citados y otros discursos racistas podrían encuadrarse dentro de tipos penales de discriminación racista, en caso de que se demuestre esa intención en quien profiere el discurso. 
Además se debería usar el término «genocidio» jurídicamente. De manera que, en puridad, sólo fuera delito la negación y/o justificación de genocidios reconocidos por tribunales internacionales a partir del Tribunal de Nuremberg, que creó este concepto. De manera que no pudiera ser aplicado de manera retroactiva a hechos históricos anteriores sobre los que no exista ninguna calificación de tales por un Tribunal Internacional, siempre refiriéndonos a la penalización de negación o justificación del genocidio. Así deberían quedar fuera de este término a efectos penales, otras masacres o genocidios que puedan ser reconocidos como tales desde el punto de vista histórico, como la matanza o genocidio de armenios realizada por los turcos durante la primera guerra mundial. Una vez más, en estos casos cabe aplicar legislación penal que contemple el delito de infamia u otros tipos penales. Además en esos casos referidos al pasado, los gobiernos y los parlamentos pueden utilizar otros procedimientos jurídicos válidos, como el de legislar sobre leyes memoriales. Pero estas legislaciones no deben tener una finalidad penal, sino de otro tipo. Son además leyes simbólicas, que nadie tienen que ver o no deberían tenerlo con lo específico de los procedimientos penales, en los que se acusa a personas que en el presente cometen delitos de discriminación racial. Por otro lado, para proteger la libertad de investigación de los historiadores, los delitos de negación y/ o justificación del genocidio deben estar bien delimitados con normas penales precisas. Sin embargo, las conductas expresivas realizadas con intención racista, basándose en un falso revisionismo histórico no deben quedar protegidas por el derecho de libertad de investigación y de expresión. Los actuales negacionistas revisionistas buscan denigrar con intención racista a determinados individuos y/o grupos por sus cualidades de pertenencia a una raza, a un grupo étnico, por su origen nacional o su religión.

En el caso de los revisionistas «de mala fe» nos referimos a personas que están cometiendo en la actualidad un delito de discurso racista, y que incitan al odio. Los negacionistas delinquen, mientras que los historiadores profesionales de buena fe no cometen ningún delito (si se legisla adecuadamente y con la precisión necesaria). De hecho, a excepción de los casos relatados sobre Francia, en todos los demás países europeos y en los casos presentados ante el TEDH se trataba de personas racistas y/o neonazis.

Además la legislación penal sobre esta materia debería requerir la intención racista, motivo de incitación de discriminación racial o incitación a la violencia hacia personas o grupos, y la publicidad, basada en la justificación de los genocidios. Bastaría la comisión indirecta de incitación al odio, pero evitando conceptos abstractos, como la creación de clima hostil o la lesión del orden público o la paz social. Este delito debería ser formulado con un tipo especial, pero 
encuadrado en el contexto de otros delitos por discursos racistas que precisan la comisión directa o indirecta de un acto ilícito contra personas.

Entre toda la normativa examinada la más acorde con estas tesis son las Recomendaciones n. ${ }^{\circ} 7$ y n $^{\circ}{ }^{\circ} 15$ de la ECRI. En relación con la jurisprudencia resulta adecuada la del TEDH, pero este último debería realizar en todos los casos una ponderación de los derechos en juego teniendo en cuenta las circunstancias concretas, utilizando el test del principio de proporcionalidad. Con este fin, no debería rechazar la admisibilidad del caso, basándose únicamente en el art. 17 del Convenio Europeo de Derechos Humanos. La normativa del Consejo de Europa y de la UE presenta tanto en su formulación como en su aplicación algunos problemas que ya hemos señalado.

Analizando el marco jurídico que proporciona esta Recomendación n. ${ }^{\circ} 15$ de la ECRI, en conexión con todas las demás Recomendaciones de ese organismo consultivo, que busca encuadrar algunas interpretaciones basadas en el Convenio, en la jurisprudencia del TEDH y en las normas internacionales que ya hemos citado, hemos extraído algunas pautas de actuación que podrían orientar a los legisladores nacionales a la hora de situar el tipo de justificación del genocidio dentro de los delitos de discursos racistas, a fin de formular con mayor precisión los tipos penales.

Por un lado el bien jurídico protegido sería la igual dignidad de cada persona humana, en conjunción con otros derechos como la libertad de expresión y de opinión. En este contexto de actuación penal, se distingue entre el discurso del odio con sus diferentes formas delictivas y la negación del genocidio como un delito encuadrado dentro de los anteriores, pero con un tipo penal específico. El hecho lesivo que se quiere prevenir es la discriminación racial o la lesión de la dignidad de la persona. El Convenio de Derechos Humanos utiliza también como límite en el ejercicio del derecho de libertad de expresión el daño a la reputación de los demás.

Lo que se castiga debería ser la provocación o incitación, en cualquier forma de la denigración, odio o vilipendio de una persona o de un grupo de personas, así como el acoso, insulto, estereotipar, estigmatizar o amenazar a esa persona o ese grupo de personas y justificar ese tipo de manifestaciones, por discriminación basada en la raza, el color, el origen nacional o étnico, religión o creencia. Criterios casi todos ellos contemplados en los Tratados Internacionales, el Derecho de la UE y del Consejo de Europa, que hemos descrito detalladamente. La incitación debe estar dirigida a cometer actos de violencia, intimidación, hostilidad y discriminación contra aquellos que son objeto del mismo y se debe asegurar que es una forma seria de discurso.

El titular de la dignidad son las personas concretas individualmente o en grupo, pero en cuanto que cada uno de ellos posee una dignidad. No se contem- 
pla un derecho colectivo o una titularidad colectiva, aunque las demandas puedan ser accionadas colectivamente. En este sentido entendería que se otorga tutela a un daño que se pueda probar de vejación o humillación de uno varios individuos que son lesionados en su dignidad. La acción penal contra conductas racistas tiene como objetivo proteger a los individuos y a los grupos, pero no a la creencias, a las ideologías o las religiones. Por eso las formas de expresión crítica de ideas está protegida por el derecho de libertad de expresión, también las que ofendan, choquen o inquieten.

En cuanto al ilícito penal no se deriva de una mera conducta, sino que debe causar actos de violencia, intimidación, hostilidad o discriminación. Lo que se miden son sus efectos. Por otro lado la incitación es a «realizar actos concretos». En ningún momento se usa la palabra «clima hostil o clima de odio». El contexto publico es un requisito esencial cuando se recomienda que las sanciones penales sean impuestas en ciertos usos del discurso del odio cuando esto interfiere con la libertad de expresión. De manera que la conductas expresivas privadas de discriminación racial pueden tratarse con otros medios jurídicos, como la vía civil o las sanciones administrativas, pero no sería apropiado crear tipos penales.

Siguiendo con mi propia interpretación, se deriva que la recomendación no anima a penalizar palabras que impliquen una peligrosidad abstracta, sino como mucho una peligrosidad potencial o hipotética y/o una peligrosidad concreta. Por tanto, no se esta recomendando a los Estados adelantar la barrera punitiva. Para medir si hay riesgo de que se produzcan esos actos hay que tener en cuenta las circunstancias específicas en el que se produce el discurso. En mi opinión, el juez debe hacer una valoración del contexto social y se debe probar la conexión casual entre el discurso emitido y sus efectos, así como probar el resultado lesivo, el riesgo y la peligrosidad.

Se caracteriza como una forma especial de discurso del odio los supuestos en los que dicho discurso adquiera la forma de una negación pública, trivialización, justificación o condonación del crímenes de genocidio, crímenes contra la humanidad o crímenes de guerra, cuya existencia haya sido reconocida por los tribunales, y la glorificación de las personas condenadas por haber cometido tales crímenes. Aplicando las características indicada a esta justificación de crímenes de genocidio, para calificarlas como delitos de odio (de discriminación racial), deben responder a la intencionalidad de denigrar o estigmatizar a personas o grupos actuales por razón de su raza, religión nacionalidad o por su origen étnico etc. La criminalización de este discurso está relacionado con su objetivo, que es herir a individuos o grupos. De lo que se deriva que debe haber incitación o provocación de denigrar a personas o grupos, que se exige dolo con intención 
racista y que el discurso se realice de modo público. El contenido del injusto es que se genere un peligro cierto de actos ilícitos contra las personas o grupos.

Otras dos características que deben confluir para dar lugar a delito de discurso de odio es que ese discurso refleje o promueva una asunción injustificada de que quien lo emite se considera superior a una persona o a un grupo que son objeto de esa crítica. Además ese discurso debe tener como intención el incitar o esperar razonablemente el efecto de incitar a otros a cometer actos de violencia, intimidación, hostilidad o discriminación contra quienes va dirigido el discurso crítico, ya que de este modo esto constituye una forma especialmente seria de discurso de odio. Es decir, el elemento de incitación implica que exista una clara intención de incitar a cometer actos de esos tipos, o un riesgo inminente de que esos actos ocurran a consecuencia de ese particular discurso de odio utiliza$\mathrm{do}^{168}$. No se especifica si la incitación es directa o indirecta.

En este marco jurídico, se explicita un delito con tipo especial que tendría lugar en la forma de negación pública, trivialización, justificación o condonación de los crímenes de genocidio, crímenes contra la humanidad o crímenes de guerra (retomado la recomendación n. ${ }^{\circ} 7$ de la ECRI). Esos genocidios deben de haber sido reconocidos por los tribunales, sin especificar aquí de qué tipo de tribunales se trata (siguiendo el Convenio de Cibercriminalidad que admite los naciones e internacionales). Todas esas conductas descritas para ser delictivas deben haber sido realizadas con un fin racista y/o discriminatoria.

En la otra cara de la moneda se sitúa la defensa de la libertad de expresión y el peligro de que la penalización de determinadas conductas como delitos de odio puedan ser usadas por los gobiernos para suprimir cualquier libertad de crítica en la sociedad o silenciar a las minorías o de crítica política o de crítica de las creencias. A su vez la libertad de expresión protege discursos que pueden ofender, chocar o herir.

Title:

The Denial or Justification of Genocide as a Criminal Offense in European Law. A proposal taking in account the Recommendation number 15 of the ECRI.

${ }^{168} C f r$, Explanatory Memorandum, n. ${ }^{\circ} 14$. 


\section{Summary:}

I. Introduction. II. Law and its Relation to the History: similarities and differences. Simple or neutral Denial versus the qualified Denial. III. Revisionist Denial should not be protected by the Right to Freedom of Expression and Freedom of Research. IV. The Definition of Genocide in the United Nations Legal Instruments and its Difference with Crimes against Humanity. V. UE Regulations. VI. The Legal Framework in the Council of Europe. The Convention on Cybercrime, concerning the Criminalisation of Acts of a racist and xenophobic $\mathrm{Na}$ ture committed through Computer Systems and its Additional Protocol. VII. Some Problems of Interpretation of the Council of Europe and UE Legislation. The non-Requirement to prove the racist Intent in the Council of Europe Convention on Cybercrime. VIII. The Test of racist Intent. IX. The Requirement of racist Intent and Publicity in the General Policy Recommendation n. 7 of ECRI. X. The Definition of Denial as a Form of Hate Speech in ECRI's General Policy Recommendation n. ${ }^{\circ}$ 15. XI. The Criterion seated by the ECtHR: legitimate Debate of Ideas and the clearly established historical Facts. XII. The ECtHR, Freedom of Expression and its Limits. XIII. Article 17th of the European Convention on Human Rights. The Danger of non application of Proportionality Principle. XIV. The Balance of Rights in the Case Perinçek v. Switzerland. XV. Conclusion.

\section{Resumen:}

En este artículo se analiza la normativa de la UE y del Consejo de Europa, así como la jurisprudencia del TEDH, sobre la penalización de la negación o justificación de los genocidios, concretamente del Holocausto de los judíos a manos de los nazis en la II Guerra Mundial. A la vista de la creciente oleada de partidos neonazis y de la violencia nazi en otros ámbitos, como el del futbol, se concluye que es pertinente la inclusión de la penalización de la justificación del genocidio nazi en los códigos penales europeos, cuando ésta se realiza con intención racista y con ánimo de reinstaurar en el presente prácticas similares o de incitar públicamente a la discriminación y a usar la violencia contra personas por razón de su raza, religión o por su origen nacional o étnico. Examinada la legislación existente en el ámbito del derecho internacional europeo se señalan algunas de sus deficiencias y se propone unas pautas de lege ferenda, en la línea de lo indicado en las Recomendaciones n. ${ }^{\circ} 7$ y n. ${ }^{\circ} 15$ de la ECRI, que no son textos normativos, sugiriendo en opinión de la autora que el delito debería reducirse a la justificación del Holocausto nazi, según la jurisprudencia sentada en el Tribunal militar de Nuremberg, establecido por el 
Acuerdo de Londres del 8 de abril de 1945, o como mucho estrictamente a los genocidios reconocidos por Tribunales Internacionales, y que el tipo penal no debería hacerse extensivo ni a los crímenes contra la humanidad, ni a los crímenes de guerra. Se apunta que el término «genocidio», en relación con la penalización de su justificación en la actualidad, debería usarse según su concepción jurídica, referida sólo a los genocidios declarados como tales por Tribunales Internacionales, a partir del Tribunal de Nuremberg, de manera que el delito penal de negacionismo y/o justificación de genocidio no debiera ser aplicado a hechos históricos anteriores a esa fecha. Por un lado el bien jurídico protegido sería la igual dignidad de cada persona humana, en conjunción con otros derechos como la libertad de expresión y de opinión. En este contexto de actuación penal, las recomendaciones de la ECRI distinguen entre el discurso del odio con sus diferentes formas delictivas y la negación del genocidio como un delito encuadrado dentro de los anteriores, pero con un tipo penal específico. El hecho lesivo que se quiere prevenir es la discriminación racial o la lesión de la dignidad de la persona. Se sugiere que los discursos de negación y/o justificación del genocidio se afronten dentro de los delitos de discriminación racial y se consideren como una forma especial de discurso del odio los supuestos en los que dicho discurso adquiera la forma de una negación pública, trivialización, justificación o condonación del crímenes de genocidio, cuya existencia haya sido reconocida por los tribunales, debiendo responder a la intencionalidad de denigrar o estigmatizar a personas o grupos actuales por razón de su raza, religión nacionalidad o por su origen étnico u nacional. La criminalización de este discurso está relacionado con su objetivo, que es herir a individuos o grupos. De lo que se deriva que debe haber incitación o provocación de denigrar a personas o grupos, que se exige dolo con intención racista y que el discurso se realice de modo público. El contenido del injusto es que se genere un peligro cierto de actos ilícitos contra las personas o grupos.

Otras dos características que deben confluir para dar lugar a delito de discurso de odio es que ese discurso refleje o promueva una asunción injustificada de que quien lo emite se considera superior a una persona o a un grupo que son objeto de esa crítica. Además ese discurso debe tener como intención el incitar o esperar razonablemente el efecto de incitar a otros a cometer actos de violencia, intimidación, hostilidad o discriminación contra quienes va dirigido el discurso crítico, ya que de este modo esto constituye una forma especialmente seria de discurso de odio. 


\section{Abstract}

In this paper are analyzed the rules of the EU and the Council of Europe and the jurisprudence of the ECHR, on criminalization of denial or justification of genocide, specifically the Holocaust of the Jews to the Nazis in the Second War World. In view of the rising of neo-Nazi parties and Nazi violence in other areas, such as football, it is concluded that it is appropriate to include the criminalization of justification of Nazi genocide in the European criminal codes, when this is done with racist intent and seeking to reopen these similar practices or publicly inciting to discrimination or to use violence against people because of their race, religion or national or ethnic origin. It is examined existing legislation in the field of international and European law and it has been identified some of its deficiences and it is proposed some guidelines as lege ferenda in line as they are indicated in the Recommendation No. 7 of the ECRI, which is not a legislative text, suggesting according to the author's opinion that the criminal offense of negationism of genocide should be reduced to the justification of the Nazi Holocaust, according to the jurisprudence of the Nuremberg military Tribunal, established by the London Agreement of 8 April 1945, or at most strictly to the genocides recognized by International Courts, and that the crime should not be extended to the crimes against humanity or war crimes. Finally, it is noted that the term "genocide» in relation to the criminalization of their justification nowdays, should be used as a legal concept, referred only to genocide declared as such by international tribunals, since the $\mathrm{Nu}$ remberg Tribunal, so that the criminal offense of denial of genocide should not be applied to previous historical events before that date. On the one hand, the legally protected good would be the equal dignity of every human person, in conjunction with other rights such as freedom of expression and opinion. In this context of criminal proceedings, the recommendations of the ECRI distinguish between hate speech with different forms of crime and genocide denial as a crime framed within the previous, but with a specific offense. The wrongdoer that wants to be prevented is racial discrimination or injury to the dignity of the person. It is suggested that discourses of denial and / or justification of genocide will be addressed within the crimes of racial discrimination and considered as a special form of hate speech cases in which such discourse takes the form of a public denial, trivialization, justification or condoning crimes of genocide, whose existence has been recognized by the courts. It must respond also to the intention of denigrating or stigmatizing individuals or current groups because of their race, religion, nationality or ethnic 
or national origin. The criminalization of this speech is related to its objective, which is hurting individuals or groups. What follows is that there must be incitement or provocation to denigrate individuals or groups, which requires willful misconduct with racist intent and that the speech is made in public. The content of the unjust is that a certain danger of unlawful acts against persons or groups is generated. Two other features that must come together to give rise to crime of hate speech is that speech reflects or promotes an unjustified assumption that emits who is considered superior to a person or a group who are subject to that criticism. Besides that speech shall be intended to incite or reasonably expect the effect of inciting others to commit acts of violence, intimidation, hostility or discrimination against those targeted by the critical discourse, since so this is a particularly serious form of speech of hate.

\section{Palabras claves:}

Definición de genocidio, delito de justificación del genocidio, Decisión marco de la UE, Convenio sobre Cibercriminalidad del Consejo de Europa, ECRI, Jurisprudencia del TEDH, verdad histórica y hechos históricos reconocidos por los tribunales.

\section{Key Words:}

Definition of Genocide, Crime of Denial and/or Justification of Genocide, EU legislation, Convention on Cybercrime of the Council of Europe, ECRI Recommedation n. ${ }^{\circ} 15$ on combating hate speech, ECHR jurisprudence, historical truth and historical facts recognized by the courts decisions. 